\title{
Efficiency and equity effects of social grants in South Africa
}

SERVAAS VAN DER BERG, KRIGE SIEBRITS AND BONGISA LEKEZWA

\section{Stellenbosch Economic Working Papers: 15/10}

KEYWORDS: SOCIAL SECURITY, SOCIAL GRANTS, SOCIAL PENSIONS, CHILD SUPPORT GRANTS, EFFECTS OF SOCIAL GRANTS, SOUTH AFRICA

JEL: H31, H53, I38

SERVAAS VAN DER BERG DEPARTMENT OF ECONOMICS UNIVERSITY OF STELLENBOSCH PRIVATE BAG X1, 7602 MATIELAND, SOUTH AFRICA E-MAIL: SVDB@SUN.AC.ZA
BONGISA LEKEZWA DEPARTMENT OF ECONOMICS UNIVERSITY OF STELLENBOSCH PRIVATE BAG X1, 7602 MATIELAND, SOUTH AFRICA E-MAIL:

15272354@SUN.AC.ZA

KRIGE SIEBRITS DEPARTMENT OF ECONOMICS UNIVERSITY OF STELLENBOSCH PRIVATE BAG X1, 7602 MATIELAND, SOUTH AFRICA E-MAIL: KRIGESIEBRITS@SUN.AC.ZA BUREAU FOR ECONOMIC RESEARCH AT THE UNIVERSITY OF STELLENBOSCH 


\title{
Efficiency and equity effects of social grants in South Africa ${ }^{1}$
}

\author{
SERVAAS VAN DER BERG, KRIGE SIEBRITS AND BONGISA LEKEZWA
}

\section{ABSTRACT}

This paper discusses the nature and effects of social grants programmes in South Africa against the backdrop of international trends in the reform of social assistance systems. It shows that South Africa has a well-developed social assistance system that significantly reduces extreme poverty, in part because the grants are very well targeted. The review of existing literature and new evidence presented in this paper suggest that the grants influence the behaviour of recipients and potential recipients in various ways, not all of which are necessarily benign. The paper also highlights the scope for further research on the potential of workfare programmes, conditional cash transfer programmes and other innovative social assistance schemes in the South African context.

Keywords: Social security, social grants, social pensions, child support grants, effects of social assistance, South Africa

JEL codes: H31, H53, I38

\footnotetext{
1 This document was prepared for the Financial and Fiscal Commission (FFC) as one of the technical papers that supported the Commission's recommendations on the division of revenue among the three spheres of government in the 2010/11 financial year. We are grateful to the Commission for funding the research and for permission to make the document available in this format. The FFC published an abridged version of the document as chapter 3 of the Technical report: Annual submission on the division of revenue 2010/11, which is available on its website (http://www.ffc.co.za/docs/). It should be noted that the paper is reproduced here as submitted to the FFC in January 2009 with editorial changes only. Some of the information provided on aspects of the South African social security framework no longer is up to date.
} 


\section{Efficiency and equity effects of social grants in South Africa}

\section{INTRODUCTION}

Social security systems provide protection against risks of income loss due to contingencies such as old age, unemployment, disability, and injuries sustained at work. As such, they play an important consumption-smoothing role by redistributing income across time. Apart from this function, social security systems also redistribute income between generations and amongst the insured according to risk and vulnerability. Social security systems typically consist of three parts: ${ }^{2}$

- $\quad$ Social insurance: benefits organised by the state and funded by means of specified contributions by employers and employees

- $\quad$ Social assistance (grants): non-contributory cash or in-kind grants to provide protection to the most needy

- Informal insurance: cash or in-kind assistance from the extended family and other social networks

Despite being a middle-income country, South Africa has an extensive formal social security system with many of the trappings of a modern welfare state. This paper focuses on the social assistance part of the system, which is particularly well developed by international standards. Section 2 outlines the evolution, present nature and coverage and aspects of the institutional framework of the social security system in South Africa. Section 3 discusses the role and economic effects of social grants in other countries, as well as broad currents in the reform of social assistance systems Particular attention is given to workfare programmes in OECD countries and conditional cash transfer programmes in Western Hemisphere developing countries. Against this background, Section 4 surveys existing literature on the efficiency and equity effects of social grants in South Africa, while Section 5 presents new empirical evidence on aspects of these effects. Section 6 concludes the paper.

\section{SOUTH AFRICA'S SOCIAL SECURITY FRAMEWORK}

\section{2(a) History of social security in South Africa ${ }^{3}$}

The origins of the South African social security system should be sought in attempts to create a welfare state for whites during the apartheid era. The objective was to protect whites against various contingencies by means of social insurance and, when that failed, social assistance (social old-age pensions, for example, protected elderly whites with inadequate private pension income from indigence).

\footnotetext{
${ }^{2}$ Social security systems often are complemented by other social programmes such as education and training programmes, health insurance schemes, specialised care facilities and protective labourmarket policies. These programmes fall outside the scope of this paper.
}

${ }^{3}$ This section draws on Van der Berg (1997) and Van der Berg (2002). 
The first pension fund in South Africa was established in the South African (Transvaal) Republic in 1882 . The earliest pension funds were not prescribed by legislation or by convention; as such; they did not represent social insurance. In the 1920s, however, many skilled (mainly white) employees obtained occupational retirement insurance. Binding industrial-council and other agreements between employers and employees eventually introduced an element of compulsion into many occupational insurance schemes, thus turning them into quasi-social insurance schemes. ${ }^{4}$ The Pensions Funds Act of 1956 was a major milestone as far as regulation of the financial responsibilities of pension funds is concerned. The norm of excluding less-skilled workers from coverage remained, however; in the apartheid context, this meant that almost all blacks were excluded. Occupational retirement insurance was expanded to less-skilled workers only in the 1960s and early 1970s, when rapid industrialisation increasingly drew black workers into industry. The total membership of occupational and private retirement funds increased from 923000 in 1958 to 9309000 in 1993 - an average annual growth rate of almost 7 percent over a period of more than three decades (Smith Committee, 1995: D2.4a). ${ }^{5}$ Some industries (such as agriculture, domestic service, and trade, catering and accommodation) nonetheless remained poorly covered. The majority of the black labour force remained outside the formal social insurance net, either because of unemployment or because they occupied jobs not covered by social retirement insurance.

Various racially differentiated social grants were introduced between 1910 and 1950, including military pensions (1919), social pensions (1928), grants for the blind and the disabled (1936 and 1937), pensions for war veterans (1941) and family allowances for large poor families (1947). Protection against unemployment remained comparatively underdeveloped, because job reservation and higher education and skill levels assured most whites of employment since the time of the Great Depression. The institution that was established to do so, the Unemployment Insurance Fund (UIF), only provided cover against cyclical unemployment, which was usually mild and of relatively short duration. State welfare expenditure helped to maintain white support for the apartheid regime. By comparison, the safety net for other groups initially was rudimentary. The grants were progressively extended to other population groups over time, however, albeit initially at much lower benefit rates.

A major impetus for social reform from the early 1970s onwards came from attempts to legitimise the homeland system and the tricameral parliament (which consisted of white, coloured and Indian chambers). Attempts at co-option led to rapid growth in the amounts flowing to the homelands and subsequently, albeit even before the establishment of the tricameral parliament in 1983, to the coloured and Indian communities. The fiscal costs of incorporating the relatively small coloured and Indian groups into a welfare society were not too great a burden on the budget, though this coincided with other events that also contributed to fiscal stress.

\footnotetext{
${ }^{4}$ In South Africa, unlike in many other countries, contributions paid by employers and employees are not included in social security taxes, because they do not flow through the coffers of the state. International comparisons of the extent of social security provision based on government spending ratios therefore misrepresent the scope of insurance provision in South Africa.

${ }^{5}$ These figures reflect extensive duplication, because many South Africans belong to more than one fund.
} 
The far greater fiscal challenge, namely full incorporation of blacks into the system and elimination of the racial barriers that had allowed the welfare state for whites to flourish, was postponed. Only in the latter part of the 1980s did the government commit itself to eliminating racial differentials in benefit structures of all social programmes. Fiscal constraints, however, meant that the equalisation of benefit levels could be achieved only by combining decreases in the real value of the maximum social pension received by whites with increases in that received by blacks. This was most readily accomplished in areas where resistance to reducing white benefit levels was weakest. One notable example was means-tested social old-age pensions, because relatively poor elderly whites were a small and politically marginal group whose benefits could be reduced with little fear of political backlash. By 1993 the pension gap had been closed completely and discrimination in the application of the means test had been eliminated, with all groups receiving roughly the same real grant level per beneficiary as was received previously by coloureds and Indians (see Figure 1).

Figure 1

Real value of the maximum annual social pension (1979-2003)

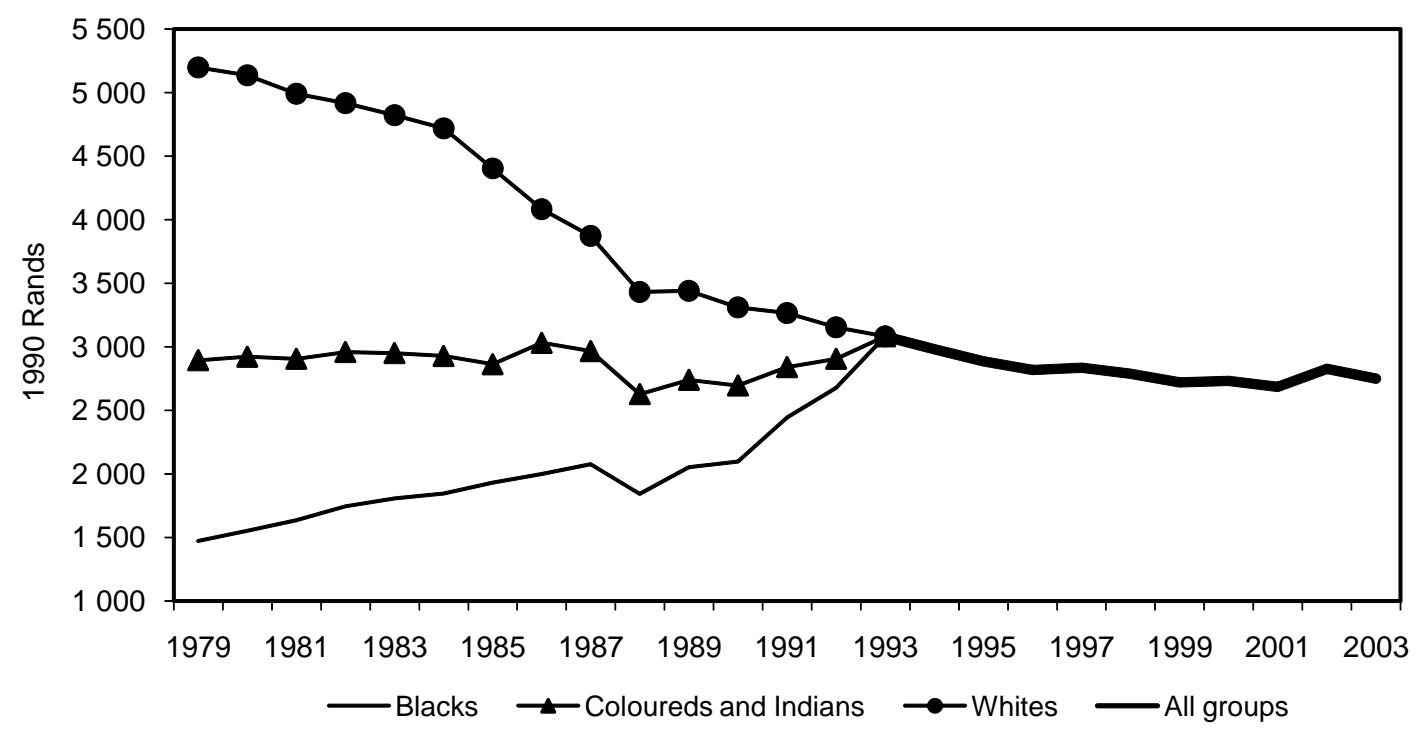

The equalisation of benefits, introduction of the child support grant in April 1998 and rapid growth in take-up of disability and foster-care grants led to sharp increases in government spending on social assistance grants from the late-1980s onwards. Figure 2 shows general government spending on social protection (which includes outlays by the contributory social funds and grants expenditure by government departments) as percentages of general government outlays and gross domestic product (GDP). General government spending on social protection increased from 6.2 percent of total outlays in 1982/83 to 13.4 percent in 2005/06 (i.e. from 1.8 percent to 4.4 percent of GDP). ${ }^{6}$

The number of beneficiaries of social grants increased from 2.4 million in April 1998 to a projected 12.4 million in 2008 (cf. Table 1). Projections published by the National Treasury (2008: 96) in February 2008 suggested that 66.6 percent of all grants paid

\footnotetext{
${ }^{6}$ The sharp spike in both ratios in 1993/94 reflected a special transfer of R7 340 million to the Government Employees Pension Fund.
} 
in April 2008 would have been child support grants; other large categories would have been old-age pensions (17.9 percent), and disability grants (11.4 percent). Although all the grant types except the war veteran grant and grant-in-aid experienced significant growth in beneficiary numbers during the past decade, the child support grant clearly was the major driver of such growth in the system as a whole. Because it is the smallest of the grants in rand terms, however, the child support grant does not dominate social assistance expenditure. ${ }^{7}$ The 2008/09 Budget provides for social assistance expenditure of R70.7 billion, of which R26.4 billion is allocated for old-age pensions, R21.6 billion for child support grants, R17.7 billion for disability grants and R5.0 billion for other grants (National Treasury, 2008: 319).

Figure 2

General government spending on social protection (1983/84-2005/06)

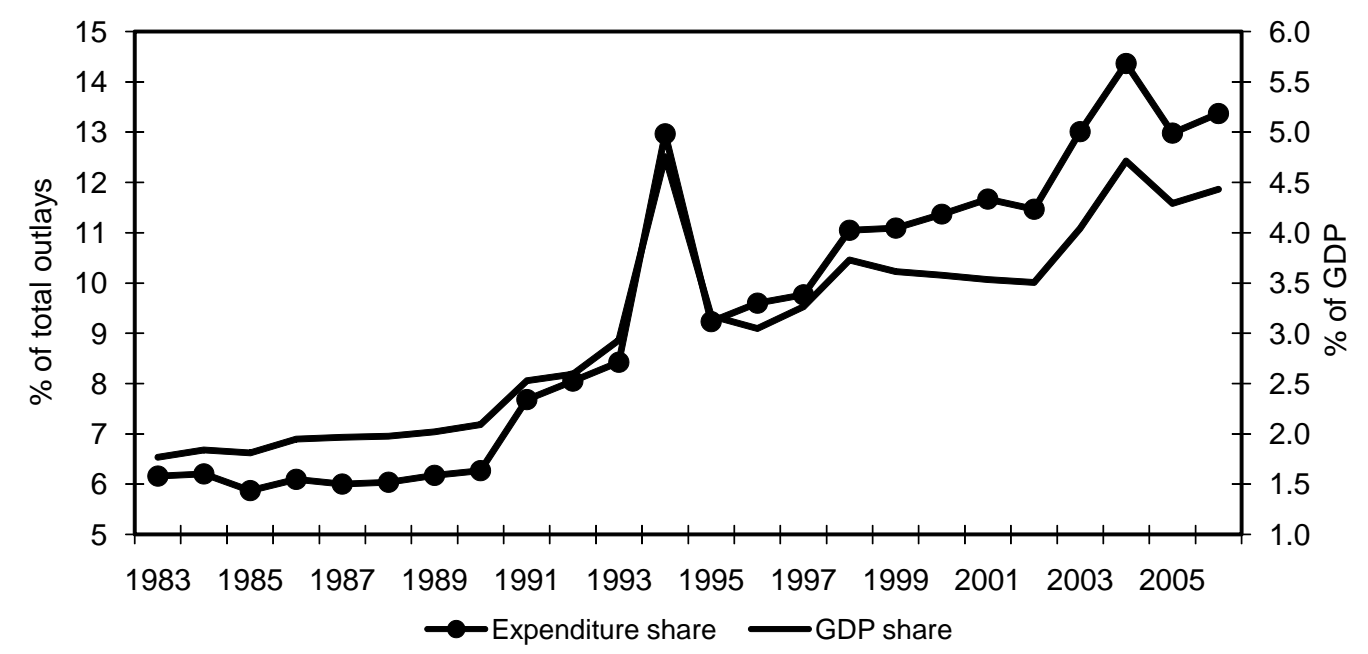

Source: South African Reserve Bank Quarterly bulletins (various issues)

Table 1

Beneficiaries of social assistance grants (1998-2008)

\begin{tabular}{lrrr}
\hline Grant & \multicolumn{3}{c}{ Number of beneficiaries } \\
& 1998 & 2003 & $2008^{1}$ \\
\hline Old age & 1697725 & 2009419 & 2225354 \\
War veterans & 10525 & 4594 & 1931 \\
Disability & 660528 & 953965 & 1409434 \\
Grant-in-aid & 9183 & 12787 & - \\
Foster care & 43520 & 138763 & 446994 \\
Care dependency & 8172 & 58140 & 110153 \\
Child support & - & 2022206 & 8208334 \\
\hline Total & 2429653 & 5808494 & 12402200 \\
\hline Source: & National Treasury Budget review (various issues) \\
Note: & 1 Projections made in February 2008 &
\end{tabular}

\footnotetext{
${ }^{7}$ Section 2(b) provides more detail on the current monthly values of the various grants.
} 
Its apartheid-era roots therefore influenced the South African social security system in at least two important ways. First, the general extension of a system that initially was created to provide comprehensive protection for a segment of the population rendered South African social assistance unusually comprehensive for a middleincome developing country. Second, the system's initial focus on the particular needs of whites (for whom unemployment historically was not a major risk), made it inadequate for an economy in which structural unemployment became a crucial problem.

\section{2(b) The existing social security system}

The insurance component of the South African social security system consists of three contributory social security funds that provide conditional income support or compensation for defined-risk events (the Unemployment Insurance Fund, the Compensation Funds, and the Road Accident Fund) and - in the indirect sense explained in Section 2(a) - a large number of occupational pension schemes. Figure 3 shows that the consolidated social security funds generally have been in surplus in recent years. The Compensation Funds and the Unemployment Insurance Fund have achieved cash-flow surpluses since 1999/00 and 2001/02, respectively, but the Road Accident Fund has remained deficit-ridden.

Figure 3

Cash-flow of the social security funds (1991/92-2007/08)

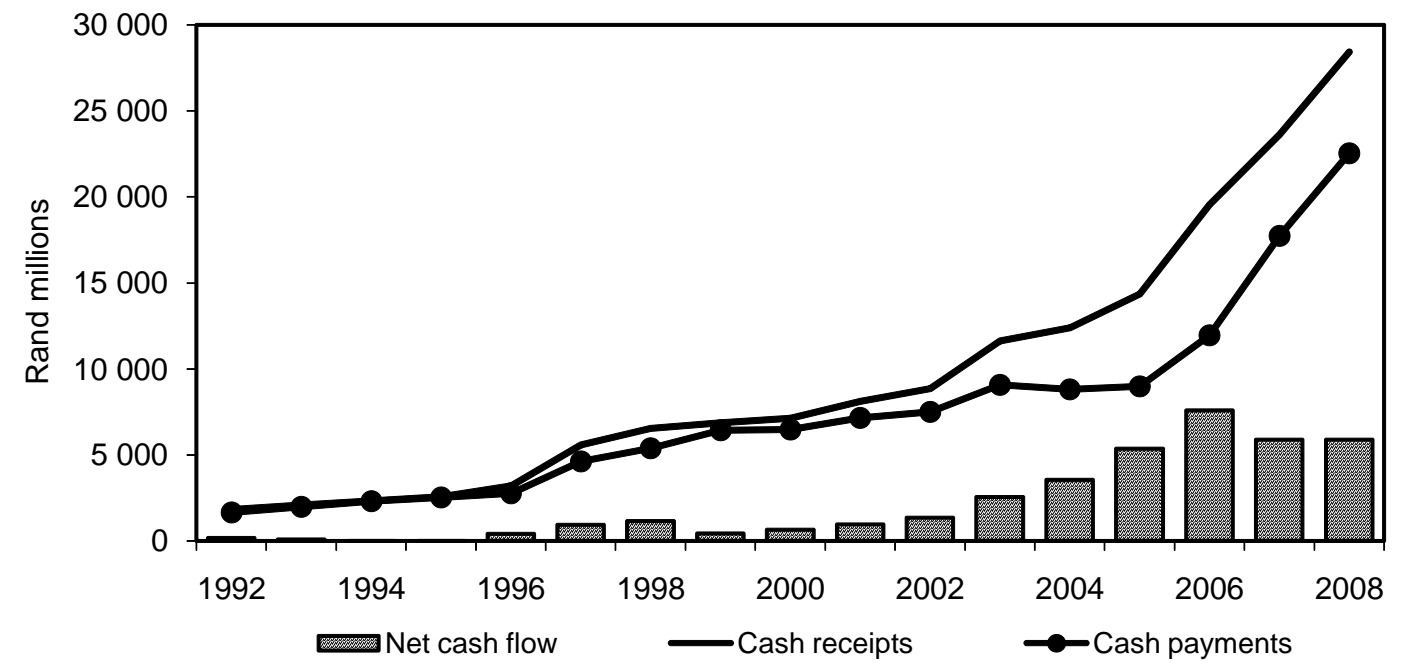

Source: South African Reserve Bank Quarterly bulletins (various issues)

As was indicated in Section 2(a), the number of recipients of social assistance grants increased rapidly during the past few years. The estimated 12.4 million beneficiaries in April 2008 represented more than one quarter of the South African population - a figure unmatched by any other developing country. Social assistance spending in South Africa, which amounted to 3.5 percent of GDP in 2006, is high even when compared to that of Western European countries at the height of the welfare state in 1980. Of the countries shown in Figure 4, only Denmark had a higher social assistance expenditure ratio than is presently the case for South Africa. South Africa's government spending on social grants exceeds the GDPs of 88 countries, including some 35 African countries. 
Figure 4

Social assistance spending as \% of GDP (Western Europe 1980; SA 2006)

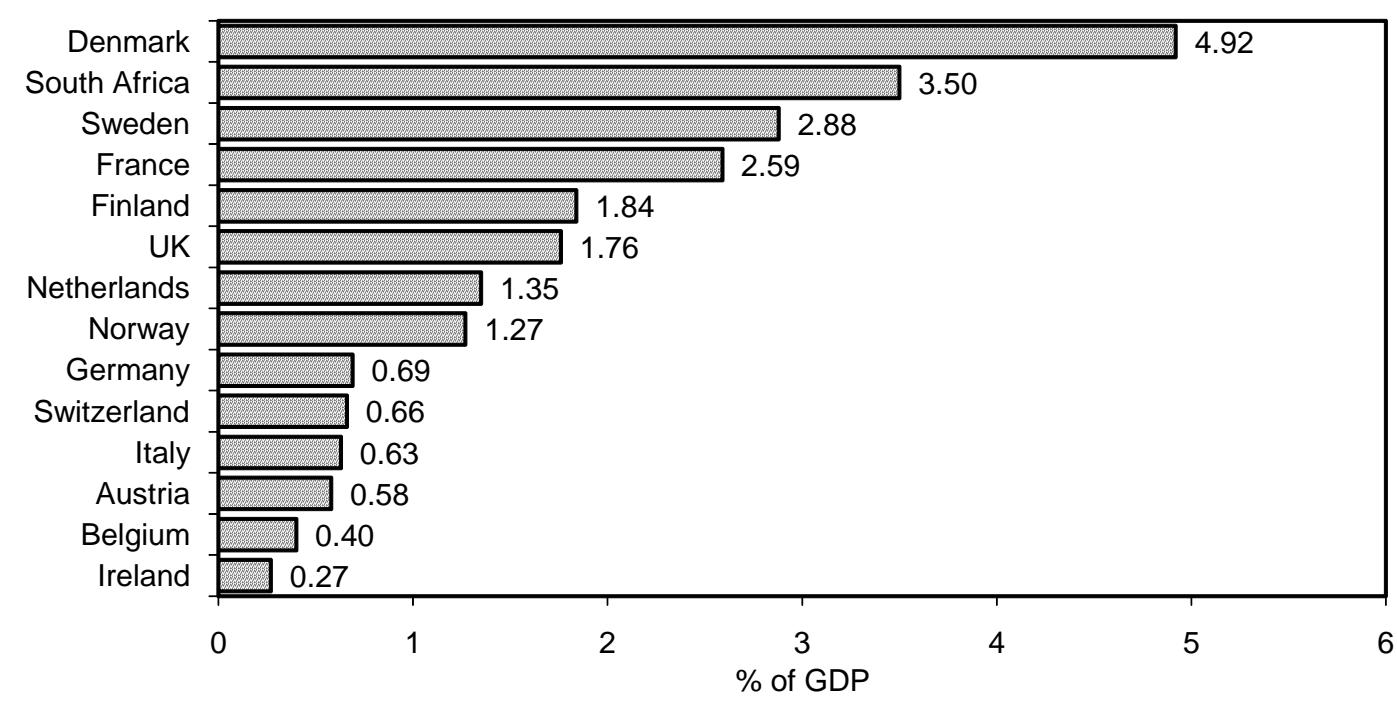

One way to outline the scope of South African social security system is to compare it to those of the advanced welfare states. The "life course framework", which is associated with northern European social protection systems, includes interventions for each of the life stages of individuals and families (cf. Table 2). Contributory programmes and universal tax-financed benefits dominate such systems; by comparison, the targeted social assistance components are small. Targeted programmes, however, play an important residual role by assisting those not reached by other elements of social security programmes (De Neubourg, Castonguay and Roelen, 2007: 9-13).

Table 2

A life course social security framework

\begin{tabular}{|c|c|c|c|}
\hline Age $0-16$ & Age $16-24$ & Age $24-60$ & Age $61+$ \\
\hline $\begin{array}{l}\text { Universal child } \\
\text { allowances }\end{array}$ & $\begin{array}{l}\text { Educational } \\
\text { allowances }\end{array}$ & $\begin{array}{c}\text { Income loss } \\
\text { insurance } \\
\text { Means-tested social } \\
\text { assistance }\end{array}$ & $\begin{array}{c}\text { Universal pensions } \\
\text { Compulsory } \\
\text { contributory pensions } \\
\text { Contributory } \\
\text { survivors' pensions } \\
\text { Means-tested social } \\
\text { assistance }\end{array}$ \\
\hline Disability allowances & Disability allowances & Disability allowances & Disability allowances \\
\hline
\end{tabular}

Source: De Neubourg, Castonguay and Roelen (2007)

Table 3 lists most aspects of the South African social security system in a related but adapted framework. ${ }^{8}$ South Africa relies much more heavily on means-tested social assistance grants than the advanced welfare states; contributory social insurance

\footnotetext{
${ }^{8}$ Two elements are omitted from the table: compensation paid to victims of road accidents by the Road Accident Fund, and temporary grant-in-aid relief payments.
} 
and universal social assistance programmes, on the other hand, are relatively less well developed in South Africa. The remainder of this section discusses the various elements of the South African social security system in more detail.

Table 3

Elements of the South African social security framework

\begin{tabular}{ccc}
\hline Childhood & Working age & Old age \\
\hline $\begin{array}{c}\text { Means-tested child support } \\
\text { grants }\end{array}$ & $\begin{array}{c}\text { Work-related injury } \\
\text { compensation }\end{array}$ & $\begin{array}{c}\text { Means-tested social } \\
\text { pensions }\end{array}$ \\
$\begin{array}{c}\text { Means-tested care } \\
\text { dependency grants }\end{array}$ & $\begin{array}{c}\text { Means-tested disability } \\
\text { grants }\end{array}$ & $\begin{array}{c}\text { Means-tested war } \\
\text { veterans' grants }\end{array}$ \\
Foster care grants & $\begin{array}{c}\text { Temporary unemployment } \\
\text { benefits }\end{array}$ & Occupational pensions \\
\hline
\end{tabular}

\section{Childhood}

The child support grant, which was introduced in April 1998 to replace the child maintenance grant, currently is the most important form of assistance for children in poor families. These grants initially were paid to the primary caregivers of children under the age of seven years, but the coverage of the programme was extended gradually and from January 2009 it will cover children until their fifteenth birthday. ${ }^{9}$ This expansion of the programme, coupled with rapid growth in the take-up rate in the new millennium, contributed to the sharp increase in the number of beneficiaries to an estimated 8208334 in April 2008 (see Table 1). According to the Department of Social Development (Rakoloti, 2008), recent changes to the means test that determines eligibility for the child support grant are likely to increase the number of beneficiaries by a further 1 million, that is, by about 12 percent. $^{10}$

The monthly value of the child support grant initially amounted to R100. Pauw and Mncube (2007: 18-19) showed that its real value decreased until 2000, but increased fairly rapidly thereafter. Following increases of R10 per month on 1 April 2008 and 1 October 2008, the grant now amounts to R230 per month.

Care dependency grants are paid to the parents or caregivers of children between the ages of 1 and 18 years who suffer from severe physical and mental disability and are in permanent home care. (Disabled persons between the ages of 18 and the retirement age receive state disability grants.) In April 2008 these grants, which now amount to R940 per month, were paid to an estimated 110153 care-dependent children. The regulations announced on 30 May 2008 provide for a changed means test for care dependency grants similar to that for child support grants.

The beneficiaries of foster care grants are children deemed in need of care by the courts. Such children are placed in the custody of foster parents designated by the courts and supervised by social workers. The aim of the grant is to reimburse the foster parent or parents for the cost of caring for children who are not their own; as

\footnotetext{
${ }^{9}$ Resources permitting, the Government intends to increase the qualification age limit for the child support grant up to the eighteenth birthday in the medium term (Skweyiya, 2008).

${ }^{10}$ Section 2(c) discusses the mean tests for the various social grants in more detail.
} 
such, the grant is not means tested and falls away if the child is adopted formally. Foster care grants now amount to R650 per month, and in April 2008 were paid to the foster parents of 446994 children.

\section{Working age}

It is well known that South Africa suffers from exceptionally high unemployment that is largely of a structural nature. Statistics South Africa's (2008b) Labour force survey for the first and second quarters of 2008 reported an unemployment rate of 23.5 percent in the second quarter, which implies that almost 4.2 million members of the labour force were unemployed at the time of the survey. The role of the Unemployment Insurance Fund (UIF) therefore is particularly important. Employees and employers each contribute 1 percent of the employee's monthly earnings up to a threshold of R12 478 to the UIF, and the proceeds are used to pay benefits to contributors or their dependents in instances of unemployment, illness, death, maternity and adoption of a child. The amended Unemployment Insurance Act of 2003 changed the coverage and benefits of the UIF in important ways:

- $\quad$ Coverage was extended to include domestic and seasonal workers.

- $\quad$ Coverage was extended to include employees earning more than the specified earnings ceiling (but contributions and benefits were capped at this level).

- A graduated income replacement rate was introduced (the rate ranges from 60 percent for low-income earners to 38 percent for higher-income earners).

- A limit on benefits accrual to 238 days in a four-year period was introduced.

- $\quad$ Contributors resigning voluntarily from jobs were excluded from benefits.

These reforms have had important ramifications for the Fund. The extension of coverage to employees earning more than the specified earnings ceiling implied incorporation of a group whose contributions are large relative to their risks of unemployment; this should improve the solvency of the UIF and enhance its redistributive impact. Although it has strengthened redistribution within the UIF, the introduction of differentiated replacement rates has weakened its role as an incomemaintenance instrument (especially for upper income earners).

A turnaround strategy has markedly improved the finances and financial management of the UIF. The National Treasury (2008: 97-98) reported that the Fund had achieved unqualified audit reports during the past two years, and an actuarial valuation in March 2007 indicated that it would be able to meet its cash-flow requirements over the next ten years for a range of possible claims scenarios. The UIF's capital and reserves amounted to R18.5 billion at the end of March 2006.

The basic role of the UIF remains the provision of short-term benefits that combat the effects of frictional and cyclical unemployment. It was not designed to combat large-scale structural unemployment. The reality that only about one in every seven unemployed persons (600 000 out of a total of 4.2 million) receive UIF benefits is indicative of the limited scope of unemployment compensation in South Africa.

The Compensation Funds provide income benefits and medical care to workers injured on the job, funding for the rehabilitation of disabled workers, and survivor benefits to the families of victims of work-related fatalities. The main Compensation Fund is administered by the Department of Labour and covers workers in sectors 
other than mining and construction, while the Department of Health administers the Mines and Works Compensation Fund, which provides benefits to victims of working conditions-related lung diseases. ${ }^{11}$ Levies on employers finance these funds. Various efficiency-enhancing reforms of the main Compensation Fund have been implemented as part of a turnaround strategy initiated in September 2007. The combined accumulated surplus of the compensation funds at the end of March 2007 amounted to $\mathrm{R} 7.2$ billion.

State disability grants are available to people disabled in circumstances other than road and work-related accidents. The grant is paid to disabled persons between the ages of 18 and the retirement age who do not receive other state grants and who are not cared for in state institutions. Eligibility is determined by strict medical-based criteria: the disability should be permanent and sufficiently severe to prevent the affected person from entering the labour market. Hence, the purpose of the grant is to compensate disabled persons for loss of income. The same means test applies to disability grants and social old-age pensions - see Section 2(c).

\section{Old age}

South Africa has a well-established retirement fund market. Membership of an occupational fund is widely accepted as an obligatory condition of employment, and the coverage rate for formal-sector employees of about 60 percent is high by international standards. According to the National Treasury (2007a: 5), South Africa's ratio of pension fund assets to GDP of 63 percent compares favourably with those of countries such as Australia, Chile, Malaysia, Singapore and the United Kingdom.

Coverage rates, however, vary considerably across income categories. Middle- and high-income earners are well covered: the National Treasury (2008: 100-101) recently reported that almost all formal-sector employees who earn more than R120 000 per annum belong to a pension, provident or retirement fund. Favourable tax treatment contributed to this relatively high level of cover. Among lower-income earners, however, coverage is much less comprehensive: some 360000 formal employees in the R60 000 to R120 000 income category and fully 2.7 million of those earning less than R60 000 per annum are without retirement coverage. In total, only an estimated 5.9 million of the 8 million formal-sector workers (i.e. roughly one-half of the about 12.3 million employed and one-third of the 16.8 million economically active South Africans) have retirement coverage (National Treasury, 2008: 100).

Moreover, income replacement rates for pension and provident fund members often are inadequate because of limited access to cost-effective instruments combined with early withdrawals. Estimates indicate that less than half of those who reach retirement age with a funded pension receive more than 28 percent of their preretirement incomes (National Treasury, 2007a: 5). The Smith Committee (1995: 18) found that 40 percent of occupational pensions paid had a lower value than the social old-age pension.

Lower-income South Africans (including many formal-sector workers) therefore depend on social pensions in old age. The means-tested social pension is payable to persons of retirement age and older; during his Budget Speech in February 2008,

${ }^{11}$ The mining and construction sectors have separate compensation arrangements. 
the Minister of Finance announced that the retirement age for men will be lowered gradually from 65 to 60 years to bring it in line with those of women by 2010 . As was indicated earlier, the maximum amount of the pension currently is R940 per month and in April 2008 an estimated 2225354 elderly people received it. The means test for the social old-age pension is discussed in Section 2(c).

\section{2(c) Targeting and means testing}

Targeting and means testing are important aspects of the South African social security system for at least three reasons. First, their aim is to channel resources allocated to social security programmes to those in greatest need. Hence, means testing and other targeting mechanisms are key determinants of the efficiency of resource use in social security systems. Second, they link and integrate the occupational insurance and social assistance aspects of the system. Third, they have major influences on the behavioural incentives created by the system.

\section{Targeting}

Two types of errors could arise in the process of targeting social grants. Errors of exclusion occur when poor people are excluded from benefits, while errors of inclusion occur when there is a leakage of funds meant for the poor to those who are not poor. Such errors have their origins in the functioning of targeting mechanisms. There are a number of alternative mechanisms for targeting grants or other subsides to the poor:

- $\quad$ Means testing is generally used in South Africa for social grants.

- $\quad$ Categorical subsidies or transfers are also sometimes linked to indicator targeting. This is for instance the case with the free health care for pregnant woman and young children that was introduced at the time of the transition to democracy in South Africa. Though pregnant woman and young children are not all poor, the fact that these services are subsidised does mean that many poor people benefit from it, although there would be errors of exclusion and errors of inclusion involved in this.

- Geographic targeting targets certain areas because they house many of the poor. In South Africa the child support grant had an element of geographic targeting (the means test that applied until 2008 favoured rural areas and squatter areas), as does the housing subsidy (which favours urban areas).

- A fourth mechanism is self targeting. The Working-for-Water project, which pays low wages to people willing to work on certain projects, relies on this mechanism. Only the poor are usually willing to work at such low wages, with the result that it targets itself: only the poor are the beneficiaries.

Targeting can be costly in a number of senses. The costs of administering targeting can amount to as much as 3 to 8 percent of the value of the grants, for example, and tend to increase with attempts to improve the accuracy of targeting. Furthermore, targeting often carries moral hazard and other incentive costs: introducing targeting often leads to changes in the behaviour of potential beneficiaries that are undesirable from society's viewpoint. Some people, for example, may stop working to claim an unemployment grant. A third cost of targeting is stigma. In many Anglo-Saxon countries, where means testing is common, some people do not want to be seen as "being on welfare"; hence, they refuse to apply for grants to which they are entitled. 
Only poor children can participate in certain school feeding programmes in South Africa, and some poor children refuse to do so because of the associated stigma. In such cases, it may be better to consider making the grant available to everybody, despite the higher costs (i.e. committing an error of inclusion), rather than to exclude some poor children through the stigma effect (an error of exclusion). Finally, targeting also involves political economy costs. For instance, the political support for a grant targeted only at very poor people may be less than that of a grant reaching a larger group, as is the case with the South African old age pension.

Analysis based on concentration curves suggest that South Africa's social assistance grants are well targeted. The derivation of a concentration curve is similar to that of a Lorenz curve in that one first arranges the population from poorest to richest, after which the curve is plotted. In the case of the Lorenz curve, cumulative income is shown on the $\mathrm{Y}$-axis and the cumulative population share on the $\mathrm{X}$-axis. The further the Lorenz curve bends from the diagonal, the greater the extent of inequality. In the case of the concentration curve, the cumulative benefit, subsidy or grant is shown on the $\mathrm{Y}$-axis and the cumulative percentage of the population on the $\mathrm{X}$-axis. If the concentration curve lies above the Lorenz curve, such spending is at least weakly redistributive. When the concentration curve also lies above the diagonal, the spending programme is strongly redistributive or equity enhancing. In this case, the concentration curve shows targeting towards the poor, i.e. redistribution in per capita terms. Figure 5 shows a Lorenz curve and a concentration curve for social grants in 1997. Whereas the Lorenz curve lies below the diagonal in the usual fashion, the concentration curve lies well above it. Whilst it is not possible for the bottom 40 percent of the population, for instance, to earn more than 40 percent of the income, it is indeed possible for them to receive more than 40 percent of the spending on social grants. In 1997, for example, the bottom 40 percent of the population received approximately 70 percent of the spending on social grants.

Figure 6 indicates that government spending on grants is markedly better targeted at the poor than are other forms of social spending. The concentration curve for social

Figure 5

\section{Lorenz curve and concentration curve for social grants (1997)}

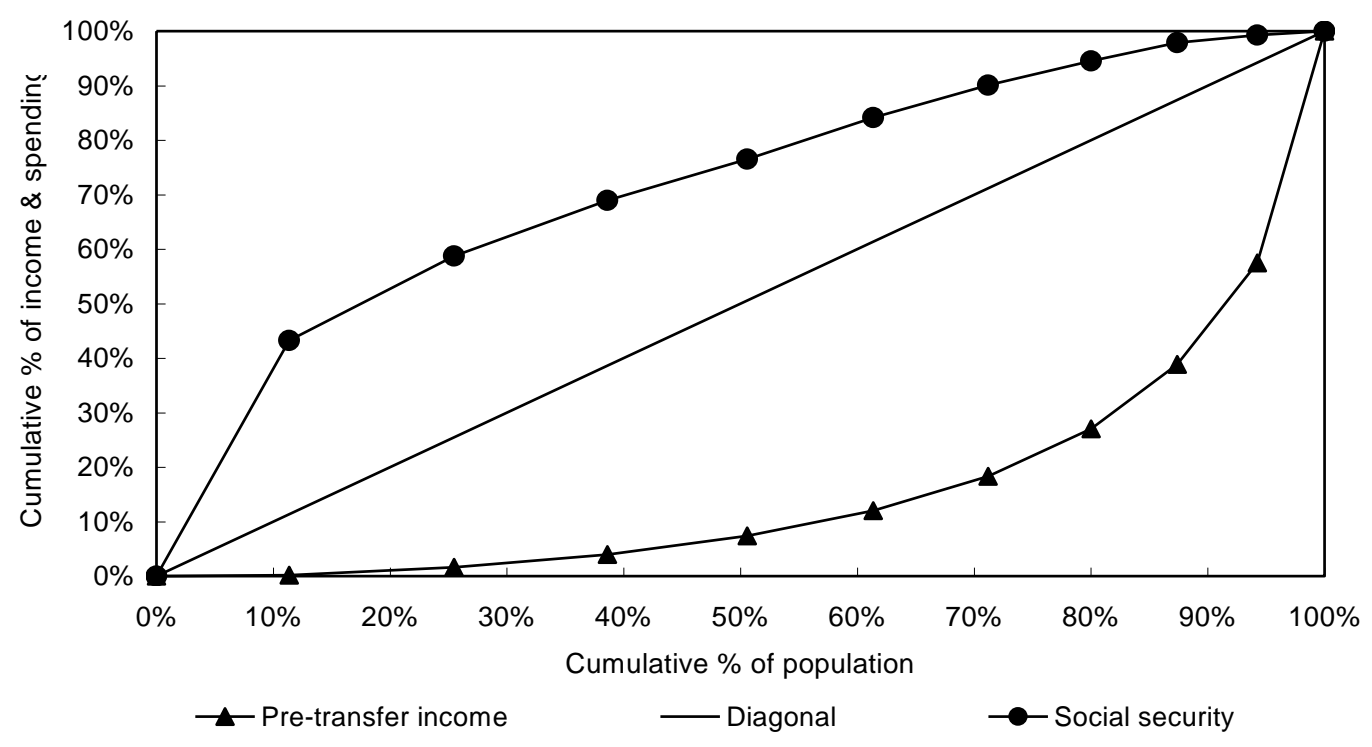


grants in 2000 lies well above those for other social programmes; hence, the degree to which the poor's actual share of spending on such grants exceeds their proportional share is greater than for other social expenditure programmes. This is confirmed by Table 4, which shows concentration indices for social spending programmes for both 1995 and 2000. A concentration index is calculated much like a Gini index, but its value is negative when the concentration curve rises above the diagonal. As can be seen in the table, the concentration indices for social grants in both 1995 and 2000 were negative, and considerably lower than those for other social expenditure items.

Figure 6

Concentration curves for social spending programmes (2000)

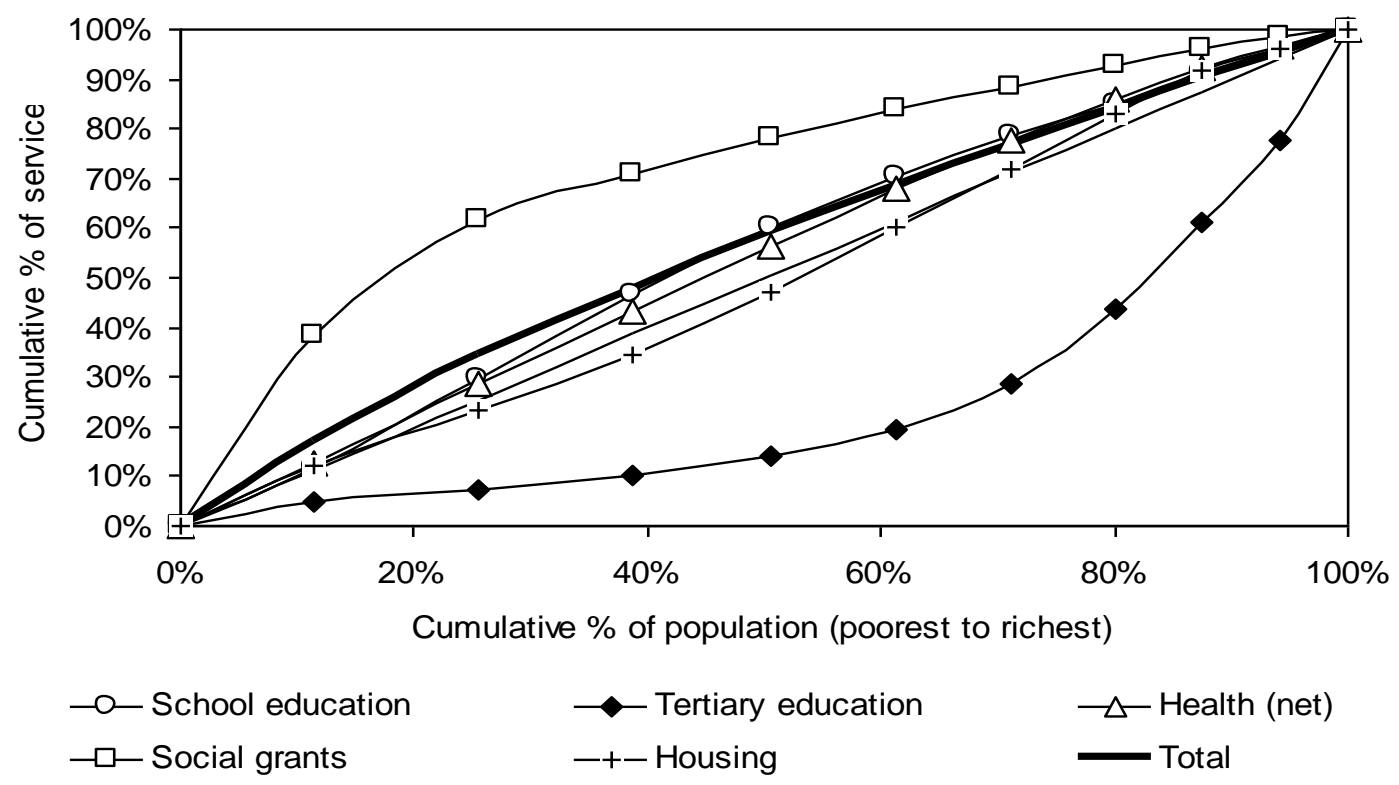

Table 4

Concentration indices for social programmes (1995 and 2000)

\begin{tabular}{lccr}
\hline Programme & \multicolumn{3}{c}{ Concentration indices } \\
& 1995 & 2000 & Change \\
\hline School education & -0.016 & -0.104 & -0.088 \\
Tertiary education & 0.484 & 0.497 & 0.013 \\
Health: hospitals & -0.014 & -0.057 & -0.043 \\
Health: clinics & -0.103 & -0.132 & -0.029 \\
Social grants & -0.434 & -0.431 & 0.003 \\
Housing & -0.018 & 0.007 & 0.025 \\
Total & -0.057 & -0.120 & -0.063 \\
\hline
\end{tabular}

The various social grants are not targeted equally well. Figure 7 shows that social old-age pensions were targeted best in 2000 , followed by disability grants. Child support grants and maintenance grants were targeted less well. The child support grant 
programme was not yet fully rolled out in 2000 , however, and therefore may not have reached poorer and especially rural areas as well as it should have. The situation may well have improved markedly since then.

Figure 7

Concentration indices for various social grants (2000)

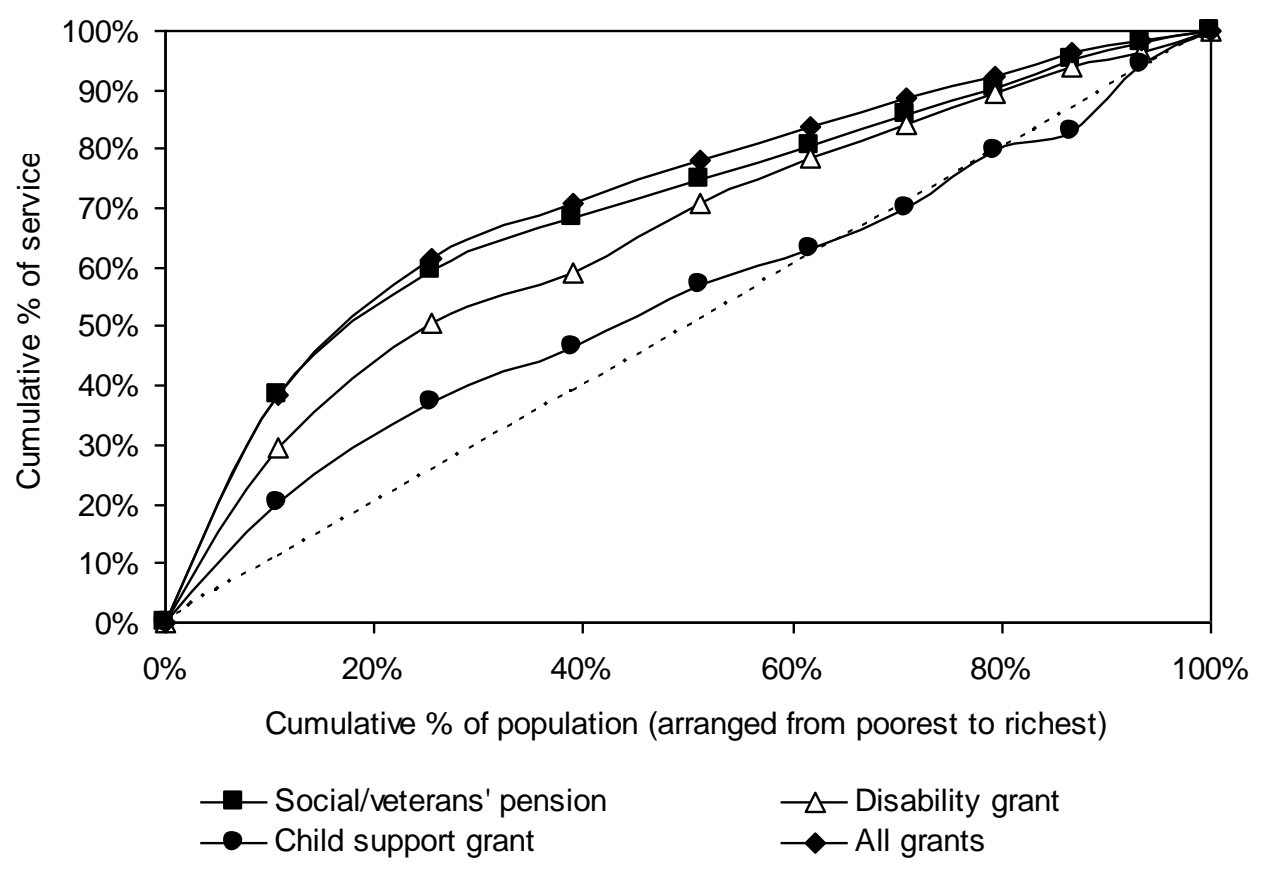

It transpires from Figure 8 that grants programmes also are more effective than other social spending programmes at reaching the rural poor. In 2000, for example, rural dwellers comprised only 42 percent of the South African population, but received fully 56 percent of the social grants disbursed.

Figure 8

Geographical distribution of social spending and the population (1997)

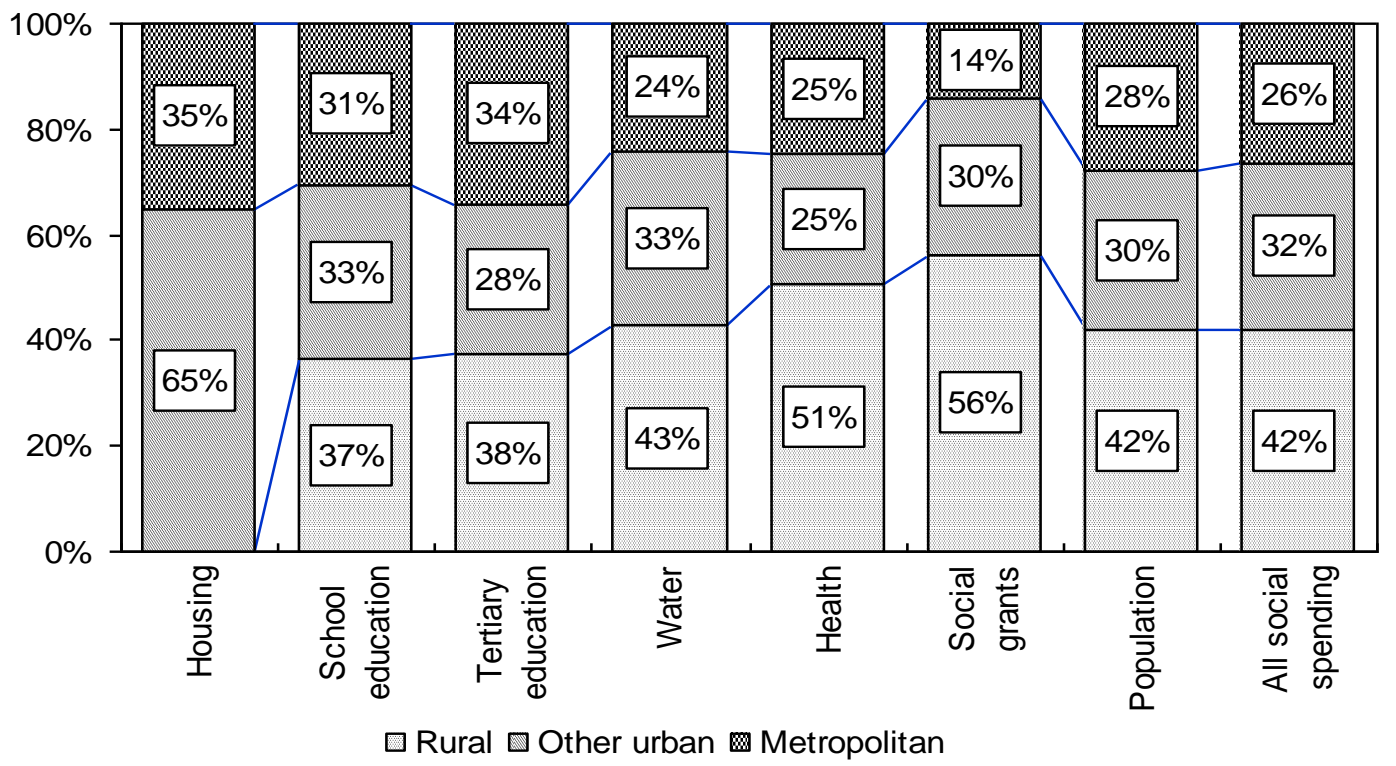


Figure 9 contains cumulative density or cumulative distribution curves for five groups. The income per capita of individuals was derived by allocating to them average income per capita of the household in which they resided. The curves show that poverty was less prevalent amongst the elderly than amongst the population as a whole: a smaller proportion of the pension-aged fell under any poverty line one could draw than was the case for the overall population. Put differently, there was so-called stochastic poverty dominance - irrespective of the poverty line chosen, the pensionaged exhibited less poverty than the population as a whole. This was undoubtedly the result of the wide reach of the old-age pension, which made it an important source of income even in relatively poor rural areas.

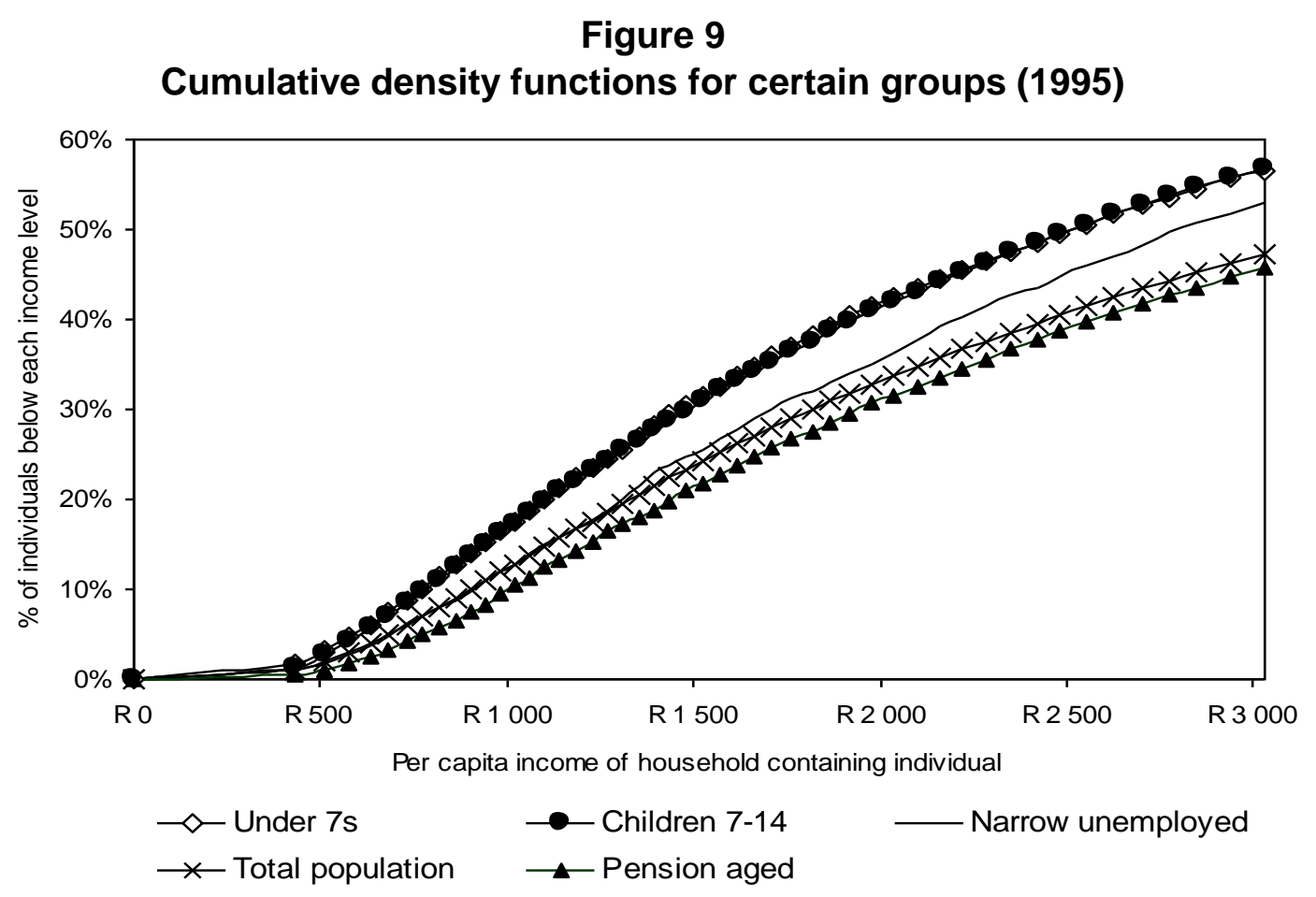

In contrast, in 1995, when this figure was derived, the children in the age groups 0 to 6 and 7 to 14 experienced greater poverty than the population as a whole, and even than the narrowly unemployed. However, it is impossible to distinguish between children 0 to 7 and children 7 to 14 in terms of this graph, so it is clear that the nature and extent of poverty in these two groups did not really differ. Therefore, it made sense that the child support grant was later extended from the younger age group to the older group of children as well, which considerably reduced poverty. It is noticeable also that the narrowly unemployed, although poorer than the population as a whole, were not as badly off as children, who more often found themselves in poorer households than was the case for those narrowly unemployed. (This, however, was before the introduction of the CSG.)

Means testing is essential for ensuring that funds target the poor rather than the less poor part of the population. Means testing has always been a part of the South African social grant system (see Van der Berg, 2001), and the major social grants are linked to explicit means tests. The remainder of this subsection outlines the current means tests for the various social grants in South Africa, while Section 3 discusses their incentive effects. 
In his Budget Vote Speech delivered on 30 May 2008, Minister of Social Development Zola Skweyiya (2008) announced new social assistance regulations that included changes to the various means tests. The new means tests are as follows:

- $\quad$ Over time, failure to adjust the exclusion thresholds announced when the child support grant was introduced in April 1998 (household income levels of R800 per month for children living in formal urban dwellings and R1 100 for those living in rural areas and informal urban dwellings) prevented growing numbers of children from accessing assistance. The revised test has a significantly higher exclusion threshold and no longer differentiates between urban and rural areas. The new formula for determining the income threshold for the child support grant is $A=B * 10$, where $A$ is the income threshold and $B$ the monthly value of the grant. Following the increase in the value of the grant to R230 per month, the income threshold now amounts to R2 300 per month (previously R1 900 per month).

- The new means test for care dependency grants is similar to that for child support grants: $A=B * 10$, where $A$ is the income threshold and $B$ the monthly value of the grant. The monthly grant amounts to R940, which implies an income threshold of R9 400 per month (previously R4 000 per month).

- The means test formula for the social old-age pension is: $D=1.3 \mathrm{~A}-0.5 \mathrm{~B}$, where $D$ is the monthly pension payable, $A$ the maximum monthly pension payable, and $B$ the monthly private income of the beneficiary. Of course, this is subject to the constraint that the maximum grant cannot exceed the set maximum, which now amounts to R940 per month (R11 280 per annum). An additional provision states that the cost of administering grants smaller than R100 per month is regarded as excessive; hence, no such grants are payable. The maximum grant of R11280 per annum therefore is paid to elderly people with private incomes of R6 768 per annum or less (see Figure 10). A clawback (or effective marginal tax rate) of 50 percent operates for incomes from R6 768 to the exclusion level of income of R26 400 per annum. Yet another proviso states that no grant is paid to individuals whose assets exceed R450 000 (i.e. 40 times the maximum benefit).

- $\quad$ The same means test formula applies to the disability grant: $\mathrm{D}=1.3 \mathrm{~A}-0.5 \mathrm{~B}$, where is the monthly disability grant, $\mathrm{A}$ the maximum monthly disability grant, and $B$ the monthly private income of the beneficiary. The grant may not exceed the set maximum, which now amounts to R940 per month (R11 280 per annum). Additional provisions state that grants amounting to less than R100 per month are not payable, and that no grant is paid to individuals whose assets exceed R450 000 (i.e. 40 times the maximum benefit).

Being subject to the same means test implies that the disability grant gives rise to a poverty trap similar to that affecting the social old-age pension. Indeed, there is little incentive for a disabled person to take up work. The problem is compounded by the reality that the work offered to the disabled tends to be temporary and low-paid (Lund, 1998: 12), which makes the income differential between the wage and the disability grant rather small. 
The means test sometimes penalise lower-income workers with inadequate occupational pensions to such an extent that their retirement incomes (i.e. the sum of the occupational pension and the social pension) are only slightly higher than those of others who have contributed for much shorter periods. In this sense, the meanstested nature of the social old-age pension reduces the incentive for low-income earners to join a retirement fund.

\section{Figure 10}

The operation of the means test for the old-age pension (2008)

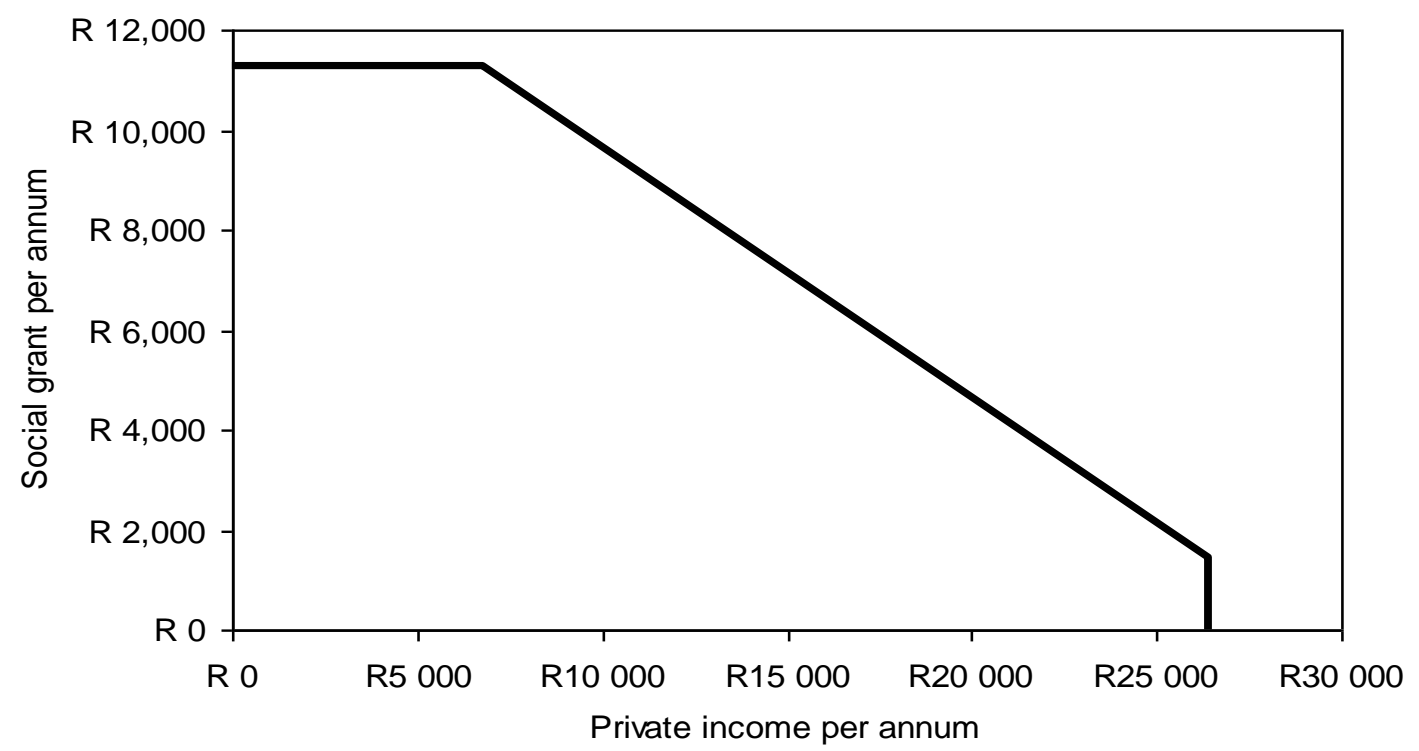

The first question one should ask when discussing means testing is whether it serves as a means of inclusion or a means of exclusion. If the means test is set at a high level, such as case with the social old age pension, it is largely used to exclude a small segment of the population with a fairly high income from benefiting. In South Africa's case, approximately 80 percent of the eligible age group receive social old age pensions. In contrast, if means testing is to be used to focus only on the bottom part of the population, i.e. to target a relatively small group of very poor people, it could be much more difficult to apply, because at such low income levels the poor cannot always be clearly distinguished from the less poor. This is linked to how incomes are usually distributed, i.e., they tend to follow a log-normal distribution, meaning that there is a lot of bunching of incomes around low income levels. It is therefore very difficult to draw a poverty line that runs through the middle of this bunching of incomes and to separate those who are very poor from those who are slightly less poor, as has been attempted with the child support grant. For this reason the means test for the child support grant is quite difficult to apply and there are probably many errors of inclusion as well as errors of exclusion, plus a large degree of discretion in application of this grant, which makes the means test problematic. However, because of the relatively small magnitude of the grant compared to the old age pension and disability grant, a more complex means test is also not desirable.

The working of the means test should be considered in the context of the income distribution. It is crucial where the centre of the log-normal distribution lies. Until recently, it was probably below the threshold value of where the sliding scale started to operate, as very few black people had retired with private retirement income. This 
is changing, however, as changes in the 1970's had brought more black people into the social insurance net, so that many of them are now entering retirement with some level of private pension. That means that more and more people are retiring with private incomes in the range where the sliding scale is supposed to be operating, making application of the means test more difficult and accurate information about people's actual private incomes essential. For this reason there is a strong case to be made to extend the social pension to include also the top 20 percent of the retired population and to take back some of this income through the tax system. This means in practice that the social old age pension then becomes a universal pension. Because South Africa is so close to that situation, and because of the increase in administration costs associated with trying to deal with a differentiated pension for different people along the sliding scale, it may be useful to again consider this. The Smith Committee, the Mouton Committee and the National Consultative Retirement Forum all considered the option of eliminating the means test for the old age pension, but all came to the conclusion that it was best to retain it, as the number of pensioners was growing more rapidly than the economy was, and consequently there would have been strong pressure on the fiscus as a result of the expansion of the number of beneficiaries. However, the growth rate of the economy has improved and consequently it may again be worth considering the abolition of the means test for old age pensioners in the present conditions.

A number of studies have shown that social pensions are major sources of income in the South African context (particularly for the rural poor) with important effects on household formation (Klasen and Woolard, 2009; Bertrand, Miller and Mullainathan, 2003; Case and Deaton 1998; Case, Fin and McLanahan, 1999; Duflo 2003). Since many adults in South Africa do not have own incomes, households often form around available sources of income. Therefore unemployed adult children or other relatives of pensioners often remain in or even join such pensioner households as a survival strategy. This has an impact on choice of residence (urban or rural location), labour market participation, and may retard the growth of the urban informal sector. On the other hand, it brings a significant source of security for the unemployed, who benefit from being attached to such pensioner households. The poorest households are those with neither social grants nor employment.

\section{2(b) The Constitutional framework}

Section 27(1)(c) of the Constitution of the Republic of South Africa (No. 108 of 1996) stipulates that everyone has the right to have access to social security, including appropriate social assistance for those unable to support themselves. As is the case with various other social rights conferred by the Bill of Rights (Chapter 2 of the Constitution), it is stated further that the state should take reasonable legislative and other measures, within its available resources, to achieve the progressive realisation of this right. Hence, the South African Constitution is transformative in nature: "... it does not simply place limits on the exercise of collective power... but requires collective power to be used to advance ideals of freedom, equality, dignity and social justice" (Brand, 2005: 1).

For the governments of middle-income countries such as South Africa, giving effect to such constitutional social rights represents a major challenge. The post-apartheid Government has managed to maintain fiscal discipline while significantly expanding the coverage and poverty-alleviating impact of the social assistance system. 
Whether or not enough has been done to satisfy the constitutional imperative obviously is difficult to establish, however, and some human-rights advocates have argued that a more aggressive approach was required in view of the extent and persistence of poverty in South Africa (e.g. South African Human Rights Commission, 2006: 65-66).

The Constitutional Court has approached its role as the custodian of the constitutional socio-economic rights with circumspection, and has been reluctant to impose additional policy burdens on the executive (Davis, 2006: 304). On the whole, the Court has rejected the notion that the South African Government has a minimum core obligation to the people of the country as far as the realisation of socioeconomic rights is concerned; instead, its jurisprudence has reflected a reasonableness approach that emphasises "... rationality (non-arbitrariness); a demand for reasons backed up by evidence (justification); and proportionality between means and ends, between advantages and disadvantages" (Pillay, 2007: 4). ${ }^{12}$

The Constitutional Court nonetheless has not shied away from making judgments with significant budgetary implications. ${ }^{13}$ This was affirmed in a case heard on 13 and 30 May 2003 and decided on 4 March 2004 - Khosa and others versus Minister of Social Development 2004 (6) SA 505 (CC) - that dealt with sections of the Social Assistance Act (No 59 of 1992) which disqualified persons who were not South African citizens from receiving social assistance grants. The Court ruled that the citizenship requirement infringed the Constitutional right to equality of citizens of other countries living in South Africa as permanent residents, and that permanent residents were bearers of the right to social security that the Constitution vested in "everyone". Accordingly, the Social Assistance Act (Act 13 of 2004) expanded the eligibility for social assistance to include South African citizens and persons resident in the Republic.

\section{2(c) Social security administration}

The social security funds (the Compensation Fund, the Road Accident Fund and the Unemployment Insurance Fund) are Section 3A public entities, that is, extensions of government departments with mandates to fulfil specific economic or social responsibilities of government. Legislation governs the management, operations and reporting obligations of these funds. The Commissioners of the Compensation Fund and the Unemployment Insurance Fund report to the Minister of Labour, while the Chief Executive of the Road Accident Fund reports to the Minister of Transport.

Schedule 4 of the Constitution of the Republic of South Africa (No. 108 of 1996) lists welfare services as a functional area of concurrent national and provincial legislative competence. The White Paper for Social Welfare (Department of Welfare, 1997) proposed the following division of labour:

\footnotetext{
${ }^{12}$ The notion of a minimum core obligation was introduced by the United Nations' Committee on Economic, Social and Cultural Rights in its General Comment 3 (released in 1990).

${ }^{13}$ In the judgment in the case Minister of Health versus Treatment Action Campaign 2002 (5) SA 721 (CC), the Court distinguished between scrutiny of budgetary issues directed at "rearranging budgets" and scrutiny of budgetary issues with "budgetary implications", indicating that the first type is not its domain.
} 
National government is responsible for developing generic norms and standards for providing services, and for ensuring that uniformity in the performance of particular functions is maintained. Provinces are responsible, concurrently with the national department, for planning, development and providing services. However, where mutual cooperation between national and provincial departments is essential, powers are allocated concurrently.

In practice, this boiled down to a separation between the administrative and delivery aspects of the social assistance system: overall responsibility for policy and administration vested in the national Department of Social Development, while provincial departments managed the payment of social grants. In 2004, administration and the disbursement of social grants were unified when the South African Social Security Agency Act (Act 9 of 2004) established the South African Social Security Agency (SASSA). Its mandate is regulated by the Social Assistance Act (Act 13 of 2004). Following the transfer of the social assistance administration and payment service functions to SASSA in 2006 and 2007, the national Department of Social Development now focuses on the development and reviewing of social policy and monitoring of service delivery. The delivery of social welfare services is now the main activity of the provincial departments of social development.

SASSA was created to promote efficiency and improve service delivery in the social assistance system, mainly by improving coordination and raising administrative standards. It is envisaged, for example, that consolidation and standardisation of contracts with grant payment contractors (which account for 76 per cent of total payments to beneficiaries) would reduce the administrative costs of providing social grants (National Treasury, 2008: 330). SASSA also has made a concerted effort to combat fraud by cleaning up its records of the recipients. Among other initiatives, regular audits of the social pension system (SOCPEN) were introduced in conjunction with the Department of Social Development and the Special Investigations Unit. In 2008 it was reported that these audits have yielded the following results (National Treasury, 2008: 329):

- $\quad 21588$ government employees who were on the system illegally were removed and subjected to disciplinary actions.

- $\quad$ Apart from these government employees, the removal from the system of an additional 143485 people had been recommended as well.

- The annual value of the 165073 grants that have been suspended totalled R424 million.

- 6693 people had been arrested and taken to court, where a conviction rate of more than 80 percent was achieved.

- Acknowledgements of debts amounting R77.5 million had been signed, and R16.6 million had been recovered from recipients not entitled to grants.

- The payment of grants to 123610 beneficiaries had been cancelled because of non-collection or direct requests from beneficiaries.

The Social Assistance Act (Act 13 of 2004) established an independent Inspectorate for Social Assistance, funded by money appropriated by Parliament, to combat abuse of the social assistance system and to audit compliance by SASSA with regulatory and policy measures and instruments. 


\section{2(d) The budgeting framework}

Prior to the establishment of SASSA, funds allocated for the payment of social grants formed part of the provincial equitable share, which is a direct charge on the National Revenue Fund. Accordingly, the formula for the division of the provincial equitable share allocation among the provinces contained a welfare component - based on the estimated numbers of people entitled to grants weighted by means of a poverty index derived from the Income and Expenditure Survey - with a weight of 18. In terms of the present budget framework, social assistance transfers are shown in the Comprehensive Social Security Framework programme on the budget of the Department of Social Development, from where it is transferred to SASSA for disbursement. The provincial equitable share formula was amended accordingly by scrapping the welfare component and re-weighting the other components.

Two broader sets of reforms during the recent past have also affected the budgetary framework governing the social assistance system. In November 1997 South Africa entered a new phase of fiscal planning with the publication of the first Medium Term Budget Policy Statement. Subsequent budgets have been presented in the context of a medium-term policy frameworks consisting of three-year rolling expenditure and revenue projections for the national and provincial governments compiled against the backdrop of economic and fiscal goals and prospects for the economy. The promulgation of the Public Finance Management Act (PFMA) of 1999 was a major step to increase the transparency and accountability of fiscal policymaking in South Africa. The Act emphasises regular financial reporting, sound internal expenditure controls, independent audit and supervision of control systems, improved accounting standards and training of financial managers, and greater emphasis on outputs and performance monitoring. Furthermore, it compels the South African fiscal authorities to disclose their longer-term objectives and views about future trends in fiscal policy annually, along the lines of the existing medium-term budgeting framework.

\section{INTERNATIONAL PERSPECTIVES ON SOCIAL GRANTS}

\section{3(a) OECD countries}

Social insurance programmes absorb about 85 percent of total social security expenditure in OECD countries and social assistance schemes the remaining 15 percent (World Bank, 2006: 1). ${ }^{14}$ The overall coverage of social assistance schemes remains low despite significant increases in the number of recipients of grants since 1980: in 1999, only 3 percent of the working-age populations of continental European countries and 9 percent of that of the United Kingdom received targeted social assistance benefits (De Neubourg et al, 2007: 17-18). ${ }^{15}$ Social assistance schemes therefore

\footnotetext{
14 These averages mask considerable variation. Anglo-Saxon countries generally devote larger chunks of their social security outlays to social assistance schemes and correspondingly smaller portions to social insurance programmes than the countries of continental Europe (International Labour Organisation, 2000: 181; World Bank, 2006: 2).

${ }^{15}$ The International Labour Organisation (2000: 180) ascribed this increase in the number of socialassistance beneficiaries to growing unemployment, changes in employment patterns that have prevented growing numbers of workers from accumulating adequate entitlements for full income protection, the proliferation of single-parent families, and reductions in the levels of social insurance benefits.
} 
play a residual role in the social security systems of most industrialised countries and their impact on poverty and inequality tends to be marginal. Such schemes nonetheless are very effective at, as De Neubourg et al (2007: 13) put it, "weaving the safety net tightly" for those needy people who receive inadequate or no benefits from contributory programmes and other forms of social protection (cf. also International Labour Organisation, 2000: 179). In a number of these countries, social assistance programmes function as income guarantee schemes that complement contributory schemes by providing tax-financed minimum incomes on a means-tested basis. Other common types of social transfers in OECD countries include cash and in-kind housing benefits, universal or means-tested family benefits, cash benefits for lone parents, employment-conditional benefits for able-bodied individuals, and childcare benefits (World Bank, 2006: 3).

In recent decades, a number of trends in OECD countries have caused concern about the long-term financial viability of social protection systems, including rising long-term unemployment, globalisation-induced pressure on tax bases and tax rates, population ageing and changes in family structures such as growing numbers of oneparent families (World Bank, 2006: 5). Along with mounting unwillingness among taxpayers to pay for social protection caused in part by perceptions of growing welfare dependence among the recipients of grants (cf. De Neubourg et al, 2007: 30), these trends have stimulated widespread reform of social assistance and other components of social security systems. The remainder of this subsection discusses the nature of these reforms in broad terms and provides a more detailed review of one of its most prominent examples, namely workfare programmes.

Debates about the reform of social assistance schemes in OECD countries have revolved around links between the nature of such schemes, work incentives, and social exclusion. ${ }^{16}$ To discourage dependence on social grants, many OECD countries have reduced the amounts and duration of benefits and tightened requirements that beneficiaries should seek work actively (World Bank, 2006: 7). Such reforms often have been accompanied by the following measures to encourage working and social inclusion: terminating the practice of cancelling benefits when recipients obtain part-time work, changing the delivery of benefits from the household to individuals so that individuals do not jeopardise the household's access to benefits when they find jobs, providing benefits conditional on finding employment (e.g. cash bonuses, wage supplements and tax credits), and offering more assistance to job seekers (labourmarket information, training programmes, etc) (World Bank, 2006: 7). This has been described as a shift from protective to productive modes of providing social assistance (and social protection more generally) (Hudson and Kühner, 2009). ${ }^{17}$

The United States pioneered modern welfare reforms aimed at integrating recipients of social benefits into the formal labour market. The approach, which has become

\footnotetext{
${ }^{16}$ Social exclusion is defined as "... a multi-dimensional socio-economic conception of deprivation" that often involves "... the development of an 'underclass' mentality, with little emphasis on the personal responsibility to find work" (World Bank, 2006: 7).

${ }^{17}$ There is some debate about the actual extent of this shift in focus. Hudson and Kühner (2009), for example, compared the welfare states of 23 OECD countries in 1994, 1998 and 2003 and found that a shift towards the productive model of social protection occurred in some but by no means all of them.
} 
known as workfare ${ }^{18}$, can be traced back to experimental programmes introduced by the Reagan Administration in 1981, but reached maturity under the Clinton Administration with the implementation of the Personal Responsibility and Work Opportunity Act (PRWORA) of 1996 and other welfare reforms. Ochel (2005: 78) defined workfare as "programmes or schemes that require people to work in return for social assistance benefits" and stressed three aspects of this definition:

- $\quad$ Participation in workfare programmes is compulsory for unemployed people deemed physically and mentally able to work and non-compliance with programme requirements could jeopardise recipients' benefits.

- $\quad$ The primary focus of workfare programmes is work; training and other mechanisms to achieve reintegration into the labour market are of secondary importance.

- Workfare programmes are linked with policies tied to the lowest tier of public income support.

The major elements of US workfare programmes are as follows (cf. Blank, 2004: 48). First, PRWORA abolished the matching-grant Aid to Families with Dependent Children (AFDC) programme and replaced it with Temporary Assistance to Needy Families (TANF), provided to states as a block grant. The introduction of TANF allowed the states much more discretion over programme design than AFDC, and the block-grant basis raised the importance of careful design by transferring the full financial risk of cycles in assistance needs to states. The PRWORA legislation also made access to federal funds conditional on states placing larger numbers of their active welfare recipients in jobs, limited TANF-funded assistance to 60 months over the full lifetimes of individuals, and limited access to income assistance programmes among targeted groups (e.g. immigrants and certain categories of disabled persons). The states responded to the PRWORA legislation by:

- $\quad$ markedly expanding their welfare-to-work programmes

- $\quad$ reducing the earnings disregard (i.e. the rate at which cash benefits decrease as earnings increase) to encourage working

- $\quad$ enforcing benefit losses on assistance recipients who did not participate in work programmes

- $\quad$ enforcing the Federal 60-month limit on eligibility for TANF-funded assistance and, in some cases, setting and implementing even tighter limits

Other policy changes strengthened state-level efforts to get welfare recipients in jobs. These included the expansion of in-kind assistance to needy families by means of child-care subsidies, food stamps and Medicaid services, as well minimum wage increases and expanded refundable tax credits under the Earned Income Tax Credit (EITC) system (Blank, 2004: 9-12).

In a careful review of the empirical evidence, Blank (2004: 14-18) highlighted three major results of this gamut of changes:

- Welfare caseloads dropped by 42 percent from 1994 to 2001, and did not rebound significantly during the $2000-2001$ recession.

\footnotetext{
${ }^{18}$ According to Kildal (2001: 3), the term "workfare" is derived from "work-for-your-welfare" or "welfare-for-work".
} 
- Employment increased sharply during the late-1990s, especially among lessskilled single mothers. Data from 2002 showed that the majority of the women who had left welfare in the 1990s remained employed, although a significant minority were jobless.

- The incomes of single mothers (the group affected most heavily by the changes) rose during the second half of the 1990s, despite the fact that many of them lost cash benefits as a result of the introduction of workfare.

These developments suggest that workfare programmes have succeeded in their primary aims of reducing welfare caseloads and moving welfare recipients into jobs. Blank (2004: 37-40), however, added that it is particularly difficult to separate the effects of such programmes from concurrent labour-market developments such as the rapid growth in job opportunities and earnings in the US during the second half of the 1990s; furthermore, it is too soon to ascertain some of the longer-term effects of the welfare reforms on the livelihoods and social choices of needy families.

Welfare reforms with workfare elements were also implemented in the United Kingdom by the Labour Government of Tony Blair, as well as in the Scandinavian countries. The UK reforms, known as the New Deal, offer assistance to four groups of welfare recipients: young unemployed persons aged 18 to 24, long-term unemployed aged 25 and above, lone parents and disabled people (cf. Kildal, 2001: 4; Ochel, 2006: 80-81). Younger unemployed persons first enter a period of intensive jobsearch (the "Gateway"), after which they have to choose among four six-month options, namely subsidised employment, full-time education and training, voluntary service, and the Environmental Task Force (Ochel, 2006: 80). This is followed by another period of intensive job search (known as the "follow-through"). Unemployed persons aged 25 and above who have received the Jobseeker's Allowance continuously for 12 to 18 months undergo a 13-week Gateway period, followed by an Intensive Activity Period that lasts another 13 weeks and provides subsidised employment or education and training opportunities (Ochel, 2006: 81). Several studies reviewed by Ochel (2006: 80-81) found that the New Deal programmes successfully promoted the employment of younger and long-term unemployed people.

The Scandinavian countries have long combined a commitment to the maintenance of full employment (pursued by means of active labour-market policies, inter alia) with the belief that generous social benefits for the unemployed are basic social rights regardless of achievements and financial means (cf. Kildal, 2001: 5-6). During the second half of the 1990s, however, the forces listed earlier led the governments of these countries to also introduce workfare-like welfare reforms, with Denmark leading the way. Prior to a series of labour-market reforms introduced from 1993 until 1998, the jobless in Denmark could indefinitely access unemployment benefits, provided that they participated in work programmes for six months during each threeyear benefit cycle (Kildal, 2001: 7-9). The first wave of reforms abolished the right to earn new benefits through participating in work programmes by limiting the period of entitlement to seven years, of which the last three years involved compulsory "activation initiatives" aimed at reintegration into the labour market. The limits subsequently were tightened and by 1998 the maximum unemployment period was four years, including three years of activation activities. In 1996, these steps were complemented by special measures for low-skilled individuals under 25 years of age, who after six months of unemployment were compelled to enter education or work training pro- 
grammes and accept sharply reduced benefits. Ochel (2006: 81) reported positive employment effects for these Danish workfare programmes, but Kildal (2001) was more circumspect and expressed concern about the implications of such programmes for norms of fairness and justice that have long underpinned the Scandinavian welfare regimes.

The available evidence therefore indicates that workfare programmes can be effective mechanisms for returning welfare recipients to work, especially in rapidly growing economies where sufficient numbers of jobs are created to absorb programme participants in the regular labour market. The importance of the availability of jobs is magnified by the reality that workfare programmes affect the low-skilled labour market by assisting unemployed people in getting regular public or private sector employment. In contrast to public works programmes, which provide governmentcreated temporary jobs, workfare therefore causes competition between social security recipients and regular workers for low skilled work in the formal labour market (e.g. sweeping streets, cleaning parks, and basic clerical tasks). In some cities in the US, such as Baltimore, regular low-skilled workers were displaced by workfare workers, who were not unionised and were paid less than the minimum wage (Samson, Rosenblum, Haarmann, Haarmann, MacQuene and Van Niekerk, 2001: 4). The perverse result was that people who were in regular paying work ended up on welfare because their jobs were taken by workfare participants. Hence, inadequate availability of jobs may well be the most serious barrier to the successful implementation of workfares programmes. Furthermore, the US experience showed that workfare programmes can be time-consuming and financially expensive: the costs to be taken into consideration are the work-related and child care expenses of recipients as well as supervisory and administrative costs (Samson et al, 2001: 12). In discussing the Scandinavian experience, Kildal (2001: 14) also warned that workfare-type programmes could easily lead to two-tiered labour markets in which poor labourers are compelled to work on "second-rate terms", lacking labour rights and sickness, vacation and unemployment benefits.

\section{3(b) Developing countries}

The colonial authorities introduced rudimentary social security systems in most African, Asian and Latin American countries. Such systems offered health care, maternity leave, disability allowances and pensions for small sections of the population - mainly civil servants and employees of large enterprises - but bypassed the numerically dominant poor (especially those living in rural areas) (Townsend, 2007: 32). After obtaining independence, a considerable number of developing countries introduced or expanded social assistance programmes to assist households not covered by social insurance schemes. Such schemes usually were afforded a relatively low priority compared to social services such as education and health care, however, and funding was restricted further by limited tax resources. To this day, the benefits provided by most developing countries have remained modest. Furthermore, in most countries coverage have remained low and restricted to the victims of particular contingencies (e.g. widows, orphans and elderly people without income and family support). International Labour Organisation data reported by Townsend (2007: 179-180, 181) suggest that approximately 90 percent of the inhabitants of South Asia and Sub-Saharan Africa and 20 to 60 percent of the populations of middle-income countries lack any form of statutory social protection. The bleak 
picture extends to the formerly socialist countries of Central and Eastern Europe. Prior to 1989, these socialist countries did not provide unemployment insurance, and devoted limited resources to social assistance schemes. Even by the turn of the century, the share of social security expenditure they devoted to social assistance and unemployment benefits remained marginal (ILO, 2000: 56).

Several developing countries apart from South Africa maintain substantial social assistance systems, including Brazil, Mexico, Botswana, Namibia and India (cf. Townsend, 2007: 32-34). Arguably the most thoroughly studied reform initiative in recent years has been the introduction of conditional cash transfers (CCTs) in several Latin American and Central American countries. The remainder of this section provides a brief review of the Latin American experience with CCTs.

Latin America's inequality and poverty problems were exacerbated by the debt crisis of 1980 and the contagion effects of the Mexican and Asian crises of 1995 and 199798, which reversed the economic recovery of the early 1990s. Amidst this turbulent economic environment within which social spending levels often came under severe pressure, Latin American countries introduced conditional cash transfer programmes (CCTs) to overcome the most common shortcomings of traditional social assistance schemes, including poor targeting of the needy, high administrative costs, fragmentation of projects and programmes, accusations of paternalism and clientelism, and an overemphasis on short-term relief of poverty with inadequate attention to longer-term poverty of a structural nature (Rawlings and Rubio, 2005: 30, 33). Britto (2005: 2-3) summarises the essence of CCTs as follows: "The operation of conditional cash transfers (CCTs) consists in the provision of money subsidies to targeted households, provided they assure school attendance of their school-aged children and, in some cases, make periodic visits to health centers and attend other healthrelated activities." Hence, CCTs combat current poverty (by providing income support that enables consumption smoothing) as well as future poverty (by encouraging human capital accumulation among the young in an attempt to break the intergenerational poverty cycle) (Rawlings and Rubio, 2005: 33). According to Britto (2005: 3), other objectives of CCTs are to overcome the failure of universal social policies to reach the poor - especially in the areas of education and health - and the failure of existing systems to provide adequate social protection during times of crisis.

CCTs were initiated by Mexico to replace the regressive and urban-biased general food subsidy scheme (Britto, 2005: 7-8), but soon spread to other countries in Latin America and the Caribbean. Introduced by President Ernesto Zedillo, the Mexican Progresa scheme provided cash and in-kind transfers to households whose children regularly attended school and whose members visited health centres regularly. The education component of Progresa targeted poor households with children in primary and secondary school, providing educational grants and support for school materials. The scheme also included supply-side benefits: teachers, for example, got bonuses for every pupil who was on the programme. The health component focused on poor households with pregnant and lactating women, children under two years of age, and malnourished children between the ages of two and five; the benefits included cash grants for food consumption, basic health services, nutrition and health education, and nutrition supplements (Rawlings and Rubio, 2005: Table 1). Furthermore, Progresa had a positive gender bias: benefits were disbursed to the female heads of participating households, and secondary-school girls received larger cash grants 
than boys, because the former faced higher risks of dropping out of school and their educational attainment brought positive externalities (Britto, 2005: 8). In 2002, Progresa was renamed Oportunidades and its scope was expanded to also include income generation for poor households by means of preferential access to microcredit, housing improvements, and adult education (Rawlings and Rubio, 2005: 32).

President Fernando Henrique Cardoso introduced the Bolsa Escola conditional cash transfer programme in Brazil in 2001. This programme granted monthly cash transfers to poor households with children aged six to fifteen enrolled in grades one to eight, provided that they maintain school attendance rates of 85 percent or higher (Britto, 2005: 10-11). Bolsa Escola benefits were also disbursed to female heads of households. The benefits provided by the national governments were significantly lower than those of Progresa, but richer states and municipalities were allowed to raise the transfers or expand coverage. The details of the targeting of beneficiaries were also left to municipalities (Britto, 2005: 11). In 2003, Bolsa Escola was unified with other federal CCTs, creating a programme known as Bolsa Família. Apart from better coordination with other social spending initiatives, Bolsa Família added healthrelated conditionalities to Bolsa Escola's education-related ones and markedly extended the coverage and size of transfers. It soon became Brazil's largest CCT in terms of coverage and financing (Britto, 2005: 12).

Very similar CCT schemes exist in some other Latin and Central American countries, including Colombia, Jamaica, Nicaragua and Honduras (cf. Rawlings and Rubio, 2005: 31-32). In Honduras, pupils receive education vouchers and supply-side incentives encourage schools to participate. The health and nutrition grants are targeted at newborn babies until the age of 3 years or pregnant mothers in Honduras and Jamaica. Honduras also gives health and nutrition vouchers and nutrition training for mothers, and provides health centres with incentives to participate.

CCT programmes use a variety of targeting mechanisms. Honduras uses the Height Census of first-grade school children to obtain data on the extent of malnutrition. ${ }^{19}$ In Mexico, the qualifying communities in rural areas are selected using a marginality index based on census data. Nicaragua compares the results of household-level proxy means testing to results from geographic targeting. Furthermore, in Jamaica, beneficiaries' eligibility is continuously reviewed. This happens every three years in Mexico as well. In Nicaragua the programme only lasts three years in a community and is then phased out within two years; hence, inhabitants know that it is only a temporary measure (Rawlings and Rubio, 2005: 38).

The evidence suggests that CCT programmes are effective mechanisms for alleviating poverty, and this is reflected in increases in budgets and the number of recipients. When Progresa began in Mexica it covered 300000 people compared to more than 4 million people - or 20 percent of the population - in 2002 (Rawlings and Rubio, 2005: 38). The same trend is observed in Brazil, where the coverage of Bolsa Escola reached some 5 million people in 2002 (Britto, 2005: 7). Rawlings and Rubio (2005:48) reported that CCTs have had positive effects on school enrolment among boys and girls, child health and nutrition, and consumption levels. Brazil's 2000 census showed that school attendance rates among poor children had increased by $4 \%$,

\footnotetext{
${ }^{19}$ Duflo (2003) used a similar methodology in a study to determine the nutritional status of South African children staying with an old age pension recipient.
} 
while that of Argentina rose by $9 \%$ for beneficiaries between the ages of six and 17 between 2005 and early 2007 . This does not necessarily imply that child labour had declined, however, because school attendance can be combined with work (Britto, 2005: 13). Britto (2005: 25) also pointed out that the effectiveness of CCTs is influenced markedly by the environment within which they are implemented. In the Latin American context, for example, sustainable poverty reduction is likely to require appropriate macroeconomic policy, various redistributive policies and initiatives to enable the poor to accumulate more assets, in addition to CCT programmes.

\section{EFFECTS OF SOCIAL SECURITY IN SOUTH AFRICA}

\section{4(a) The theory of the household}

The household has been considered as both a consumption and production structure (Becker, 1991; Edmonds et al, 2004). The unitary model of household behaviour assumes that members of the household behave altruistically and that the household's utility is maximised when pooled resources are allocated equitably among its members (Becker, 1991). A household considers its production function and as a collective bargaining unit decides on whether it needs additional income, and if it would be able to afford to support the member who is looking for work (Black, 2004: 416). A household would take the decision to insure itself against risk by diversifying its sources of income and for consumption smoothing over time and for this it may require of a member of the household to migrate in search of work. This will highly depend on the search costs and additional income that may be gained from the job search (Black, 2004). However, the definition of households has implications for the social grants' impact on poverty and their behavioural impact on labour supply.

The definition of household membership has significant bearings on research outcome when assessing how social security affects households. This is more so in South Africa's case where the conventional nuclear family is less common and there are many cases of three to four generations living in the same household (Dinkelman, 2004). The question of who is included as part of the household is important. As noted by Posel et al (2006), specific criteria are used to determine household membership when household surveys are conducted. A key issue in this regard is whether membership is determined by physical presence in a household or by resource sharing (in which case some physically absent individuals could be counted as household members). The strict residency rule stipulates that a person must be a resident of the household for most of the year, to be counted as part of that household. The advantage of this rule is that it avoids double counting of individuals during censuses as well as reporting errors, because respondents are more likely to remember details about people they see almost daily (Posel et al, 2006: 838). The broad rule accommodates members who are at home for at least fifteen days in a year. This rule is a more realistic account of South Africa's complex household structures, because it accommodates the fact that households are dynamic and driven by economic factors like employment. It also takes account of the widespread occurrence of migrant labour in South Africa, which had its roots in apartheid-era settlement patterns and has been perpetuated by spatial differences in the availability of job opportunities (Posel et al 2006; Lund, 2006). To show the complexities of definition, Edmonds et al (2004) use the term 'households' to refer to coresident individuals and "family" as the relatives of the household. It is unclear 
whether 'household' would exclude member of household working away from home. Posel et al (2006), who consider the household to include migrant labourers, found a positive impact of the pension on labour force participation, while Bertrand et al (2003) and Dinkelman (2004), who treated the household as exogenous and looked at labour responses to social grants, found different results.

Dinkelman (2004) observed that households have four main roles in South Africa. First, they are private safety nets for individuals without employment. Despite the fact that these individuals do not work, they are able to share in the resources of the household by attaching themselves to households that have pension recipients (Klasen and Woolard, 2009). Second, households are the productive units proposed by Becker (1991), in terms of which households influence members' decisions to search for work or not. This could have adverse or positive effects. In the case of women, social grants have freed up women to look for work due to the availability of household helpers and by offering income support (Dinkelman, 2004). Third, the household is a privileged source of information that furnishes a job searcher with information not available to other searchers because he or she is linked to the job market via household members. Such networks would be an advantage during times of high unemployment when education has less impact on who gets hired. Fourth, the culture of the household has a bearing on whether an individual will decide to look for work. This concept is difficult to measure because there may be other factors affecting a person's attitude towards employment which may not come from the household. Understanding household dynamics around social grants can inform policy about how best to deal with unintended consequences of the grants as well as how to use the grants system to target poor households.

\section{4(b) Social security and poverty}

Recent research has confirmed that the various social grants are well targeted at the poor and that they have a significant mitigating impact on poverty (cf. Van der Berg, $\mathrm{Yu}$ and Louw, 2008). Fully 76 percent of government spending on social grants accrues to the roughly 50 percent of individuals who constitute the poorest two quintiles of households; moreover, grants raise the income share of the poorest 40 percent of households from 4.7 percent of pre-transfer income to 7.8 percent of post transfer income.

Figure 11 gives a rough indication of the effect of social grants on the extent of poverty in 2005 (see Armstrong, Lekezwa and Siebrits, 2008: 21-22). It compares the actual incidence of poverty among households and individuals at the time of Statistics South Africa's Income and Expenditure Survey 2005 to the incidence that would have obtained if all respondents had reported zero income from social grants. The actual and hypothetical poverty rates for households were 33.2 percent and 43.9 percent, respectively. Hence, if nothing else was different, the incidence of poverty among households would have been about one-third higher in 2005 had the various types of social grants not existed. Similarly, social grants reduced the incidence of poverty among individuals from a hypothetical 55.4 percent to 47.1 percent (i.e. by 15 percent). These numbers are indicative only - they rest on the very strong assumption that the availability or otherwise of social grants has no impact whatsoever on the behaviour of households in terms of labour supply, household formation patterns, etc - but nonetheless suggest that social grants markedly reduce poverty by augmenting the incomes of poor households. 
Figure 11

Poverty rates for households and individuals (2005)

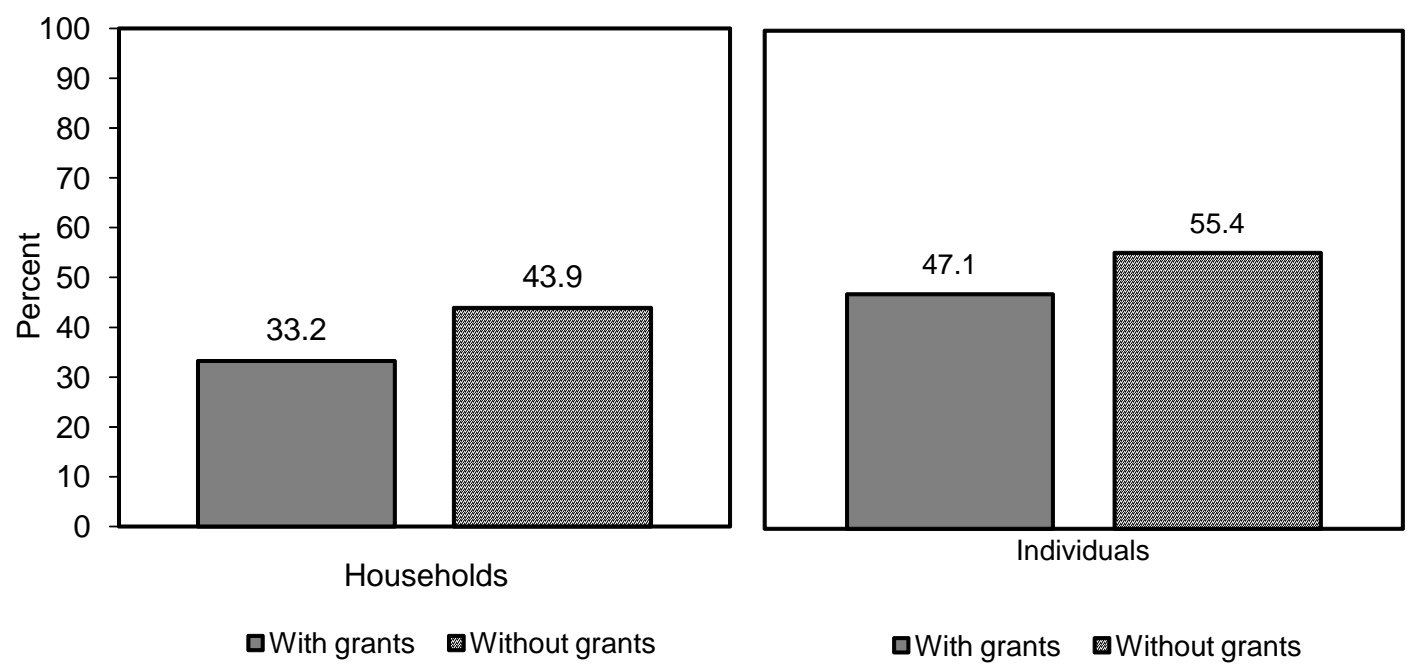

Source: Calculated from data in Statistics South Africa (2008a)

Other evidence also suggests that the recent expansion of the South African social assistance system has markedly reduced the incidence of poverty. Figure 12, which depicts poverty headcount rates based on data from AMPS (the All Media and Products Survey), shows that poverty decreased by 7 percentage points from 2001 until 2006. Moreover, the portion of children whose parents reported that they had gone hungry in the previous year declined from 31 percent in 2002 to 17 percent in 2008.

Figure 12

Poverty headcount rates based on AMPS data (1994-2006)

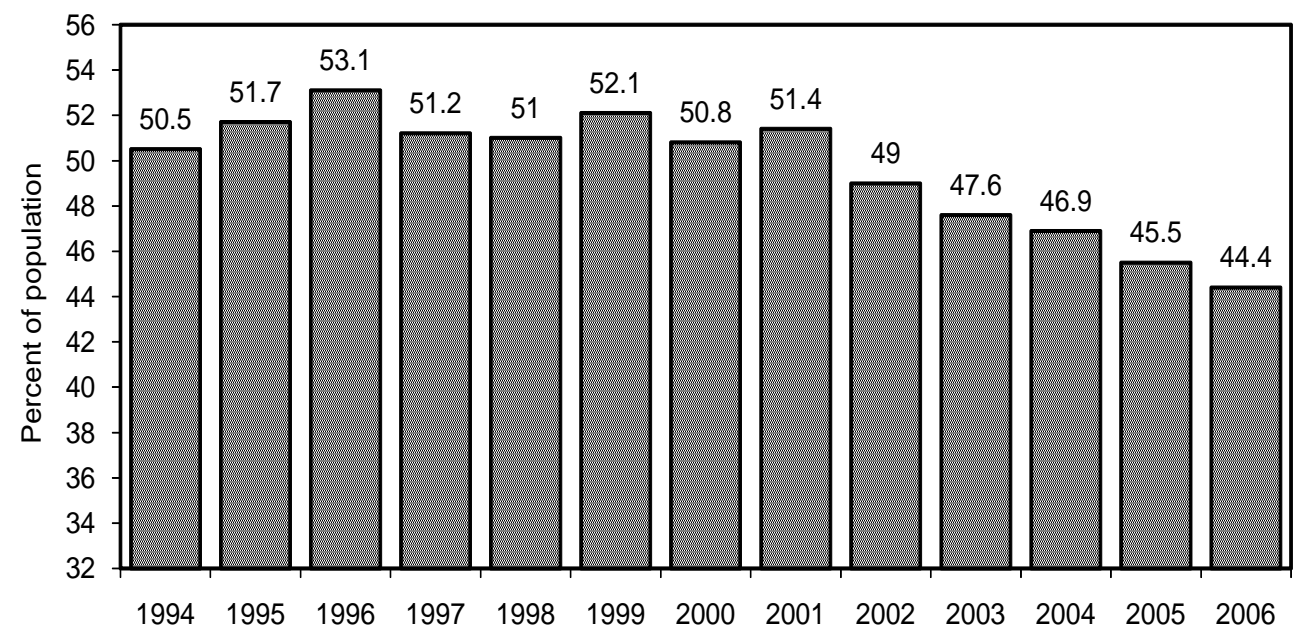

Source: Van der Berg, Louw and Du Toit (2007)

Note: Poverty line: R3 000 per capita per annum in 2000 Rand values

Social grants are important sources of income for poor households, especially in rural areas. They contribute up to $50 \%$ of income in households headed by the elderly and prevent many such households from falling into poverty (Leibbrandt et al, 2004: 13). The social grants are well targeted in South Africa because they reach most of the poor. The various grants cover children, the aged, the physically and mentally disabled and those dependent on specialised care. The old age pension is received by more than $80 \%$ of the aged and mostly black women (Case and Deaton, 
1998; Van der Berg 1999; Lund, 2006). The old age pension and the child support grant programmes are effective in transferring money to predominantly poor families, especially households with children (Case and Deaton, 1998). Social assistance to the poor in the form of grants is used like normal income would be used by the family to buy clothing, food and education (CASE, 2000: 43). It has sharply reduced the incidence of poverty (Van der Berg, Louw and Yu, 2008).

The gender of the recipient is important in the case of the old age pension: literature shows that women allocate the expenditure of the grant more efficiently than men (Duflo, 2003; Lund, 2006). Lund (2006) showed that there are improvements in the health status and nutrition of the family when the recipient is a woman. Duflo (2003) compared the weight-for-height ratios of children living in households with male pension recipients with those of households with female recipients. (The weight-forheight ratio is a good indicator of nutrition as it responds quickly to the change in environment - see Duflo, 2003: 3.) Her results were that the weight-for-height ratios of girls increased while that of boys did not change significantly in households with female pensioners. In households with male pensioners, improvements in the health status of children (boys and girls) were not observed.

The objectives of the child support grant (CSG) are to support households in meeting the cost of raising children, redistribute income, influence birth rates and relieve child poverty (Triegaardt, 2005: 252). The CSG was the result of the Lund Committee of 1996, and the principal aim was to follow the child's development irrespective of economic status. Despite administrative challenges within government, research has found that the grant has been effective in reaching children in poor households (CASE, 2000: 43). Triegaardt (2005) also noted that the CGS has been an important source of income for poor households. The unintended effect of this may have been that households have been reproducing to attain CSGs in order to avoid poverty. Receipt of child support grants has been found to be positively related to earlier school enrolment. Lund (2006) found this to be extraordinary given that some of the parents did not have a formal education and that such household tend to be poor. Despite the contribution that it makes to poverty-stricken households, the grant is not reaching all impoverished children. A reason could be that some households do not have the resources to obtain and furnish proof of material need.

South Africa lacks social security assistance for unemployed individuals who have not worked before. The Unemployment Insurance Fund (UIF) is contributory and benefits are not long lasting. Hence, the old age pension has been found to be the main source of support for unemployed individuals in the rural areas (Case and Deaton, 1998). Unemployment persists because individuals attach themselves to households that have at least one pension recipient. Klasen and Woolard (2009) took the labour market as given, and evaluated how household formation responds to unemployment. They found that the unemployed have a low propensity to set up their own households and live with pensioners to get access to resources. The adverse effect of this coping mechanism is that when resources are stretched too far some households are plunged into poverty due to the pressure on resources (Klasen and Woolard, 2009: 32-34). People are crowded into households; it is common that there is up to three generations living in the same household. Because there is no social policy that directly assists these individuals, their attachment to poor households adversely affects all individuals living in that household. 
The incentive effects of other grants, such as the foster care grant and the disability grant, are also worth noting (see also sections 4(c) and 4(d) below). Families may foster children above the CSG age of eligibility because they themselves are poor and need the additional income. The foster care grant is three times the CSG and lasts longer; therefore people have an incentive to foster children to receive this grant. A positive effect of the foster care grant is that it enables poor households to release their children to go and live with other families where they would be better cared for (Vorster et al, 2000). Social workers have observed that the grants are used as measures of poverty alleviation rather than being primarily to protect a child, and household members do not direct the spending of income towards the child (Naicker, 2005).

\section{4(c) Social security and the labour market}

A household may decide to insure itself against risk by diversifying its sources of income by sending out members of the household to look for work away from home. Bertrand et al (2003: 30) found that the social pension reduces willingness to participate in the labour force. They found a large drop in labour force participation among prime-aged males living in pensioner households, especially where the pensioners are women.

\section{The old age pension and the labour market}

Klasen and Woolard (2005) found results indicating that unemployment persists because individuals who should be actively looking for work move into households that receive pensions. The pension acts as a safety net for people who are unemployed; however, the downside is that this coping strategy negatively influences job search prospects because the households supporting them are often located far from labour market opportunities (Klasen and Woolard, 2009). They also observed that these individuals put a strain on the resources of pensioner households, pulling everyone into poverty. Although agreeing with Bertrand et al (2003) that the social grants end up supporting people whom it was not intended to support, Klasen and Woolard (2009) linked this phenomenon to the poor employment prospects of those without economic support: high search costs often prevent unemployed individuals who lack such support from obtaining work away from home.

There is a different view from Posel et al (2003), who investigated how social pensions influence household labour supply in the context of migrant labour. Posel et al (2003: 837) showed that the inclusion of migrant labourers as household members changes outcomes; in fact, they argued that pensions affect labour supply positively. They found that social grants facilitate the ability of household members to look for employment away from home. These results were more prominent among women, who left home to look for work (albeit often temporary work) away from the rural areas. Pension income frees up female labour as it contributes towards child care and also gives women financial support to migrate to places where employment opportunities exist (Lund, 2006). This is profoundly different from the results obtained by Bertrand et al (2003), who only surveyed resident household members and did not take into account the fluidity of many South African households.

The reservation wage of individuals who are not employed and who live in households with grant recipients may be higher. Kingdon and Knight (2000: 2) 
warned that higher household incomes which result in intra-household transfers to unemployed members may lower individuals' search efforts as income effects allow them more leisure - the so-called taste for unemployment hypothesis. Bertrand et al (2003) and Dinkelman (2004) found empirical support for this hypothesis. By contrast, Klasen and Woolard (2009) found little evidence of disincentive effects. Furthermore, Posel et al (2003) found no convincing evidence that prime-aged males do not actively seek employment. Black (2004: 419) argued that it is not rational to look for employment if the probability of finding it is too low compared to the effort and the costs involved in the search. For Lund (2006) these findings that suppose that prime-aged males were the main beneficiaries of pensions did not make economic sense in the current South African environment "of high unemployment and high search for jobs so desperate that it seems less credible that these men would voluntarily leave the job market" (Lund, 2006: 172).

Conclusions on the effects of social grants on the supply of labour therefore depend markedly on how the household is modelled. When it is exogenous to the model, the effects is negative; however, if migrant labourers are included as illustrated by Posel et al (2003), social pensions enable women to look for work, where they would previously have been bound by the absence of financial support and the obligation to care for children in the household. There is no conclusive evidence on the deterrent effect of pension income on labour-market participation among prime-aged males.

\section{Effects of the disability grant on the labour market}

The impact of HIV/Aids on prime-aged individuals means that households often forgo the incomes of the affected members. Disability grants (DGs) are available to those who are mentally and physically unable to effectively partake in labour-market activity, including HIV/Aids-infected individuals. Provinces undertake the assessment of eligibility differently, but the two most common methods are case-based assessment by panels consisting of social workers, nurses, social services officers and community members (Nattrass, 2006a), and examination of applicants for eligibility by district medical practitioners. In the Western Cape, only individuals who have CD4 cell counts below 200 or who are in clinical stage 4 of AIDS qualify for disability grants (Nattrass, 2006a:7). Such grants are conditional: individuals who are restored back to health no longer qualify for assistance. This provision, however, gives rise to a potential policy conflict between social welfare and the health policy of providing anti-retroviral treatment.

The Government has been providing Highly Active Anti-retroviral Treatment (HAART) to improve the health status of HIV/AIDS-infected individuals. HAART is said to be a highly effective treatment that has improved the health status of many infected persons to the extent that they have again become able to take up formal employment. Given the high unemployment rate in South Africa, some DG recipients may be induced to discontinue HAART, thus compromising their health in order to remain eligible for grants (Nattrass, 2006a). One of the dangers of discontinuation of treatment is the possible emergence of a multi-drug resistant strand of the virus which could spread throughout the population (Nattrass, 2006b). There is some evidence of alarming attitudes towards the DG: some regard it as a lifeline (and would rather contract HIV than remain poor), while others harbour the perception that people without jobs are entitled to apply for disability grants (CASE, 2005:92). 
Furthermore, there was an observed increase in the uptake of the DG between 1995 and 2005. This could in part have been because individuals engaged in risky behaviour to get grants or because of the spread of HIV-related illnesses such as tuberculosis (Department of Social Development, 2007). Vorster et al (2004) also noticed that growing numbers of women and younger individuals are receiving disability grants.

\section{The Child Support Grant (CSG) and the labour force}

There are low levels of employment among the primary care-givers (most of whom are women) of children receiving child support grants. Their employment rate is $18 \%$ compared to the national employment rate among employed women of $33 \%$ (Department of Social Development, 2007). Many of the care-givers with jobs are either poorly paid or temporarily employed. Evidence suggesting that the CSG is a deterrent to obtaining employment is yet to come to light.

\section{4(d) Other incentive effects of the social security system}

\section{The Child Support Grant}

There is evidence of an increase in teenage pregnancy between 1995 and 2005: fertility increased amongst girls in their late teens or early twenties (Department of Social Development, 2006). The possibility exists that young mothers may use the grant to gain financial independence from the household. Mothers receive the grant on behalf of the children, despite the fact that they may not effectively function as the primary caregivers. However, there is counterevidence that should also be considered. Only 5.3\% of CSG mothers are young mothers in the group 15-19 and they account for only $18 \%$ of all mothers receiving grants in the 2001 census. This implies an underrepresentation, suggesting that the existence of the grant is insufficient motivation to fall pregnant (Department of Social Development, 2006). The increase in the uptake of the grant is said to have been mostly because of growing awareness of its availability. That mothers who are not primary caregivers receive the grant is indicative of the complex structure of many African households.

\section{The foster care grant}

The possibility exists that foster parents could use foster care grant money for purposes other than assisting foster children. Due to the overload on the system, which especially affects social workers and child courts that dealt with foster cases, social workers opt to register families for the FCG if they do not qualify for the CSG "just to get them off their back" (Vorster et al, 2000: 130). Clearly, there are issues of capacity involved, with courts in poorer provinces reported to be overcrowded by claims and social workers swamped with large caseloads (Nattrass, 2006a).The increase in the uptake of the FCG noted in section $3 \mathrm{~b}$ also is related to the reality that many children are being orphaned by HIV/AIDS-related deaths.

\section{The means tests for the old-age pension and child support grant}

The means test for social pensions has a number of incentive effects: 
- $\quad$ on retirement age, as few people apart from high income earners find it worthwhile to remain in the labour force beyond the inception age for the old age pension;

- $\quad$ on own provision for retirement (e.g. private pensions), as many people have little incentive to provide for themselves if the net result will only be that they receive less from the state;

- $\quad$ on preservation of pensions when people leave their jobs and on their choice between whether they should belong to a pension or to a provident fund;

- $\quad$ on asset creation, as certain assets are less visible and therefore less likely to exclude people from benefiting from the old age pension; and

- $\quad$ on household formation, as mentioned above

Although the means test for disability grants operates in exactly the same way as that for social pensions, the major practical difficulties relate to the application of the medical criteria for eligibility. This means test would have to be retained even if the old-age pension becomes universal.

We mentioned earlier that the initial means test for child support grants was based on a two-step procedure:

- $\quad$ First, the full rural and squatter population as well as all other people with an income below R800 per month were selected;

- $\quad$ Of this group, those with monthly incomes above R1 100 were excluded.

This effectively meant that people in rural and squatter areas received the grant if their incomes were below R1 100, whilst urban dwellers received it if their incomes were below R800 per month. Hence, there was a bias towards the rural and squatter population. This bias, however, was eliminated when the means test was changed in 2008. The availability of child support grants nonetheless may still influence where and with whom children reside. Prior to the introduction of the grants, many children were left with grandmothers or relations in rural areas while their mothers searched for jobs in urban areas. The wider availability of grants in the urban areas has enabled more mothers to keep their children with them; this may have stimulated the migration of children to the urban areas. Whether such migration improves or worsens the welfare of children is not clear a priori. Children may well be better off with their mothers compared to living with grandmother or relations in rural areas, but would be left worse off if the mothers do not have the time to give children the care they need.

\section{THE MAGNITUDE AND IMPACT OF GRANTS: SOME QUANTITATIVE DIMENSIONS}

\section{5(a) The Child Support Grant}

Figure 13 confirms that the child support grant is the most rapidly growing grant type. As mentioned earlier, this grant was introduced after the political transition and has been expanded dramatically in scale and as a proportion of total spending on social grants. This has occurred largely because of the very rapid expansion of the child support grant, even at a time when the value and numbers of recipients of other grants have increased as well (see Tables 5 and 6). 
Figure 13

Percentage contribution of spending on each type of social grant to total spending on social grants

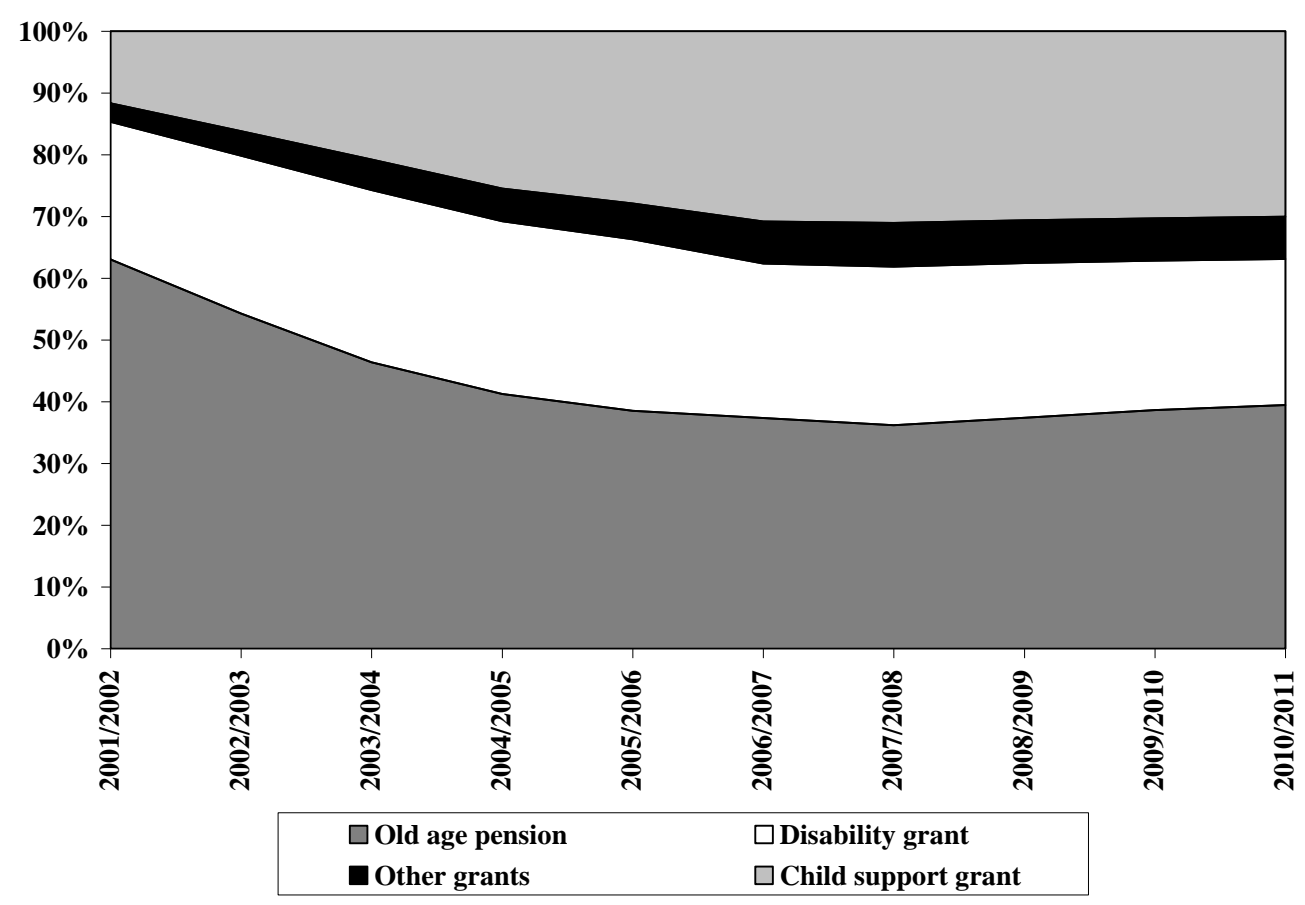

Source: National Treasury website

Table 5 shows the monthly nominal values of the various grants and how this changed over time, with the CSG at R230 from October 2008 much smaller than most other grants, notably foster care grants. Table 7 and Figure 15 show the real trends in grant values, from which it is apparent that the CSG has not consistently kept up with inflation.

\section{Table 5}

Monthly amount of each type of grant (Rand)

\begin{tabular}{|l|c|c|c|c|c|c|c|}
\hline & $\begin{array}{c}\text { Old-age } \\
\text { pension }\end{array}$ & $\begin{array}{c}\text { Disability } \\
\text { grant }\end{array}$ & $\begin{array}{c}\text { War vete- } \\
\text { rans' grant }\end{array}$ & $\begin{array}{c}\text { Foster } \\
\text { care grant }\end{array}$ & $\begin{array}{c}\text { Care de- } \\
\text { pendency } \\
\text { grant }\end{array}$ & $\begin{array}{c}\text { Child } \\
\text { support } \\
\text { grant }\end{array}$ & $\begin{array}{c}\text { Grant in } \\
\text { aid }\end{array}$ \\
\hline April 1999 & 520 & 520 & 538 & 374 & 520 & 100 & 94 \\
April 2000 & 540 & 540 & 558 & 390 & 540 & 100 & 100 \\
April 2001 & 570 & 570 & 588 & 410 & 570 & 110 & 110 \\
April 2002 & 640 & 640 & 658 & 460 & 640 & 140 & 130 \\
April 2003 & 700 & 700 & 718 & 500 & 700 & 160 & 150 \\
April 2004 & 740 & 740 & 740 & 560 & 740 & 170 & 170 \\
April 2005 & 780 & 780 & 780 & 590 & 780 & 180 & 180 \\
April 2006 & 820 & 820 & 838 & 590 & 820 & 190 & 180 \\
April 2007 & 870 & 870 & 890 & 620 & 870 & 200 & 200 \\
April 2008 & 940 & 940 & 960 & 650 & 940 & 210 & 210 \\
\hline
\end{tabular}

Source: Department of Social Development 
As Table 6 shows, growth in the numbers of recipients was quite significant for all grants since the late 1990s, but the dominant trend has been the strong growth of CSG numbers from its inception. It now constitutes almost 8.2 million grants delivered monthly, out of a total of about 12.5 million grants. Figure 14 focuses on the CSG only to show its very rapid growth.

Table 6

Number of beneficiaries of each type of grant

\begin{tabular}{|l|r|r|r|r|r|r|r|}
\hline $\begin{array}{l}\text { Fiscal year } \\
\text { (April 1 } \\
\text { March 30) }\end{array}$ & $\begin{array}{c}\text { Old-age } \\
\text { pension }\end{array}$ & $\begin{array}{c}\text { Disability } \\
\text { grant }\end{array}$ & $\begin{array}{r}\text { War vete- } \\
\text { rans' grant }\end{array}$ & $\begin{array}{c}\text { Foster } \\
\text { care grant }\end{array}$ & $\begin{array}{c}\text { Care de- } \\
\text { pendency } \\
\text { grant }\end{array}$ & $\begin{array}{c}\text { Child } \\
\text { support } \\
\text { grant }\end{array}$ & $\begin{array}{c}\text { Grant in } \\
\text { aid }\end{array}$ \\
\hline $1998 / 1999$ & 1812695 & 633778 & 9197 & 71901 & 16835 & 34471 & 8496 \\
$1999 / 2000$ & 1860710 & 612614 & 7553 & 79937 & 24438 & 352617 & 8748 \\
$2000 / 2001$ & 1877538 & 627481 & 6175 & 85910 & 28897 & 974724 & 9489 \\
$2001 / 2002$ & 1903042 & 694232 & 5266 & 95216 & 34978 & 1907774 & 10332 \\
$2002 / 2003$ & 2009419 & 953965 & 4594 & 138763 & 58140 & 2630826 & 12787 \\
$2003 / 2004$ & 2060421 & 1270964 & 3961 & 200340 & 77934 & 4309772 & 18170 \\
$2004 / 2005$ & 2093440 & 1307551 & 3343 & 252106 & 88889 & 5663647 & 23131 \\
$2005 / 2006$ & 2144117 & 1319536 & 2832 & 312614 & 94263 & 7075266 & $\mathrm{n} / \mathrm{a}$ \\
$2006 / 2007$ & 2195018 & 1422808 & 2340 & 400503 & 98631 & 7863841 & 31918 \\
$2007 / 2008$ & 2225354 & 1409434 & 1931 & 446994 & 102153 & 8189914 & 37343 \\
\hline
\end{tabular}

Source: Department of Social Development

The age-eligibility rules for the CSG have been changed in gradual steps. When it was introduced, care-givers who met the means test criteria could receive the grant until the child turned 7. This was expanded to children under 9 years in 2003, to children under 11 years in 2004, to children under 14 in 2005, and it will be further extended to children under 15 in 2009 (see Tables 7 and 8). According to the data from the GHS surveys, the coverage of individual children in the age-eligible group increased from $27 \%$ in 2002 , to $46 \%$ in 2006 , while for households with age-eligible children, coverage increased from almost 20 to $51 \%$ in the same period (Table 8). Higher coverage with an unchanged means test in nominal terms (implying that in real terms the means test became increasingly strict over the period concerned) implies that the expansion was largely the result of increased roll-out of the grant to a growing proportion of those qualifying for it.

Figure 16 shows that the GHS sample figures deviate somewhat from official figures on CSG recipients. The ratio of the reported grant recipients to the officially reported number of grants extended ranged $85 \%$ to $101 \%$ over the five years covered by the GHS, which is encouragingly close to the official figures to at least use the GHS to analyse coverage patterns. It is not clear why the deviations between the two data sources occur. With rising coverage, it may be that there is a lag before some respondents (particularly if they are not the caregiver of the child) may become aware of grant receipt. Figure 17 shows rising coverage overall as well as in each of the age groups shown. Initially when a new age group is included, there is low coverage, but this rises to around $50 \%$ of eligible households, given the current means test. The more lenient means test recently announced probably implies that 
these numbers would increase greatly. For this reason, this section of the report focuses on the CSG.

Figure 14

Number of beneficiaries of the child support grant

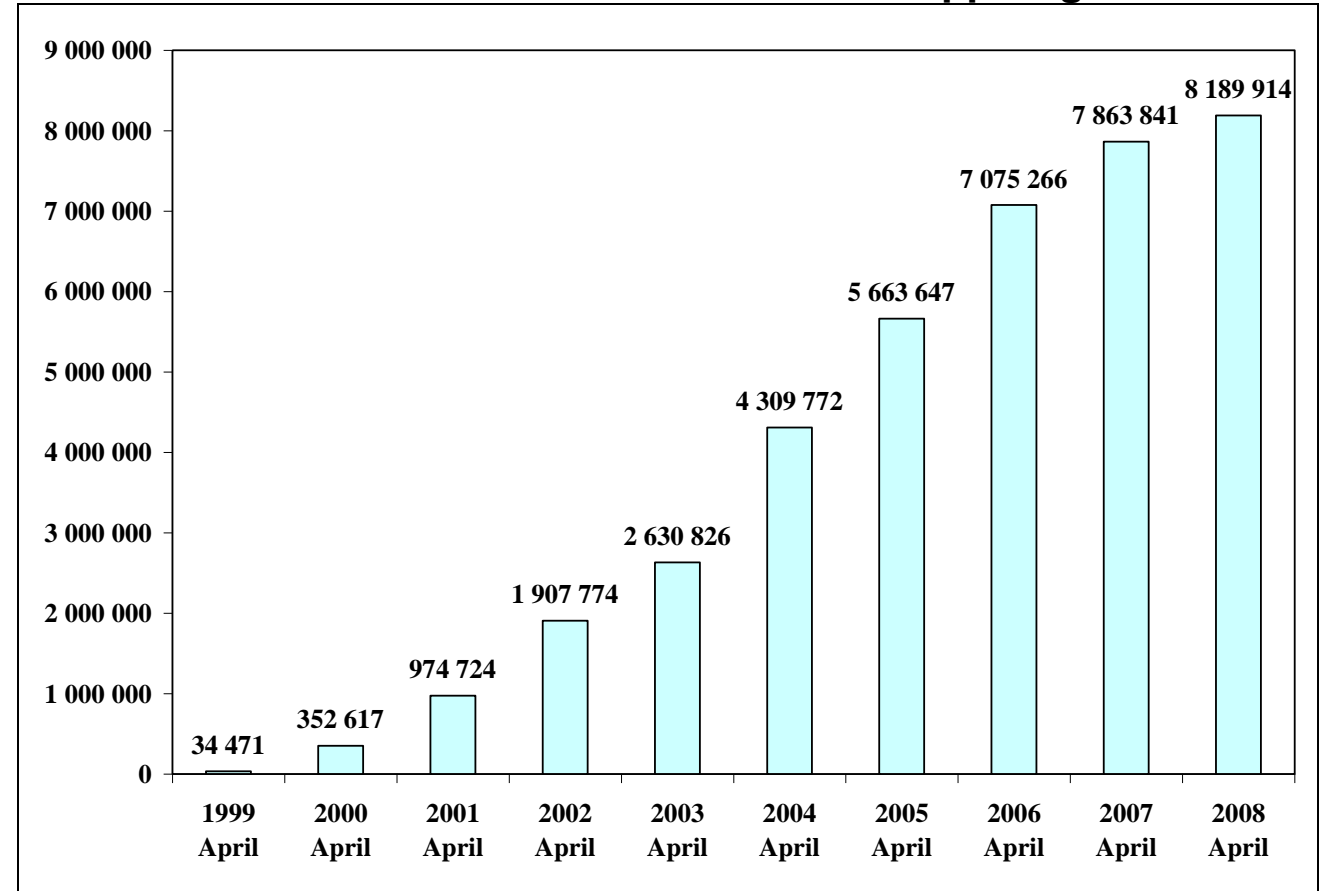

Source: Department of Social Development

Figure 15

Percentage change in the rand value of the child support grant in $\mathbf{2 0 0 0}$ prices versus the inflation rate

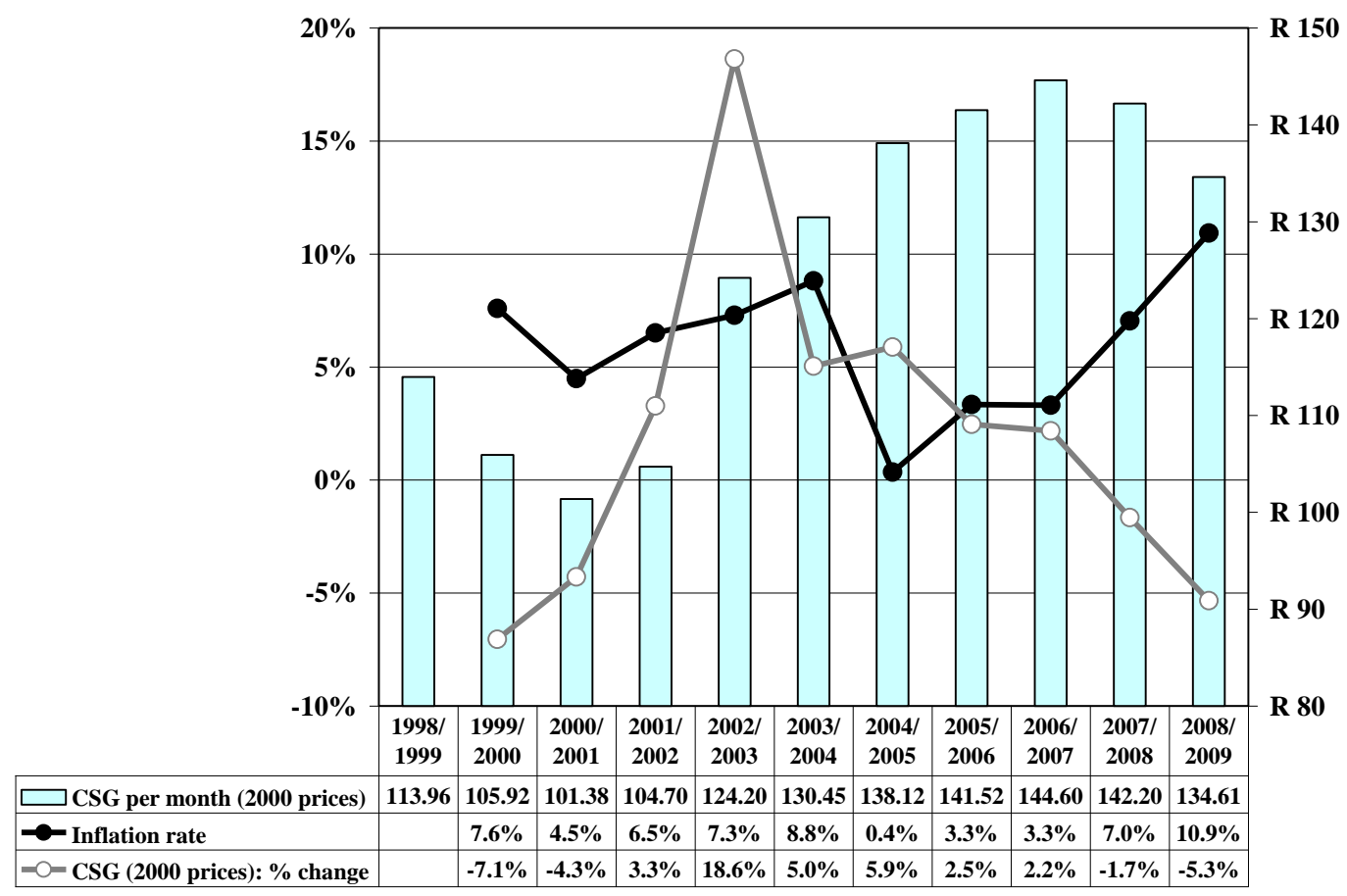


Table 7

The child support grant in South Africa

\section{Who can apply?}

$\circ \quad$ The primary care giver of the child or children concerned. The child and care giver must be South African Citizens or permanent residents.

$\circ \quad$ The child and the care giver should be resident in South Africa at the time of application.

- A child or children under the age of 14 (Note: $0-13$ years is the eligible age since 2003 April).

$\circ \quad$ The care giver and spouse must meet the requirements of the means test.

\section{Means test ${ }^{\ddagger}$}

A means test is the test used to measure the financial status of the applicant. In order to receive a grant, the applicant's financial income should be below a certain level. Until the means test was made less strict in 2008, the applicant could pass the means test if he/she lived:

o in a rural area and earned less than $\mathrm{R} 1,100$ per month or $\mathrm{R} 13,200$ per year

- in an urban area in an informal settlement and earned less than $\mathrm{R} 1,100$ per month or R13,200 per year

o in an urban area in a house or flat and earned less than R800 a month or $\mathrm{R} 9,600$ a year.

\section{Eligible age and the grant amount}

\begin{tabular}{|c|c|c|c|}
\hline Year & Eligible age & $\begin{array}{c}\text { Amount per } \\
\text { month (Nominal } \\
\text { values) }\end{array}$ & $\begin{array}{c}\text { Amount per } \\
\text { month }(2000 \\
\text { prices) }\end{array}$ \\
\hline 1998 April & $0-6$ years & R100 & R113.96 \\
\hline 1999 April & $0-6$ years & $\mathrm{R} 100$ & R105.92 \\
\hline 2000 April & $0-6$ years & $\mathrm{R} 100$ & $\mathrm{R} 101.38$ \\
\hline 2001 April & $0-6$ years & $\mathrm{R} 110$ & $\mathrm{R} 104.70$ \\
\hline 2002 April & $0-6$ years & $\mathrm{R} 140$ & R124.20 \\
\hline 2003 April & $0-8$ years & $\mathrm{R} 160$ & $\mathrm{R} 130.45$ \\
\hline 2004 April & $0-10$ years & $\mathrm{R} 170$ & R138.12 \\
\hline 2005 April & $0-13$ years & $\mathrm{R} 180$ & $\mathrm{R} 141.52$ \\
\hline 2006 April & $0-13$ years & $\mathrm{R} 190$ & R144.60 \\
\hline 2007 April & $0-13$ years & $\mathrm{R} 200$ & R142.20 \\
\hline 2008 April & $\begin{array}{c}\text { 0-13 years } \\
\text { (14-year-olds will be } \\
\text { included from 1/1/2009) }\end{array}$ & $\begin{array}{c}\mathrm{R} 210 \\
\text { (To increase to } \\
\text { R220 in } 2008 \\
\text { October) }\end{array}$ & $\mathrm{R} 134.61$ \\
\hline
\end{tabular}

Source: Department of Social Development

$\ddagger$ As mentioned earlier, the means test for child support grants changed during the course of 2008 . The details provided here constituted the means test when most of the data reported on in this section were collected.

\# The April CPI is used in each year to deflate the nominal values into 2000 values.

In 2001 April, only approximately 1 million people received the child support grants; this figure had increased to more than eight times that in April 2008. Moreover, the spending on child support grants as a percentage of total social grants spending increased continuously (from approximately 7 percent in 2000/2001 to about 30 percent in 2006/2007). 
Table 8

Number of individuals and households receiving child support grants

\begin{tabular}{|c|c|c|c|c|c|c|}
\hline \multirow{3}{*}{ GHS } & \multirow{3}{*}{$\begin{array}{l}\text { Eligible } \\
\text { age }\end{array}$} & \multicolumn{3}{|c|}{ Recipients of CSG } & \multirow[b]{2}{*}{ [D] } & \multirow[b]{2}{*}[A]{$/[D]$} \\
\hline & & {$[\mathrm{A}]$} & [B] & [C] & & \\
\hline & & $\begin{array}{l}\text { Of eligible } \\
\text { age }\end{array}$ & $\begin{array}{c}\text { Not of } \\
\text { eligible age }\end{array}$ & Total & $\begin{array}{l}\text { Population of } \\
\text { eligible age }\end{array}$ & $\begin{array}{l}\text { Coverage } \\
\text { rate }\end{array}$ \\
\hline \multicolumn{7}{|c|}{ INDIVIDUALS } \\
\hline 2003 & $0-8$ years & 2241760 & 321534 & 2563294 & 8299039 & $27.01 \%$ \\
\hline 2004 & $0-10$ years & 4201481 & 175526 & 4377007 & 11100241 & $37.85 \%$ \\
\hline 2005 & $0-13$ years & 5702793 & 139043 & 5841836 & 14052170 & $40.58 \%$ \\
\hline 2006 & $0-13$ years & 6459760 & 265579 & 6725339 & 14152509 & $45.64 \%$ \\
\hline \multicolumn{7}{|c|}{ HOUSEHOLDS } \\
\hline GHS & $\begin{array}{l}\text { Eligible } \\
\text { age }\end{array}$ & $\begin{array}{c}\text { Number of } \\
\text { households } \\
\text { containing at } \\
\text { least } 1 \text { child } \\
\text { in eligible } \\
\text { age }\end{array}$ & $\begin{array}{c}\text { Number of } \\
\text { households } \\
\text { containing } \\
\text { no children } \\
\text { in eligible } \\
\text { age }\end{array}$ & Total & $\begin{array}{l}\text { Number of } \\
\text { households } \\
\text { containing at } \\
\text { least } 1 \text { child in } \\
\text { eligible age }\end{array}$ & Coverage rate \\
\hline 2002 & $0-6$ years & 845577 & 79725 & 925302 & 4329616 & $19.53 \%$ \\
\hline 2003 & $0-8$ years & 1830602 & 42599 & 1873201 & 5141072 & $35.61 \%$ \\
\hline 2004 & $0-10$ years & 2776295 & 29621 & 2805916 & 6054697 & $45.85 \%$ \\
\hline 2005 & $0-13$ years & 3289555 & 20455 & 3310010 & 6701973 & $49.08 \%$ \\
\hline 2006 & $0-13$ years & 3504585 & 35843 & 3540428 & 6884332 & $50.91 \%$ \\
\hline
\end{tabular}

Source: Statistics South Africa General household survey (various issues)

Figure 16

The number of child support grant recipients of eligible age (a comparison of figures in the General household surveys and official figures released by Department of Social Development)

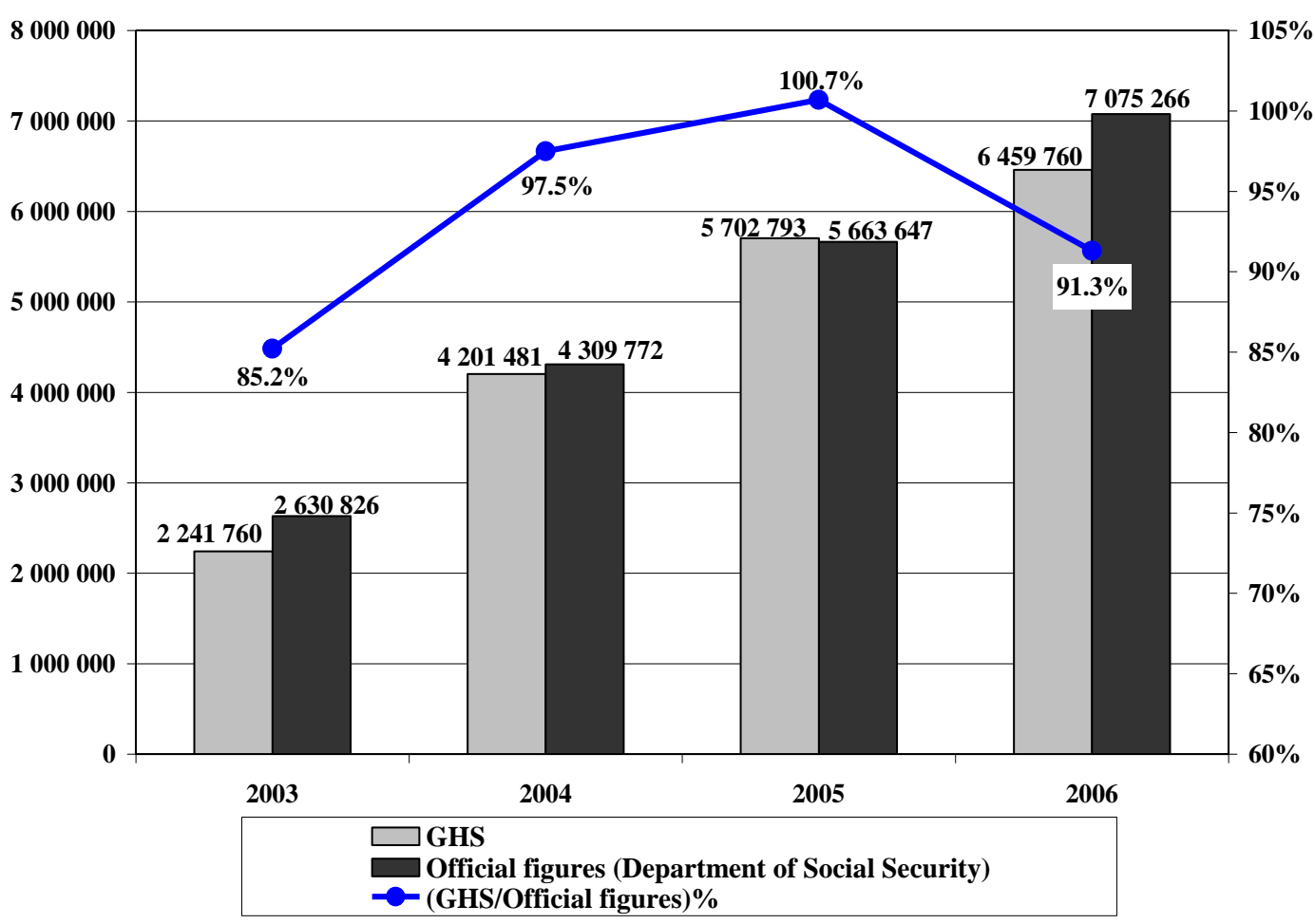


Figure 17

Child support grant coverage rates for different eligible age groups

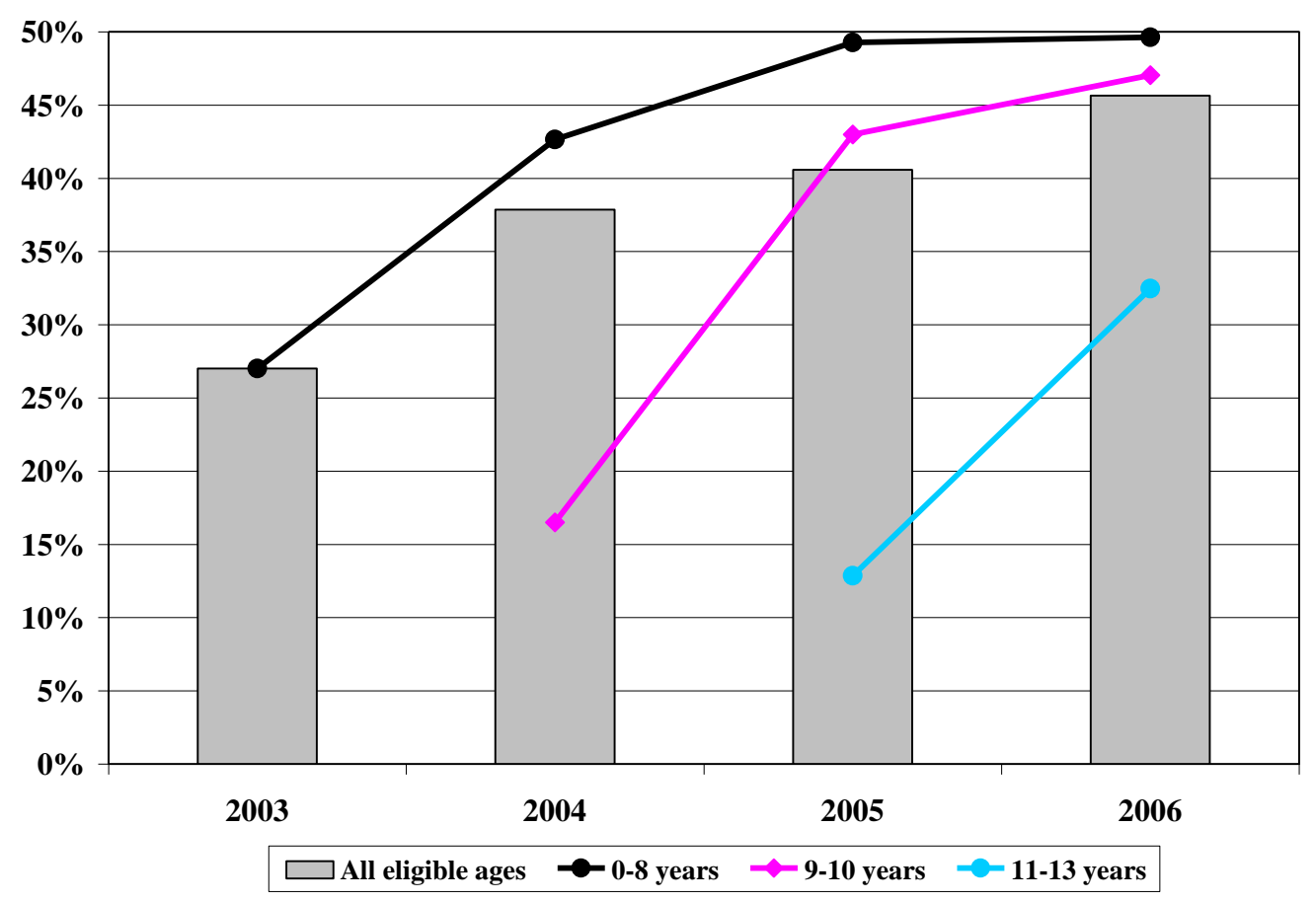

\section{5(b) Demographic characteristics}

Table 9 shows the demographic characteristics of the recipients and non-recipients of child support grants at eligible ages, and the results could be summarized as follows:

- Province: Nearly $60 \%$ of the recipients of CSG come from Eastern Cape, KwaZulu-Natal and Limpopo. For Kwazulu-Natal this high proportion reflects its population size, but for both Eastern Cape and Limpopo coverage is far higher than the national average, due to the larger number of poor children found in these two provinces. Note that the Eastern Cape's share of grants rose from $15 \%$ to $21 \%$ from 2002 to 2006 , while that for Limpopo declined somewhat.

- Area type: More than $60 \%$ of the CSG recipients reside in rural areas, though fewer than half of age-eligible children are rural.

- Gender: There is almost an even split between male and female CSG recipients, indicating that the gender of the recipient child is not an issue that affects coverage.

- Race: About $94 \%$ of the CSG recipients are black, a proportion that has not wavered over the years, despite broadening of coverage through the years.

- Attendance at educational institution at the time of the survey: In 2003, nearly two-thirds of the non-recipients did not attend educational institution at the time of the survey while the remaining one-third did, but this ratio has reversed in GHS2006. This reflects the fact that the age of eligibility for the CSG has increased, thus reaching more school-age children. 
Table 9

Demographic profile of the recipients and non-recipients of child support grants of eligible age

\begin{tabular}{|c|c|c|c|c|c|c|c|c|}
\hline & \multicolumn{4}{|c|}{ Eligible age + received CSG } & \multicolumn{4}{|c|}{ Eligible age + did NOT receive CSG } \\
\hline & GHS & GHS & GHS & GHS & GHS & GHS & GHS & GHS \\
\hline & 2003 & 2004 & 2005 & 2006 & 2003 & 2004 & 2005 & 2006 \\
\hline \multicolumn{9}{|c|}{ Province } \\
\hline Western Cape & $8.1 \%$ & $6.1 \%$ & $5.4 \%$ & $5.2 \%$ & $9.8 \%$ & $10.2 \%$ & $10.9 \%$ & $11.5 \%$ \\
\hline Eastern Cape & $15.1 \%$ & $16.1 \%$ & $19.7 \%$ & $21.2 \%$ & $16.1 \%$ & $19.1 \%$ & $15.3 \%$ & $13.8 \%$ \\
\hline Northern Cape & $1.0 \%$ & $1.8 \%$ & $1.7 \%$ & $1.6 \%$ & $2.2 \%$ & $2.1 \%$ & $2.0 \%$ & $2.2 \%$ \\
\hline Free State & $6.9 \%$ & $6.7 \%$ & $7.0 \%$ & $6.6 \%$ & $4.9 \%$ & $5.4 \%$ & $5.4 \%$ & $5.7 \%$ \\
\hline KwaZulu-Natal & $17.0 \%$ & $18.4 \%$ & $20.2 \%$ & $19.7 \%$ & $22.9 \%$ & $22.2 \%$ & $22.2 \%$ & $21.5 \%$ \\
\hline North West & $9.4 \%$ & $10.2 \%$ & $8.0 \%$ & $8.2 \%$ & $8.3 \%$ & $7.3 \%$ & $8.0 \%$ & $7.4 \%$ \\
\hline Gauteng & $11.9 \%$ & $10.6 \%$ & $10.7 \%$ & $10.9 \%$ & $18.3 \%$ & $17.7 \%$ & $17.8 \%$ & $19.3 \%$ \\
\hline Mpumalanga & $10.6 \%$ & $9.2 \%$ & $8.9 \%$ & $9.2 \%$ & $6.3 \%$ & $6.0 \%$ & $6.6 \%$ & $6.4 \%$ \\
\hline \multirow[t]{2}{*}{ Limpopo } & $20.2 \%$ & $20.8 \%$ & $18.3 \%$ & $17.3 \%$ & $11.3 \%$ & $10.0 \%$ & $11.8 \%$ & $12.3 \%$ \\
\hline & $100.0 \%$ & $100.0 \%$ & $100.0 \%$ & $100.0 \%$ & $100.0 \%$ & $100.0 \%$ & $100.0 \%$ & $100.0 \%$ \\
\hline \multicolumn{9}{|c|}{ Area type } \\
\hline Urban & $38.5 \%$ & $36.4 \%$ & $\mathrm{n} / \mathrm{a}$ & $\mathrm{n} / \mathrm{a}$ & $50.9 \%$ & $52.0 \%$ & $\mathrm{n} / \mathrm{a}$ & $\mathrm{n} / \mathrm{a}$ \\
\hline \multirow[t]{2}{*}{ Rural } & $61.5 \%$ & $63.6 \%$ & $\mathrm{n} / \mathrm{a}$ & $\mathrm{n} / \mathrm{a}$ & $49.1 \%$ & $48.0 \%$ & $\mathrm{n} / \mathrm{a}$ & $\mathrm{n} / \mathrm{a}$ \\
\hline & $100.0 \%$ & $100.0 \%$ & $\mathrm{n} / \mathrm{a}$ & $\mathrm{n} / \mathrm{a}$ & $100.0 \%$ & $100.0 \%$ & $\mathrm{n} / \mathrm{a}$ & $\mathrm{n} / \mathrm{a}$ \\
\hline \multicolumn{9}{|c|}{ Gender } \\
\hline Male & $50.0 \%$ & $51.7 \%$ & $52.0 \%$ & $51.3 \%$ & $51.0 \%$ & $52.8 \%$ & $52.5 \%$ & $52.4 \%$ \\
\hline \multirow[t]{2}{*}{ Female } & $50.0 \%$ & $48.3 \%$ & $48.0 \%$ & $48.7 \%$ & $49.0 \%$ & $47.2 \%$ & $47.5 \%$ & $47.6 \%$ \\
\hline & $100.0 \%$ & $100.0 \%$ & $100.0 \%$ & $100.0 \%$ & $100.0 \%$ & $100.0 \%$ & $100.0 \%$ & $100.0 \%$ \\
\hline \multicolumn{9}{|c|}{ Race } \\
\hline Black & $94.4 \%$ & $94.1 \%$ & $94.1 \%$ & $94.4 \%$ & $78.5 \%$ & $75.9 \%$ & $77.2 \%$ & $76.0 \%$ \\
\hline Coloured & $5.3 \%$ & $5.6 \%$ & $5.2 \%$ & $4.9 \%$ & $10.2 \%$ & $10.7 \%$ & $10.6 \%$ & $11.3 \%$ \\
\hline Indian & $0.2 \%$ & $0.3 \%$ & $0.6 \%$ & $0.6 \%$ & $2.4 \%$ & $2.7 \%$ & $2.8 \%$ & $2.7 \%$ \\
\hline \multirow[t]{2}{*}{ White } & $0.2 \%$ & $0.0 \%$ & $0.1 \%$ & $0.1 \%$ & $9.0 \%$ & $10.7 \%$ & $9.4 \%$ & $10.0 \%$ \\
\hline & $100.0 \%$ & $100.0 \%$ & $100.0 \%$ & $100.0 \%$ & $100.0 \%$ & $100.0 \%$ & $100.0 \%$ & $100.0 \%$ \\
\hline \multicolumn{9}{|c|}{ Attendance at educational institution at the time of the survey } \\
\hline Yes & $36.7 \%$ & $49.0 \%$ & $58.8 \%$ & $62.6 \%$ & $46.5 \%$ & $57.3 \%$ & $68.7 \%$ & $66.8 \%$ \\
\hline \multirow[t]{2}{*}{ No } & $63.3 \%$ & $51.0 \%$ & $41.2 \%$ & $37.4 \%$ & $53.5 \%$ & $42.7 \%$ & $31.3 \%$ & $33.2 \%$ \\
\hline & $100.0 \%$ & $100.0 \%$ & $100.0 \%$ & $100.0 \%$ & $100.0 \%$ & $100.0 \%$ & $100.0 \%$ & $100.0 \%$ \\
\hline
\end{tabular}

Note: Area type is no longer available from GHS2005.

Table 10 shows the percentage of people of eligible ages that received child support grants, and the results could be summarized as follows: 
- All: There is a continuous upward trend in the percentage of age-eligible children receiving CSG (i.e., in the coverage rate), from $27.0 \%$ in 2003 to $45.6 \%$ in 2006.

- Province: The coverage rate is the highest (more than $50 \%$ in 2006) in the Eastern Cape, Mpumalanga and Limpopo, but the lowest in Western Cape and Gauteng, reflecting the differences in the preponderance of poverty. The coverage in Western Cape has remained at about 25\% throughout the years, while there has been a slight upward trend in Gauteng. In contrast to these provinces, coverage in provinces where one would expect most poor children to be was initially low due to slow roll-out, but rose very rapidly (e.g. from less than $26 \%$ to over $56 \%$ in Eastern Cape).

- Area type: The coverage rate is much higher in rural areas

- Gender: The coverage has always differed little by gender, and is rising for both boys and girls.

- Race: There is a rising trend in all race groups except whites. Coverage rate is highest for blacks, exceeding $50 \%$ in 2006.

- Attendance at educational institution at the time of the survey: The coverage rate is always higher for those eligible children not attending educational institution at the time of the survey, largely reflecting somewhat better coverage among younger children.

\section{5(c) Household characteristics}

Table 11 shows the household characteristics of the recipients as well as the nonrecipients of child support grants at eligible ages, and Table 12 the coverage rates. The results could be summarised as follows:

- Recipients of CSG come from households with bigger household size on average than non-recipient households with eligible-age children.

- More than 50\% of CSG recipients come from female-headed households. Coverage rates for male and female headed households are quite similar, implying that female headed households constitute the majority of households with age-eligible children.

- More than $80 \%$ of CSG recipients come from households headed by people without Matric. Coverage drops sharply from well over half to just over a quarter for children in households where the head has matric, and to even less for those with higher qualifications. This clearly shows the effect of education on earnings and therefore on eligibility in accordance with the means test.

- More than half of CSG recipients are from households headed by married people, but this proportion is showing a downward trend, complemented by an increasing share of CSG recipients from households headed by unmarried people, from $15 \%$ in 2003 to slightly above $20 \%$ in 2006 . Coverage rates are lower for children from households with married heads, but differ only a little for households with other different marital status, though.

- More than half of the CSG recipients come from households headed by people aged 35-54 years.

- CSG recipients should, per definition, usually not be from single generational households, although a small proportion in fact is. It is noticeable too that twogenerational households are in the majority and that their share has been 
rising, contrary to the view that multigenerational households are the norm. Coverage is somewhat higher amongst multi-generational households.

Table 10

\section{Percentage of eligible children receiving child support grants} by demographic characteristics

\begin{tabular}{|c|c|c|c|c|}
\hline & $\begin{array}{l}\text { GHS } \\
2003\end{array}$ & $\begin{array}{l}\text { GHS } \\
2004\end{array}$ & $\begin{array}{l}\text { GHS } \\
2005\end{array}$ & $\begin{array}{l}\text { GHS } \\
2006\end{array}$ \\
\hline \multicolumn{5}{|c|}{ All } \\
\hline All & $27.0 \%$ & $37.9 \%$ & $40.6 \%$ & $45.6 \%$ \\
\hline \multicolumn{5}{|c|}{ Province } \\
\hline Western Cape & $23.5 \%$ & $26.6 \%$ & $25.4 \%$ & $27.5 \%$ \\
\hline Eastern Cape & $25.8 \%$ & $34.0 \%$ & $46.8 \%$ & $56.3 \%$ \\
\hline Northern Cape & $14.0 \%$ & $34.6 \%$ & $37.2 \%$ & $39.0 \%$ \\
\hline Free State & $34.3 \%$ & $42.9 \%$ & $47.0 \%$ & $49.4 \%$ \\
\hline KwaZulu-Natal & $21.6 \%$ & $33.5 \%$ & $38.4 \%$ & $43.5 \%$ \\
\hline North West & $29.6 \%$ & $45.9 \%$ & $40.6 \%$ & $48.4 \%$ \\
\hline Gauteng & $19.3 \%$ & $26.8 \%$ & $29.1 \%$ & $32.2 \%$ \\
\hline Mpumalanga & $38.3 \%$ & $48.4 \%$ & $47.9 \%$ & $54.8 \%$ \\
\hline Limpopo & $39.7 \%$ & $55.9 \%$ & $51.4 \%$ & $54.2 \%$ \\
\hline \multicolumn{5}{|c|}{ Area type } \\
\hline Urban & $21.9 \%$ & $29.9 \%$ & $\mathrm{n} / \mathrm{a}$ & $\mathrm{n} / \mathrm{a}$ \\
\hline Rural & $31.7 \%$ & $44.7 \%$ & $\mathrm{n} / \mathrm{a}$ & $\mathrm{n} / \mathrm{a}$ \\
\hline \multicolumn{5}{|c|}{ Gender } \\
\hline Male & $26.6 \%$ & $37.4 \%$ & $40.4 \%$ & $45.1 \%$ \\
\hline Female & $27.4 \%$ & $38.4 \%$ & $40.9 \%$ & $46.2 \%$ \\
\hline \multicolumn{5}{|c|}{ Race } \\
\hline Black & $30.8 \%$ & $43.0 \%$ & $45.5 \%$ & $51.1 \%$ \\
\hline Coloured & $16.0 \%$ & $24.1 \%$ & $25.0 \%$ & $26.6 \%$ \\
\hline Indian & $2.3 \%$ & $5.8 \%$ & $12.6 \%$ & $16.6 \%$ \\
\hline White & $0.8 \%$ & $0.3 \%$ & $0.8 \%$ & $0.8 \%$ \\
\hline \multicolumn{5}{|c|}{ Attendance at educational institution at the time of the survey } \\
\hline Yes & $22.6 \%$ & $34.2 \%$ & $36.9 \%$ & $44.0 \%$ \\
\hline No & $30.4 \%$ & $42.1 \%$ & $47.3 \%$ & $48.6 \%$ \\
\hline
\end{tabular}

Note: Area type is no longer available from GHS2005. 


\section{Table 11}

\section{Household characteristics of the recipients and non-recipients}

of child support grants at eligible ages

\begin{tabular}{|c|c|c|c|c|c|c|c|c|}
\hline & \multicolumn{4}{|c|}{$\begin{array}{l}\text { Eligible age + } \\
\text { received CSG }\end{array}$} & \multicolumn{4}{|c|}{$\begin{array}{c}\text { Eligible age + } \\
\text { did NOT receive CSG }\end{array}$} \\
\hline & $\begin{array}{l}\text { GHS } \\
2003\end{array}$ & $\begin{array}{l}\text { GHS } \\
2004\end{array}$ & $\begin{array}{l}\text { GHS } \\
2005\end{array}$ & $\begin{array}{l}\text { GHS } \\
2006 \\
\end{array}$ & $\begin{array}{l}\text { GHS } \\
2003\end{array}$ & $\begin{array}{l}\text { GHS } \\
2004 \\
\end{array}$ & $\begin{array}{l}\text { GHS } \\
2005 \\
\end{array}$ & $\begin{array}{l}\text { GHS } \\
2006 \\
\end{array}$ \\
\hline \multicolumn{9}{|c|}{ Household size } \\
\hline Mean & 6.53 & 6.46 & 6.47 & 6.29 & 6.16 & 6.23 & 5.97 & 5.78 \\
\hline Std Dev. & 2.77 & 2.76 & 2.79 & 2.67 & 2.84 & 3.07 & 2.62 & 2.50 \\
\hline \multicolumn{9}{|c|}{ Gender of household head } \\
\hline Male & $44.1 \%$ & $42.5 \%$ & $44.1 \%$ & $42.6 \%$ & $56.9 \%$ & $57.6 \%$ & $56.7 \%$ & $57.0 \%$ \\
\hline Female & $55.9 \%$ & $57.5 \%$ & $55.9 \%$ & $57.4 \%$ & $43.1 \%$ & $42.4 \%$ & $43.3 \%$ & $43.0 \%$ \\
\hline & $100.0 \%$ & $100.0 \%$ & $100.0 \%$ & $100.0 \%$ & $100.0 \%$ & $100.0 \%$ & $100.0 \%$ & $100.0 \%$ \\
\hline \multicolumn{9}{|c|}{ Race of household head } \\
\hline Black & $94.5 \%$ & $94.0 \%$ & $94.2 \%$ & $94.4 \%$ & $78.6 \%$ & $75.9 \%$ & $77.1 \%$ & $76.1 \%$ \\
\hline Coloure & $.2 \%$ & $5.7 \%$ & $5.1 \%$ & $4.8 \%$ & $10.0 \%$ & $10.7 \%$ & $10.5 \%$ & $11.0 \%$ \\
\hline Indian & $0.2 \%$ & $0.3 \%$ & $0.5 \%$ & $0.7 \%$ & $2.4 \%$ & $2.7 \%$ & $2.8 \%$ & $2.8 \%$ \\
\hline White & $0.2 \%$ & $0.1 \%$ & $0.2 \%$ & $0.1 \%$ & $9.0 \%$ & $10.7 \%$ & $9.6 \%$ & $10.1 \%$ \\
\hline & $100.0 \%$ & $100.0 \%$ & $100.0 \%$ & $100.0 \%$ & $100.0 \%$ & $100.0 \%$ & $100.0 \%$ & $100.0 \%$ \\
\hline \multicolumn{9}{|c|}{ Highest educational attainment of household head } \\
\hline No sch & $26.5 \%$ & $26.5 \%$ & $25.8 \%$ & $26.2 \%$ & $20.4 \%$ & $20.0 \%$ & $19.9 \%$ & $17.2 \%$ \\
\hline Inco & $27.3 \%$ & $27.6 \%$ & $27.4 \%$ & $26.2 \%$ & $21.7 \%$ & $21.7 \%$ & $20.4 \%$ & $19.2 \%$ \\
\hline Incomp & $38.4 \%$ & $36.6 \%$ & $37.1 \%$ & $38.4 \%$ & $35.8 \%$ & $32.2 \%$ & $32.8 \%$ & $34.8 \%$ \\
\hline Matric & $6.1 \%$ & $7.7 \%$ & $8.2 \%$ & $8.0 \%$ & $13.5 \%$ & $14.6 \%$ & $15.7 \%$ & $18.0 \%$ \\
\hline Matric & $1.2 \%$ & $1.3 \%$ & $1.3 \%$ & $0.8 \%$ & $3.7 \%$ & $6.3 \%$ & $6.5 \%$ & $6.1 \%$ \\
\hline Degree & $0.6 \%$ & $0.3 \%$ & $0.2 \%$ & $0.3 \%$ & $4.9 \%$ & $5.3 \%$ & $4.7 \%$ & $4.8 \%$ \\
\hline & $100.0 \%$ & $100.0 \%$ & $100.0 \%$ & $100.0 \%$ & $100.0 \%$ & $100.0 \%$ & $100.0 \%$ & $100.0 \%$ \\
\hline \multicolumn{9}{|c|}{ Marital status of household head } \\
\hline Mar & $57.3 \%$ & $55.1 \%$ & $52.9 \%$ & $52.3 \%$ & $64.7 \%$ & $64.5 \%$ & $62.9 \%$ & $63.6 \%$ \\
\hline Widow/W & $22.9 \%$ & $23.4 \%$ & $23.6 \%$ & $22.4 \%$ & $19.1 \%$ & $19.6 \%$ & $18.3 \%$ & $16.3 \%$ \\
\hline Divorc & $4.5 \%$ & $5.2 \%$ & $4.8 \%$ & $4.2 \%$ & $4.2 \%$ & $4.3 \%$ & $4.2 \%$ & $3.9 \%$ \\
\hline Unmarried & $15.2 \%$ & $16.3 \%$ & $18.7 \%$ & $21.1 \%$ & $12.1 \%$ & $11.6 \%$ & $14.6 \%$ & $16.2 \%$ \\
\hline & $100.0 \%$ & $100.0 \%$ & $100.0 \%$ & $100.0 \%$ & $100.0 \%$ & $100.0 \%$ & $100.0 \%$ & $100.0 \%$ \\
\hline \multicolumn{9}{|c|}{ Age of household head } \\
\hline Under 18 ye & $0.1 \%$ & $0.3 \%$ & $0.2 \%$ & $0.2 \%$ & $0.2 \%$ & $0.3 \%$ & $0.4 \%$ & $0.5 \%$ \\
\hline 18-24 years & $2.2 \%$ & $3.0 \%$ & $2.4 \%$ & $2.6 \%$ & $2.1 \%$ & $2.1 \%$ & $2.1 \%$ & $2.5 \%$ \\
\hline 25-34 years & $16.7 \%$ & $16.1 \%$ & $18.7 \%$ & $17.9 \%$ & $20.2 \%$ & $19.4 \%$ & $17.9 \%$ & $18.4 \%$ \\
\hline $35-44$ years & $24.7 \%$ & $24.1 \%$ & $23.7 \%$ & $24.4 \%$ & $28.8 \%$ & $27.7 \%$ & $29.6 \%$ & $30.0 \%$ \\
\hline $45-54$ years & $21.0 \%$ & $21.2 \%$ & $21.7 \%$ & $21.0 \%$ & $18.7 \%$ & $19.1 \%$ & $21.2 \%$ & $21.2 \%$ \\
\hline $55-64$ years & $17.4 \%$ & $17.9 \%$ & $15.8 \%$ & $15.7 \%$ & $14.3 \%$ & $15.0 \%$ & $14.2 \%$ & $13.7 \%$ \\
\hline $65+$ years & $17.9 \%$ & $17.5 \%$ & $17.4 \%$ & $18.2 \%$ & $15.7 \%$ & $16.3 \%$ & $14.5 \%$ & $13.6 \%$ \\
\hline & $100.0 \%$ & $100.0 \%$ & $100.0 \%$ & $100.0 \%$ & $100.0 \%$ & $100.0 \%$ & $100.0 \%$ & $100.0 \%$ \\
\hline \multicolumn{9}{|c|}{ Number of generations in the household } \\
\hline One & $3.1 \%$ & $3.0 \%$ & $3.5 \%$ & $3.5 \%$ & $2.7 \%$ & $2.5 \%$ & $3.9 \%$ & $4.0 \%$ \\
\hline Two & $49.7 \%$ & $52.0 \%$ & $54.1 \%$ & $55.5 \%$ & $60.5 \%$ & $61.0 \%$ & $62.5 \%$ & $64.9 \%$ \\
\hline Three & $46.3 \%$ & $44.2 \%$ & $41.5 \%$ & $40.3 \%$ & $36.4 \%$ & $36.1 \%$ & $32.8 \%$ & $30.6 \%$ \\
\hline \multirow[t]{2}{*}{ Four/Five } & $0.9 \%$ & $0.8 \%$ & $0.9 \%$ & $0.7 \%$ & $0.4 \%$ & $0.5 \%$ & $0.9 \%$ & $0.5 \%$ \\
\hline & $100.0 \%$ & $100.0 \%$ & $100.0 \%$ & $100.0 \%$ & $100.0 \%$ & $100.0 \%$ & $100.0 \%$ & $100.0 \%$ \\
\hline
\end{tabular}

In addition, Table 12 shows the percentage of people in eligible ages that received CSG, and the results show the children coming from households headed by Blacks, without Matric, widowed or unmarried, and with more than two generations of people living together are more likely to receive CSG. 
Table 12

Percentage of eligible children receiving child support grants by household characteristics

\begin{tabular}{|c|c|c|c|c|}
\hline & $\begin{array}{l}\text { GHS } \\
2003\end{array}$ & $\begin{array}{l}\text { GHS } \\
2004\end{array}$ & $\begin{array}{l}\text { GHS } \\
2005\end{array}$ & $\begin{array}{l}\text { GHS } \\
2006\end{array}$ \\
\hline \multicolumn{5}{|c|}{ Gender of household head } \\
\hline Male & $26.6 \%$ & $37.4 \%$ & $40.4 \%$ & $45.1 \%$ \\
\hline Female & $27.4 \%$ & $38.4 \%$ & $40.9 \%$ & $46.2 \%$ \\
\hline \multicolumn{5}{|c|}{ Race of household head } \\
\hline Black & $30.8 \%$ & $43.0 \%$ & $45.5 \%$ & $51.1 \%$ \\
\hline Coloured & $16.0 \%$ & $24.1 \%$ & $25.0 \%$ & $26.6 \%$ \\
\hline Indian & $2.3 \%$ & $5.8 \%$ & $12.6 \%$ & $16.6 \%$ \\
\hline White & $0.8 \%$ & $0.3 \%$ & $0.8 \%$ & $0.8 \%$ \\
\hline \multicolumn{5}{|c|}{ Highest educational attainment of household head } \\
\hline No schooling & $32.4 \%$ & $44.6 \%$ & $47.0 \%$ & $56.1 \%$ \\
\hline Incomplete prim. & $31.8 \%$ & $43.6 \%$ & $47.9 \%$ & $53.5 \%$ \\
\hline Incomplete sec. & $28.4 \%$ & $40.9 \%$ & $43.6 \%$ & $48.1 \%$ \\
\hline Matric & $14.2 \%$ & $24.3 \%$ & $26.3 \%$ & $27.2 \%$ \\
\hline Matric + Cert/Dip & $10.6 \%$ & $11.1 \%$ & $12.2 \%$ & $10.3 \%$ \\
\hline Degree & $4.0 \%$ & $3.4 \%$ & $2.9 \%$ & $5.4 \%$ \\
\hline \multicolumn{5}{|c|}{ Marital status of household head } \\
\hline Married & $24.7 \%$ & $34.2 \%$ & $36.5 \%$ & $40.8 \%$ \\
\hline Widow/Widower & $30.8 \%$ & $42.1 \%$ & $46.8 \%$ & $53.6 \%$ \\
\hline Divorced/Separated & $28.4 \%$ & $42.7 \%$ & $43.7 \%$ & $47.7 \%$ \\
\hline Unmarried & $31.9 \%$ & $46.1 \%$ & $46.8 \%$ & $52.2 \%$ \\
\hline \multicolumn{5}{|c|}{ Age of household head } \\
\hline Under 18 years & $9.9 \%$ & $37.2 \%$ & $23.7 \%$ & $27.3 \%$ \\
\hline $18-24$ years & $28.0 \%$ & $45.7 \%$ & $43.0 \%$ & $46.5 \%$ \\
\hline $25-34$ years & $23.4 \%$ & $33.6 \%$ & $41.7 \%$ & $45.0 \%$ \\
\hline $35-44$ years & $24.1 \%$ & $34.6 \%$ & $35.4 \%$ & $40.6 \%$ \\
\hline $45-54$ years & $29.4 \%$ & $40.3 \%$ & $41.2 \%$ & $45.4 \%$ \\
\hline $55-64$ years & $31.1 \%$ & $42.0 \%$ & $43.3 \%$ & $49.0 \%$ \\
\hline $65+$ years & $29.8 \%$ & $39.5 \%$ & $45.1 \%$ & $52.9 \%$ \\
\hline \multicolumn{5}{|c|}{ Number of generations in the household } \\
\hline One & $29.7 \%$ & $41.7 \%$ & $38.2 \%$ & $42.3 \%$ \\
\hline Two & $23.3 \%$ & $34.2 \%$ & $37.2 \%$ & $41.8 \%$ \\
\hline Three & $32.0 \%$ & $42.7 \%$ & $46.4 \%$ & $52.5 \%$ \\
\hline Four/Five & $45.2 \%$ & $51.7 \%$ & $40.9 \%$ & $52.8 \%$ \\
\hline
\end{tabular}




\section{5(d) Labour market}

Table 13 shows that the share of inactive household heads is larger among households with eligible-age children who do receive grants than those who do not, indicating that employed household heads are more likely to be disqualified in accordance with the means test. The number of employed household members is only just above two-thirds on average in households receiving grants (which, as has been shown, are usually larger households), whereas it is almost 1 amongst non-recipient households with age-eligible children. The number of household heads who are broadly unemployed has dropped both among recipient and non-recipient households with age-eligible children.

Figure 18 shows the percentage of age-eligible children receiving grants has increased for all employment status categories of households head, indicating broad expansion of the grant and not more targeting on poorer households.

\section{Table 13}

\section{Labour market characteristics of the recipients and non-recipients} of child support grants

\begin{tabular}{|c|c|c|c|c|c|c|c|c|}
\hline & \multicolumn{4}{|c|}{$\begin{array}{l}\text { Eligible age + } \\
\text { received CSG }\end{array}$} & \multicolumn{4}{|c|}{$\begin{array}{c}\text { Eligible age + } \\
\text { did NOT receive CSG }\end{array}$} \\
\hline & GHS & GHS & GHS & GHS & GHS & GHS & GHS & GHS \\
\hline & 2003 & 2004 & 2005 & 2006 & 2003 & 2004 & 2005 & 2006 \\
\hline \multicolumn{9}{|c|}{ Broad employment status of household head } \\
\hline Inactive & $41.5 \%$ & $41.0 \%$ & $41.9 \%$ & $41.5 \%$ & $32.8 \%$ & $34.5 \%$ & $32.1 \%$ & $31.0 \%$ \\
\hline Employed & $35.9 \%$ & $36.0 \%$ & $35.8 \%$ & $36.2 \%$ & $52.0 \%$ & $52.7 \%$ & $54.6 \%$ & $55.8 \%$ \\
\hline \multirow[t]{2}{*}{ Unemployed } & $22.6 \%$ & $23.0 \%$ & $22.4 \%$ & $22.3 \%$ & $15.2 \%$ & $12.8 \%$ & $13.3 \%$ & $13.2 \%$ \\
\hline & $100.0 \%$ & $100.0 \%$ & $100.0 \%$ & $100.0 \%$ & $100.0 \%$ & $100.0 \%$ & $100.0 \%$ & $100.0 \%$ \\
\hline \multicolumn{9}{|c|}{ Number of employed in the household } \\
\hline Mean & 0.68 & 0.68 & 0.67 & 0.69 & 0.95 & 1.00 & 1.03 & 1.04 \\
\hline Std Dev. & 0.84 & 0.83 & 0.83 & 0.83 & 0.90 & 0.92 & 0.93 & 0.92 \\
\hline \multicolumn{9}{|c|}{ Number of narrow unemployed in the household } \\
\hline Mean & 0.63 & 0.58 & 0.60 & 0.59 & 0.51 & 0.50 & 0.41 & 0.45 \\
\hline Std Dev. & 0.99 & 0.93 & 0.94 & 0.94 & 0.94 & 1.00 & 0.79 & 0.90 \\
\hline \multicolumn{9}{|c|}{ Number of broad unemployed in the household head } \\
\hline Mean & 1.28 & 1.22 & 1.18 & 1.08 & 1.00 & 0.96 & 0.82 & 0.79 \\
\hline Std Dev. & 1.29 & 1.22 & 1.18 & 1.10 & 1.21 & 1.32 & 1.09 & 1.06 \\
\hline
\end{tabular}

In addition, Figure 18 below shows that eligible children coming from households headed by inactive or unemployed people are more likely to receive child support grants, as these proportions have exceed $50 \%$ throughout the years. 
Figure 18

Proportion of eligible children receiving child support grants, by broad employment status of household head

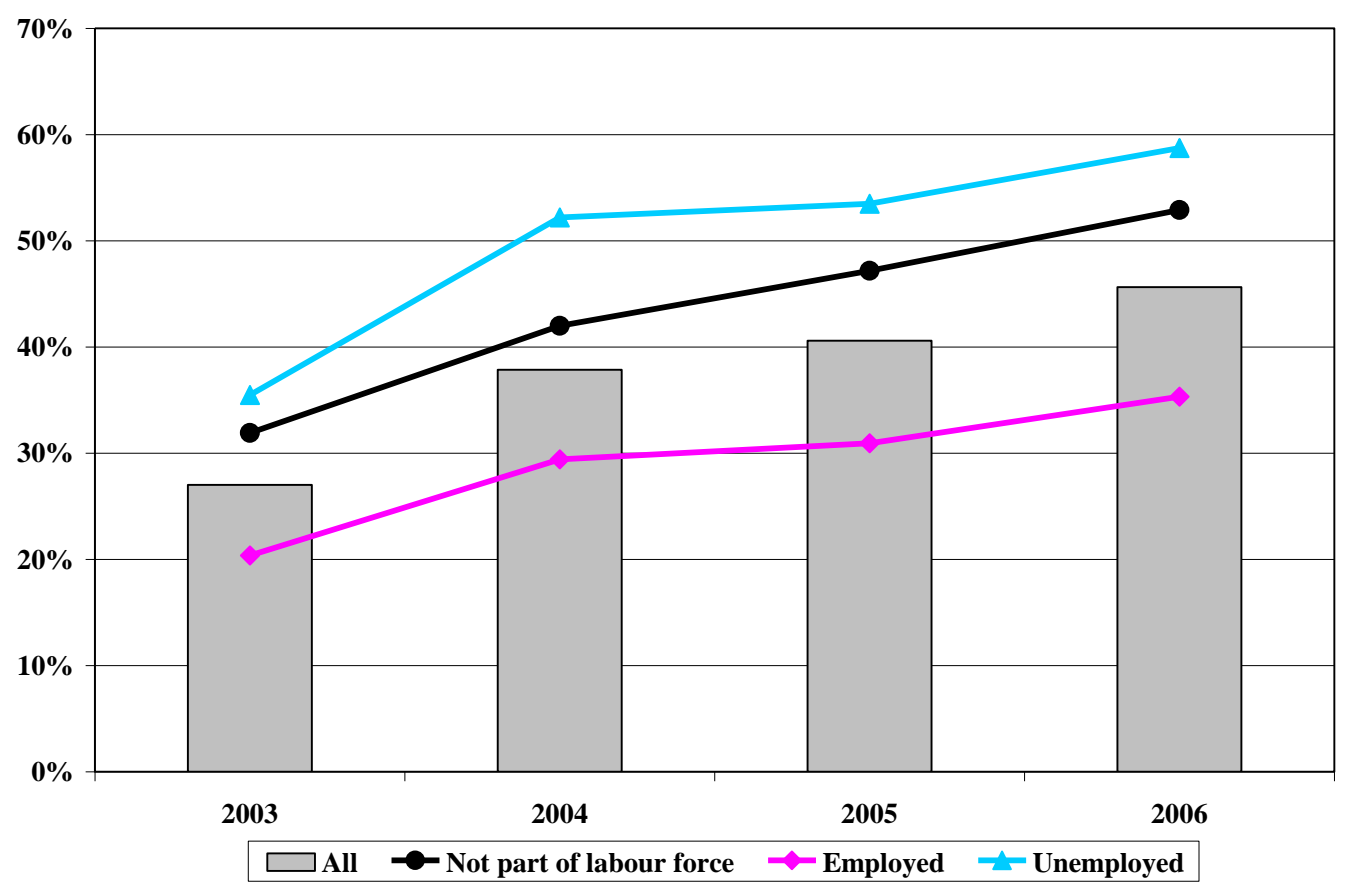

\section{5(e) Hunger}

Table 14 shows that the proportion of households reporting that children went hungry in the year before the survey declined strongly for both recipients and non-recipient households with age-eligible children, from 56.5\% in 2002 to $76.9 \%$ in 2006 and from $69.0 \%$ to $84.7 \%$ respectively. It nevertheless remains surprising that more than $15 \%$ of age-eligible households reporting that children have gone hungry in the past year in 2006 still did not get the CSG. This may point to some over-reporting of child hunger, to temporary episodes of want (although $1.0 \%$ of such households still did report that children always went hungry), or to the means test or administrative constraints leading to errors of exclusion (poor children not being targeted). This issue deserves further investigation, though the more lenient means test should assist if the means test was the problem. Also, the expansion of the grant has reduced the proportion of non-recipient households with age-eligible children not receiving grants from $33 \%$ to $15 \%$, indicating improved de facto targeting.

\section{5(f) Living conditions}

The worsening of living conditions amongst recipient households (Table 15) implies not a worsening of conditions per se, but rather that the expansion of the grants (e.g. in the Eastern Cape) has be accompanied by better targeting to households with poor living conditions as the roll out of the grants improved. So, for instance, in GHS2003 only $32.4 \%$ of recipients had no tap in the house or on site, but in GHS2006 this figure was $56.7 \%$. 
Table 14

Household child and adult hunger frequency by the recipients and non-recipients of child support grants at eligible ages

\begin{tabular}{|l|r|r|r|r|r|r|r|r|r|}
\hline & \multicolumn{4}{|c|}{$\begin{array}{r}\text { Eligible age } \\
\text { received CSG }\end{array}$} & \multicolumn{4}{|c|}{ Eligible age + } \\
& GHS & GHS & GHS & GHS & GHS & GHS & GHS \\
2003 & 2004 & 2005 & 2006 & 2003 & GHS \\
2004 & 2005 & 2006 \\
\hline Child hunger: Proportion of households reporting that a child went hungry in the past year \\
\hline Never & $56.5 \%$ & $64.4 \%$ & $67.1 \%$ & $76.9 \%$ & $69.0 \%$ & $72.7 \%$ & $77.2 \%$ & $84.7 \%$ \\
\hline Seldom & $7.7 \%$ & $6.6 \%$ & $6.0 \%$ & $3.3 \%$ & $5.0 \%$ & $5.1 \%$ & $4.2 \%$ & $2.9 \%$ \\
\hline Sometimes & $24.5 \%$ & $22.3 \%$ & $20.1 \%$ & $16.4 \%$ & $18.4 \%$ & $16.4 \%$ & $13.7 \%$ & $10.2 \%$ \\
\hline Often & $6.8 \%$ & $4.3 \%$ & $3.8 \%$ & $2.0 \%$ & $4.5 \%$ & $3.5 \%$ & $2.7 \%$ & $1.4 \%$ \\
\hline Always & $4.5 \%$ & $2.4 \%$ & $3.0 \%$ & $1.4 \%$ & $3.1 \%$ & $2.3 \%$ & $2.3 \%$ & $0.9 \%$ \\
\hline & $100.0 \%$ & $100.0 \%$ & $100.0 \%$ & $100.0 \%$ & $100.0 \%$ & $100.0 \%$ & $100.0 \%$ & $100.0 \%$ \\
\hline Child hunger: Proportion of households reporting that an adult went hungry in the past year \\
\hline Never & $54.9 \%$ & $62.7 \%$ & $65.7 \%$ & $76.4 \%$ & $67.0 \%$ & $71.7 \%$ & $76.1 \%$ & $84.2 \%$ \\
\hline Seldom & $8.3 \%$ & $6.5 \%$ & $6.2 \%$ & $3.6 \%$ & $5.5 \%$ & $4.8 \%$ & $4.3 \%$ & $3.1 \%$ \\
\hline Sometimes & $26.3 \%$ & $22.6 \%$ & $20.8 \%$ & $16.3 \%$ & $19.5 \%$ & $16.8 \%$ & $14.2 \%$ & $10.2 \%$ \\
\hline Often & $6.1 \%$ & $4.8 \%$ & $4.2 \%$ & $2.3 \%$ & $4.9 \%$ & $3.5 \%$ & $2.9 \%$ & $1.5 \%$ \\
\hline Always & $4.4 \%$ & $3.4 \%$ & $3.1 \%$ & $1.5 \%$ & $3.1 \%$ & $3.3 \%$ & $2.5 \%$ & $1.0 \%$ \\
\hline & $100.0 \%$ & $100.0 \%$ & $100.0 \%$ & $100.0 \%$ & $100.0 \%$ & $100.0 \%$ & $100.0 \%$ & $100.0 \%$ \\
\hline
\end{tabular}

\section{$5(\mathrm{~g}) \quad$ Income and expenditure}

Table 16 below shows that there is an increasing trend in the proportion of CSG recipients having pensions/grants as the main income source of the household (increasing from $38.0 \%$ in 2003 to $49.0 \%$ in 2006), but this proportion remains at approximately $25 \%$ for non-recipients. A majority of non-recipients claim that salaries and wages are the main income sources of the household. Additionally, Table 17 shows that nearly $70 \%$ of the recipients of child support grants come from households with monthly expenditure less than R1200 per month, while this proportion is only slightly above $50 \%$ in the case of the non-recipients. Furthermore, Table 17 shows that children coming from households spending less than R1200 per month or having pensions/grants as the main household income source are more likely to receive child support grants. It should be noted that the monthly household expenditure categories shown in Table 17 are constant in nominal terms, implying a tightening in real terms of the criteria, as also applied to the means test. (It should also be noted that household size is not considered.) As is to be expected, coverage has expanded in all expenditure ranges The fact that coverage is still only $60 \%$ in the bottom-most category is surprising, and may perhaps be due to non-recipient households in this category being smaller households, but given the means test, one would expect all households in at least the bottom two or three categories to qualify in accordance to receive grants, if these expenditures were accurately recorded. 
Table 15

Percentage of eligible children receiving child support grants by living conditions

\begin{tabular}{|c|c|c|c|c|}
\hline & GHS2003 & GHS2004 & GHS2005 & GHS2006 \\
\hline \multicolumn{5}{|c|}{ Dwelling type } \\
\hline Formal & $25.5 \%$ & $35.5 \%$ & $36.6 \%$ & $41.3 \%$ \\
\hline Informal & $30.7 \%$ & $42.9 \%$ & $48.6 \%$ & $56.0 \%$ \\
\hline \multicolumn{5}{|c|}{ Water access } \\
\hline Piped (Tap) water in dwelling & $14.2 \%$ & $18.9 \%$ & $21.6 \%$ & $24.7 \%$ \\
\hline Piper (Tap) water on site or in yard & $32.8 \%$ & $46.9 \%$ & $47.4 \%$ & $52.3 \%$ \\
\hline $\begin{array}{l}\text { No tap in dwelling or on site (Public } \\
\text { tap, or Others) }\end{array}$ & $32.4 \%$ & $44.7 \%$ & $49.4 \%$ & $56.7 \%$ \\
\hline \multicolumn{5}{|c|}{ Sanitation } \\
\hline Flush/Chemical toilet & $19.6 \%$ & $26.5 \%$ & $28.7 \%$ & $31.7 \%$ \\
\hline Pit latrine with / without ventilation & $31.9 \%$ & $46.8 \%$ & $49.8 \%$ & $55.8 \%$ \\
\hline Bucket toilet/None & $34.3 \%$ & $43.5 \%$ & $50.3 \%$ & $60.4 \%$ \\
\hline \multicolumn{5}{|c|}{ Fuel for cooking } \\
\hline Electricity/Solar & $19.5 \%$ & $28.4 \%$ & $30.8 \%$ & $35.3 \%$ \\
\hline Paraffin & $33.3 \%$ & $46.5 \%$ & $50.7 \%$ & $57.3 \%$ \\
\hline Wood & $33.9 \%$ & $46.4 \%$ & $50.4 \%$ & $58.0 \%$ \\
\hline Others/None & $33.1 \%$ & $43.4 \%$ & $47.8 \%$ & $54.5 \%$ \\
\hline \multicolumn{5}{|c|}{ Refuse removal } \\
\hline Removed at least once a week & $21.2 \%$ & $28.8 \%$ & $31.4 \%$ & $34.4 \%$ \\
\hline Removed less than once a week & $17.9 \%$ & $39.3 \%$ & $43.1 \%$ & $41.8 \%$ \\
\hline Communal refuse dump & $29.2 \%$ & $33.0 \%$ & $48.4 \%$ & $56.1 \%$ \\
\hline Own refuse dump & $32.9 \%$ & $45.8 \%$ & $48.8 \%$ & $56.4 \%$ \\
\hline Others/None & $21.4 \%$ & $40.2 \%$ & $46.4 \%$ & $53.9 \%$ \\
\hline \multicolumn{5}{|c|}{ Availability of telephone } \\
\hline Yes & $12.4 \%$ & $15.5 \%$ & $16.0 \%$ & $19.7 \%$ \\
\hline No & $30.1 \%$ & $42.2 \%$ & $44.8 \%$ & $49.7 \%$ \\
\hline \multicolumn{5}{|c|}{ Availability of cell phones } \\
\hline Yes & $22.8 \%$ & $33.3 \%$ & $37.2 \%$ & $43.2 \%$ \\
\hline No & $29.8 \%$ & $42.3 \%$ & $46.6 \%$ & $51.7 \%$ \\
\hline
\end{tabular}

Table 19 and Figure 19 show the coverage rate by deciles of mean earnings (i.e. of employed household heads). It is clear that for this sub-group there is quite good targeting, in that the poorest deciles are far better covered, and that the expansion of the CSG over the years has improved the coverage at the bottom end of the earnings distribution. 
Table 16

Household income and expenditure information by child support grant receipt status

\begin{tabular}{|l|r|r|r|r|r|r|r|r|}
\hline & \multicolumn{7}{|c|}{ Eligible age + received CSG } & \multicolumn{2}{|c|}{ Eligible age + did NOT receive CSG } \\
\hline & $\begin{array}{r}\text { GHS } \\
2003\end{array}$ & $\begin{array}{r}\text { GHS } \\
2004\end{array}$ & $\begin{array}{r}\text { GHS } \\
2005\end{array}$ & $\begin{array}{r}\text { GHS } \\
2006\end{array}$ & $\begin{array}{r}\text { GHS } \\
2003\end{array}$ & $\begin{array}{r}\text { GHS } \\
2004\end{array}$ & $\begin{array}{r}\text { GHS } \\
2005\end{array}$ & $\begin{array}{r}\text { GHS } \\
2006\end{array}$ \\
\hline Salaries/Wages & $34.2 \%$ & $32.8 \%$ & $34.4 \%$ & $34.5 \%$ & $53.8 \%$ & $53.7 \%$ & $57.5 \%$ & $59.5 \%$ \\
\hline Remittances & $19.5 \%$ & $19.0 \%$ & $12.8 \%$ & $11.9 \%$ & $16.0 \%$ & $13.7 \%$ & $12.1 \%$ & $11.2 \%$ \\
\hline Pensions/Grants & $38.0 \%$ & $40.9 \%$ & $46.8 \%$ & $49.0 \%$ & $23.6 \%$ & $26.2 \%$ & $24.3 \%$ & $24.5 \%$ \\
\hline Sales of farm products & $0.9 \%$ & $0.8 \%$ & $1.0 \%$ & $1.3 \%$ & $0.9 \%$ & $1.0 \%$ & $0.8 \%$ & $1.2 \%$ \\
\hline Other non-farm income & $6.3 \%$ & $6.3 \%$ & $4.5 \%$ & $2.8 \%$ & $4.0 \%$ & $4.7 \%$ & $3.8 \%$ & $2.4 \%$ \\
\hline No income & $1.2 \%$ & $0.3 \%$ & $0.6 \%$ & $0.5 \%$ & $1.7 \%$ & $0.8 \%$ & $1.4 \%$ & $1.3 \%$ \\
\hline & $100.0 \%$ & $100.0 \%$ & $100.0 \%$ & $100.0 \%$ & $100.0 \%$ & $100.0 \%$ & $100.0 \%$ & $100.0 \%$ \\
\hline Monthly household expenditure (Rand, nominal values) \\
\hline R0-R399 & $30.7 \%$ & $20.5 \%$ & $22.1 \%$ & $20.2 \%$ & $23.0 \%$ & $14.1 \%$ & $13.7 \%$ & $11.3 \%$ \\
\hline R400-R799 & $38.7 \%$ & $40.6 \%$ & $40.6 \%$ & $40.8 \%$ & $30.5 \%$ & $28.5 \%$ & $28.0 \%$ & $27.5 \%$ \\
\hline R800-R1 199 & $17.9 \%$ & $20.8 \%$ & $19.3 \%$ & $22.3 \%$ & $16.3 \%$ & $15.7 \%$ & $15.2 \%$ & $17.6 \%$ \\
\hline R1 200-R1 799 & $6.7 \%$ & $10.3 \%$ & $9.9 \%$ & $9.4 \%$ & $8.2 \%$ & $11.7 \%$ & $11.9 \%$ & $12.6 \%$ \\
\hline R1 800-R2 499 & $3.7 \%$ & $4.6 \%$ & $4.6 \%$ & $4.0 \%$ & $5.5 \%$ & $7.4 \%$ & $7.6 \%$ & $8.1 \%$ \\
\hline R2 500-R4 999 & $2.0 \%$ & $2.8 \%$ & $2.9 \%$ & $2.9 \%$ & $8.4 \%$ & $11.6 \%$ & $12.4 \%$ & $11.0 \%$ \\
\hline R5 000-R9 999 & $0.4 \%$ & $0.4 \%$ & $0.5 \%$ & $0.4 \%$ & $5.4 \%$ & $7.8 \%$ & $7.7 \%$ & $8.2 \%$ \\
\hline R10 000+ & $0.0 \%$ & $0.1 \%$ & $0.1 \%$ & $0.1 \%$ & $2.8 \%$ & $3.2 \%$ & $3.4 \%$ & $3.9 \%$ \\
\hline & $100.0 \%$ & $100.0 \%$ & $100.0 \%$ & $100.0 \%$ & $100.0 \%$ & $100.0 \%$ & $100.0 \%$ & $100.0 \%$ \\
\hline
\end{tabular}

Table 17

Percentage of eligible children receiving child support grants by monthly household expenditure

\begin{tabular}{|l|r|r|r|r|}
\hline & GHS2003 & GHS2004 & GHS2005 & GHS2006 \\
\hline \multicolumn{4}{|c|}{ Monthly household expenditure (Rand, nominal values) } \\
\hline R0-R399 & $33.7 \%$ & $47.2 \%$ & $52.7 \%$ & $60.1 \%$ \\
\hline R400-R799 & $32.5 \%$ & $46.8 \%$ & $50.0 \%$ & $55.7 \%$ \\
\hline R800-R1 199 & $29.5 \%$ & $44.9 \%$ & $46.7 \%$ & $51.8 \%$ \\
\hline R1 200-R1 799 & $23.8 \%$ & $35.4 \%$ & $36.3 \%$ & $38.7 \%$ \\
\hline R1 800-R2 499 & $20.3 \%$ & $27.6 \%$ & $29.6 \%$ & $29.3 \%$ \\
\hline R2 500-R4 999 & $8.1 \%$ & $12.8 \%$ & $13.8 \%$ & $18.4 \%$ \\
\hline R5 000-R9 999 & $2.5 \%$ & $2.9 \%$ & $4.6 \%$ & $3.8 \%$ \\
\hline R10 000+ & $0.0 \%$ & $1.5 \%$ & $1.5 \%$ & $2.6 \%$ \\
\hline
\end{tabular}


Table 18

CSG coverage by earnings decile of the employed

\begin{tabular}{|c|c|c|c|c|c|c|c|c|c|c|c|}
\hline & $\begin{array}{l}\overline{0} \\
\frac{\overline{0}}{\bar{d}} \\
\bar{\Delta}\end{array}$ & $\begin{array}{l}\text { N } \\
\stackrel{0}{\bar{J}} \\
\stackrel{\Xi}{\Delta}\end{array}$ & 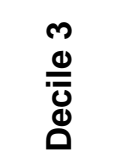 & 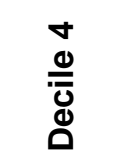 & 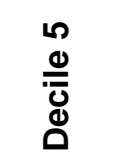 & 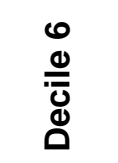 & 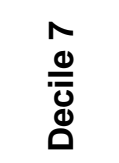 & $\begin{array}{l}\infty \\
\mathbb{0} \\
\overline{0} \\
\Phi \\
\end{array}$ & 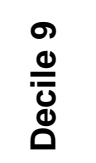 & $\begin{array}{l}\frac{O}{0} \\
\frac{0}{\bar{J}} \\
\stackrel{0}{0}\end{array}$ & $\overline{\bar{\alpha}}$ \\
\hline GHS & $3.3 \%$ & $2.5 \%$ & $2.2 \%$ & $20.2 \%$ & & $5.1 \%$ & 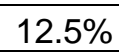 & & $2.9 \%$ & $2.6 \%$ & $16.1 \%$ \\
\hline GHS2003 & $47.8 \%$ & $40.0 \%$ & $38.5 \%$ & $37.1 \%$ & $31.8 \%$ & $27.0 \%$ & $23.7 \%$ & 14. & $6.0 \%$ & $2.2 \%$ & $28.3 \%$ \\
\hline GHS2004 & $57.4 \%$ & $56.4 \%$ & $55.4 \%$ & $50.3 \%$ & $42.0 \%$ & $33.3 \%$ & $28.3 \%$ & $15.6 \%$ & $7.7 \%$ & $3.1 \%$ & $36.6 \%$ \\
\hline GHS2005 & $65.2 \%$ & $58.4 \%$ & $54.5 \%$ & $47.7 \%$ & $44.8 \%$ & $35.2 \%$ & $28.3 \%$ & $15.7 \%$ & $7.4 \%$ & $2.6 \%$ & $37.4 \%$ \\
\hline GHS2006 & $68.8 \%$ & $61.2 \%$ & $56.5 \%$ & $52.1 \%$ & $46.8 \%$ & $34.8 \%$ & $27.2 \%$ & $15.4 \%$ & $7.2 \%$ & $6.0 \%$ & $39.5 \%$ \\
\hline
\end{tabular}

Figure 19

Child support grant take-up by earnings levels (2002-2006)

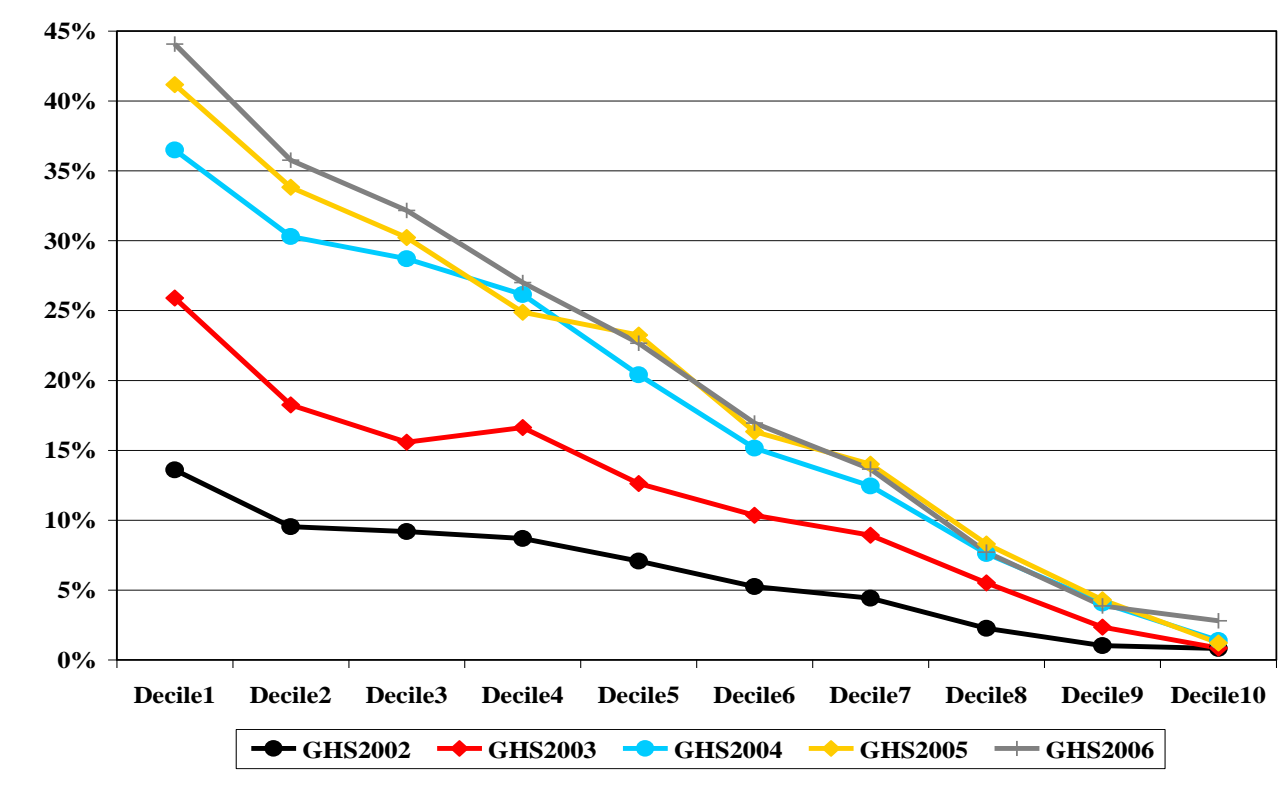

Source: Statistics South Africa General household surveys

\section{5(h) Incentive effects of the CSG}

Little research has thus far been conducted on the impact of the CSG, both on poverty and on behaviour, yet the latter aspect in particular has generated heated public debate, with some people arguing that the CSG increases fertility. It is not possible to draw strong conclusions on this, yet a descriptive analysis of potential behavioural effects can perhaps be useful. These effects can potentially be categorised into its impact on the following related aspects:

- Fertility

- Household composition or formation, and thus also migration.

The first of these is undoubtedly the potential impact that receives most public attention. Little evidence, apart from anecdotal evidence, has been presented to support such a view.

Economists would argue that incentives matter, and that the CSG changes incentives for having children. Yet, at the same time, as supporters of the CSG often 
argue, R230 per month (the present value of the grant) is a rather small benefit to be gained for having a child, compared to the additional costs that a child brings. It is only amongst the very poor, mainly in rural areas, where it is possible that the benefits could be seen to outweigh the costs. On the other hand, incentives matter at the margin: It is likely that there are some people for whom the additional benefits of having a child may make it less unattractive than it may otherwise have been. To use some of the anecdotal examples, for a teenage girl in poor circumstances in rural areas, the fact that such a grant exists may have an influence on how careful she is to avoid pregnancy. This alteration in incentives is thus likely to have some positive impact on fertility, as critics argue. But how large would such an effect be, and how widespread? It is likely that only a relatively small number of people would be in such a situation where a small grant would alter their behaviour in such a manner. Were the grant large (say ten times as large), a different scenario might have arisen (yet examples of where governments have tried to stimulate fertility in some developed countries have shown that it is very difficult to do so even by offering large incentives; other factors than only costs and benefits seem to enter these behaviours). There has been no clear evidence of fertility increases, or a reduction of the age of first conception, to support the view that the CSG has increased fertility; it may at most have succeeded in slightly slowing the rate of decline of fertility compared to what it would have been.

It is well established that, in South African circumstances, households form around income. The large old age pension has had a particularly strong effect in this regard in rural areas. Many studies indicate that household formation and composition are endogenous, i.e. that the social grant system affects the formation and composition of households (see e.g. Klasen and Woolard, 2009). Little of this research has yet been conducted on the impact of the CSG, but it is likely to have had some effect on household structure, even though the individual benefit is less than a quarter of that of the social pension. Posel et al (2003) argue that the CSG provides rural women with the capital to migrate to urban areas in search of jobs. On the other hand, it is not certain whether the existence of the CSG encourages mothers who do migrate to keep their children with them rather than to leave them with relatives in rural areas. Nor is it clear which would be better for the child, as being with the mother in urban areas would only be an improvement if good care facilities or other options are available.

\section{$6 \quad$ CONCLUSION}

This paper confirms that South Africa has a well-developed social assistance system that is exceptionally large by middle-income country standards. South Africa's social grants are very well targeted and have a significant mitigating impact on poverty. Considerable uncertainty remains about some of the incentive effects of these grants, but it is becoming increasingly clear that they influence the behaviour of recipients and potential recipients in variety of ways, not all of which are necessarily benign. The emergence of firm evidence, or even sufficiently strong perceptions, of widespread perverse incentives resulting from social assistance schemes may raise the attractiveness to South African decision makers of programmes such as workfare and conditional cash transfers. In other countries, such programmes have shown promising signs of the ability to simultaneously alleviate poverty and incentivise desired behaviour. Important aspects of their longer-term impacts remain unclear, 
however, and their applicability in South Africa would depend crucially on contextual factors such as the availability of work opportunities for workfare participants and the ability of educational and health care institutions to participate effectively in conditional cash transfer programmes. There is much scope for further research on the potential of these and other innovative social assistance schemes in the South African context.

\section{REFERENCES}

Armstrong, P., B. Lekezwa \& F.K. Siebrits (2008): Poverty in South Africa: a profile based on recent household surveys. Stellenbosch Economic Working Papers No 04/08. Stellenbosch: University of Stellenbosch (Department of Economics \& Bureau for Economic Research).

Becker, G.S. (1981): A treatise on the family. Chicago: University of Chicago Press.

Bertrand, M., D. Miller and S. Mullainathan (2003): Public policy and extended families: evidence from pensions in South Africa. World Bank Economic Review, 17(1): 27-50.

Black, P.A. (2004): Poverty at the household level: a review of theory and South African evidence. South African Journal of Economics, 72(3): 413-434.

Blank, R. (2004): What did the 1990s welfare reform accomplish? Paper prepared for the Berkeley Symposium on Poverty and Demographics, the Distribution of Income, and Public Policy. Michigan, University of Michigan (Gerald R Ford School of Public Policy).

Brand, D. (2005): Introduction to socio-economic rights in the South African Constitution. In C. Heyns and D. Brand (Eds.): Socio-economic rights in South Africa. Pretoria: Pretoria University Law Press: 1-56.

Britto, T. (2005): Recent trends in the development agenda of Latin America: an analysis of conditional cash transfers. Brasilia: Ministry of Social Development.

Community Agency for Social Enquiry (CASE) (2000): Phasing in the Child Support Grant: a social impact study. Study prepared for the Department of Welfare. Case, A. (2000): Health, income and economic development. Paper delivered at the Annual World Bank Conference on Development Economics held in Washington DC on 1-2 May 2001.

Community Agency for Social Enquiry (CASE) (2005) Investigation into the increase in uptake of disability and care dependency grants since December 2001. Report commissioned by the National Treasury and the Department of Social Development. Pretoria.

Case, A. and A. Deaton (1996): Large cash transfers to the elderly in South Africa. NBER Working Paper No 5572. Cambridge, MA: National Bureau for Economic Research.

Case, A., I-Fin. Lin and S. McLanahan (1999): How hungry is the selfish gene? NBER Working Paper No 7401. Cambridge, MA: National Bureau for Economic Research.

Davis, D.M. (2006): Adjudicating the socioeconomic rights in the South African constitution: towards "deference lite"? South African Journal on Human Rights, 22: 301-327.

De Neubourg, C., J. Castonguay and K. Roelen (2007): Social safety nets and targeted social assistance: lessons from the European experience. Social Protection Discussion Paper No. 718. Washington DC: World Bank. 
Department of Social Development (2006): Report on incentive structures of social assistance grants in South Africa. Pretoria.

Department of Welfare (1997): White paper for social welfare. Pretoria: Department of Welfare.

Dinkelman, T. (2004): How household context affects search outcomes of the unemployed in Kwazulu-Natal, South Africa: a panel data analysis. South African Journal of Economics, 72(3): 484-521.

Donaldson, A.R. (2007): Income security, retirement reform and social development. Paper delivered at a Bureau for Economic Research Conference in Sandton on 17 May 2007.

Duflo, E. (2003): Grandmothers and granddaughters: old-age pensions and intrahousehold allocation in South Africa. World Bank Economic Review, 17(1): 1-25.

Edmonds, E., K. Mammen and D. Miller (2001): Rearranging the family? Household composition responses to large pension receipts. Mimeographed. Hanover, $\mathrm{NH}$ : Dartmouth College (Department of Economics).

International Labour Organisation (2000): World labour report 2000. Geneva: International Labour Organisation.

Kingdon, G. and J. Knight (2000): Are searching and non-searching unemployment distinct states when unemployment is high? The case of South Africa. CSAE Working Paper 2000-2. Oxford: Oxford University (Centre for the Study of African Economies).

Kingdon, G. and J. Knight (2004); Unemployment in South Africa: the nature of the beast. World Development, 32(3): 391-408.

Kildal, N. (2001): Workfare tendencies in Scandinavian welfare policies. Unpublished paper. Geneva: International Labour Office.

Klasen, S. and I. Woolard (2009): Surviving unemployment without state support: unemployment and household formation in South Africa. Journal of African Economies, 18(1): 1-51.

Leibbrandt, M., I. Woolard and H. Bhorat (2001): Introduction. In H. Bhorat, M. Leibbrandt, M. Maziya, S Van der Berg and I. Woolard (Eds,): Fighting poverty: labour markets and inequality in South Africa. Cape Town: UCT Press: 1-20.

Lund, F.J. (1993): State social benefits in South Africa. International Social Security Review, 46(1): 5-25.

Lund, F.J. (1998): Social assistance. Unpublished paper prepared for the Social Policy Project of the Centre for Development and Enterprise. Johannesburg.

Lund, F.J. (2006): Gender and social security in South Africa. In V. Padayachee (Ed.): The Development Decade? South Africa, 1994-2004. Cape Town: HSRC Press: 160-179.

Naicker P. (2005): The audit report on services to children in South Africa. Pretoria: Department of Social Development.

National Treasury (2007a): Social security and retirement reform. Second discussion paper. Pretoria: National Treasury.

National Treasury (2007b): Estimates of national expenditure 2007. Pretoria: National Treasury.

National Treasury (2008): Estimates of national expenditure 2008. Pretoria: National Treasury.

National Treasury (various issues): Budget review. Pretoria: National Treasury. 
Nattrass, N. (2006a): Trading off income and health? Aids and the disability grant in South Africa. Journal of Social Policy, 35: 3-19.

Nattrass, N. (2006b). Disability and welfare in South Africa's era of unemployment and Aids. CSSR Working Paper No. 147. Cape Town: University of Cape Town (Centre for Social Science Research).

Ochel, W. (2006): Welfare-to-work experiences with specific work-first programmes in selected countries. International Social Security Review 58(4): 67-93.

Pauw, K. and L. Mncube (2007): Expanding the social security net in South Africa: opportunities, challenges and constraints. DPRU Working Paper No. 07/127. Cape Town: University of Cape Town (Development Policy Research Unit).

Pillay, A. (2007): In defence of reasonableness: giving effect to socio-economic rights. Economic and Social Rights Review, 8(4): 3-8.

Posel, D., J.A. Fairburn and F. Lund (2006): Labour migration and households: a reconsideration of the effects of the social pension on labour supply in South Africa. Economic Modelling, 23: 836-853.

Rakoloti, T. (2008): Update on social assistance regulations. Presentation to the Portfolio Committee on Social Development. Cape Town: 25 June 2008.

Rawlings, L. and G. Rubio (2005): Evaluating the impact of Conditional Cash Transfer Programmes. World Bank Research Observer 20(1): 29-55.

Samson, M., D. Rosenblum, C. Haarmann, D. Haarmann, K. MacQuene and I. van Niekerk (2001): The socio-economic impact of "workfare": welfare reform lessons from the United States and other international experiences. Research Paper No 26. Cape Town: Economic Policy Research Institute.

Skweyiya, Z. (2008): Budget vote speech of the Minister of Social Development. Cape Town, 30 May 2008.

Smith Committee (2005): Report of the Committee on strategy and policy review retirement provision in South Africa. Pretoria: Department of Finance.

South African Human Rights Commission (2006): Sixth economic and social rights report. Johannesburg: Shereno Printers.

South African Reserve Bank (various issues): Quarterly bulletin. Pretoria: SARB.

Statistics South Africa (2008a): Income and expenditure survey 2006.Pretoria.

Statistics South Africa (2008b): Quarterly labour force survey (first and second quarter 2008). Pretoria.

Tabor, S.R. (2002): Assisting the poor with cash: design and implementation of social transfer programs. Social Protection Discussion Paper No. 223. Washington DC: World Bank

Tesliuc, E. (2005): Social safety nets in OECD countries. Social Safety Nets Primer Notes No 25. Washington DC: The World Bank.

Townsend, P. (2007): The right to social security and national development lessons from OECD experience for low-income countries. Issues In Social Protection Discussion Paper No 18. Geneva: International Labour Organisation.

Triegaardt, J. (2005): The Child Support Grant in South Africa: a social policy for poverty alleviation? International Journal of Social Welfare, 14: 249-255.

Van der Berg, S. (1997): South African social security under apartheid and beyond. Development Southern Africa, 14(4): 481-501.

Van der Berg, S. (2001): Social policy to address poverty. In H. Bhorat, M. Leibbrandt, M. Maziya, S. Van der Berg and I. Woolard (Eds.): Fighting poverty: labour markets and inequality in South Africa. Cape Town: UCT Press: 171204. 
Van der Berg, S. (2002): Issues in South African social security. Stellenbosch Economic Working Papers No 01/02. Stellenbosch: University of Stellenbosch (Department of Economics \& Bureau for Economic Research).

Van der Berg, S., M. Louw and L. du Toit (2007): Poverty trends since the transition: what we know. Stellenbosch: University of Stellenbosch (Department of Economics).

Van der Berg, S, M. Louw and D. Yu (2008): Post-transition poverty trends based on an alternative data source. South African Journal of Economics, 76(1): 58-76.

Vorster, J.H., H.M. Rossouw and G.J. Muller (2000): Phasing out the state maintenance grant within the context of developmental social welfare. Stellenbosch: University of Stellenbosch (Datadesk, Department of Sociology).

Vorster, J.H., I. Eigelaar-Meets, C. Poole and H.M. Rossouw (2004): A profile of social security beneficiaries in selected districts in the Western Cape. Stellenbosch: University of Stellenbosch (Department of Sociology).

Walker, R. (2005): Social security and welfare. Maidenhead: Open University Press. 